\title{
Methane Seepage on Mars: Where to Look and Why
}

\author{
Dorothy Z. Oehler ${ }^{1}$ and Giuseppe Etiope ${ }^{2}$
}

\begin{abstract}
Methane on Mars is a topic of special interest because of its potential association with microbial life. The variable detections of methane by the Curiosity rover, orbiters, and terrestrial telescopes, coupled with methane's short lifetime in the martian atmosphere, may imply an active gas source in the planet's subsurface, with migration and surface emission processes similar to those known on Earth as "gas seepage." Here, we review the variety of subsurface processes that could result in methane seepage on Mars. Such methane could originate from abiotic chemical reactions, thermogenic alteration of abiotic or biotic organic matter, and ancient or extant microbial metabolism. These processes can occur over a wide range of temperatures, in both sedimentary and igneous rocks, and together they enhance the possibility that significant amounts of methane could have formed on early Mars. Methane seepage to the surface would occur preferentially along faults and fractures, through focused macro-seeps and/or diffuse microseepage exhalations. Our work highlights the types of features on Mars that could be associated with methane release, including mud-volcano-like mounds in Acidalia or Utopia; proposed ancient springs in Gusev Crater, Arabia Terra, and Valles Marineris; and rims of large impact craters. These could have been locations of past macro-seeps and may still emit methane today. Microseepage could occur through faults along the dichotomy or fractures such as those at Nili Fossae, Cerberus Fossae, the Argyre impact, and those produced in serpentinized rocks. Martian microseepage would be extremely difficult to detect remotely yet could constitute a significant gas source. We emphasize that the most definitive detection of methane seepage from different release candidates would be best provided by measurements performed in the ground or at the ground-atmosphere interface by landers or rovers and that the technology for such detection is currently available. Key Words: Mars-Methane-Seepage-Clathrate-Fischer-Tropsch-Serpentinization. Astrobiology 17, 1233-1264.
\end{abstract}

\section{Introduction}

$\mathbf{T}$ HE EXISTENCE OF METHANE $\left(\mathrm{CH}_{4}\right)$ on Mars is a topic of primary interest in planetary exploration because of its potential link to microbial metabolic activity. Methane can be generated by, and can provide energy (as an electron donor) to, microbial communities (e.g., Schulte et al., 2006). Methane, like other gases that can be produced in deep rocks, can also be a proxy for dynamic geologic and subsurface fluidcirculation processes.

Spatially and temporally varying $\mathrm{CH}_{4}$, with concentrations ranging from 0.2 to $60 \mathrm{ppbv}$, has been detected in the martian atmosphere by the Curiosity rover in Gale Crater and by previous orbiter and Earth-based telescopic observations (e.g., Mumma et al., 2009; Fonti and Marzo, 2010; Geminale et al., 2011; Webster et al., 2015, 2016; RoosSerote et al., 2016). Methane was also reported in martian meteorites (e.g., Blamey et al., 2015). The fact that $\mathrm{CH}_{4}$ is estimated to have a relatively short lifetime in the martian atmosphere (about 300 years but potentially as short as 200 days or even a few hours near the surface; Lefèvre and Forget, 2009), coupled with its varying abundance, may imply an active gas source in the planet's subsurface that periodically releases $\mathrm{CH}_{4}$ to the atmosphere. Methane could be generated in trace amounts above the martian surface (possibly due to electrical discharges near iced ground

\footnotetext{
${ }^{1}$ Planetary Science Institute, Tucson, Arizona, USA.

${ }^{2}$ Istituto Nazionale di Geofisica e Vulcanologia, Sezione Roma 2, Roma, Italy, and Faculty of Environmental Science and Engineering, Babes-Bolyai University, Cluj-Napoca, Romania.

(C) Dorothy Z. Oehler and Giuseppe Etiope, 2017; Published by Mary Ann Liebert, Inc. This Open Access article is distributed under the terms of the Creative Commons Attribution Noncommercial License (http://creativecommons.org/licenses/by-nc/4.0/) which permits any noncommercial use, distribution, and reproduction in any medium, provided the original author(s) and the source are credited.
} 
[Robledo-Martinez et al., 2012] or UV irradiation [Section 3.2.4]), but as is the case on Earth, larger amounts could be produced in the martian subsurface by a wide array of gas generation processes. Subsurface sources could be releasing either present-day methane or methane formed in the past and subsequently stored in clathrates, zeolites, or reservoirquality rocks trapped below sealing lithologies. The possibility of active subsurface sources of martian $\mathrm{CH}_{4}$ implies the existence of a gas migration process known on Earth as "gas seepage." Accordingly, in this paper, we concentrate on the subsurface mechanisms that could account for martian $\mathrm{CH}_{4}$, including its generation, storage, and seepage to the surface, as well as the likely physical manifestations of that seepage on the surface of the planet.

We address these processes in detail, as some readers may be unfamiliar with the extensive body of knowledge of subsurface $\mathrm{CH}_{4}$ generation and migration from the petroleum industry or the in-depth information on terrestrial methane seeps accumulated from decades of studies. For example, because $\mathrm{CH}_{4}$ content is low in volcanic emissions, some have concluded that a geologic $\mathrm{CH}_{4}$ source would not be important for Mars (e.g., Krasnopolsky, 2005). Such conclusions neglect the array of geologic processes that could produce $\mathrm{CH}_{4}$ on Mars. Similarly, clathrates occasionally have been misconceived as potential origins for martian methane. Yet clathrates are only a storage mechanism for $\mathrm{CH}_{4}$, and the question of the derivation of that $\mathrm{CH}_{4}$ remains. Here, we address the scope of potential $\mathrm{CH}_{4}$ generation processes for Mars, including some processes not generally recognized, and we clarify details of serpentinization and Fischer-Tropsch-type (FTT) reactions. We further discuss criteria for trapping or storing subsurface $\mathrm{CH}_{4}$ on Mars as well as factors that could control $\mathrm{CH}_{4}$ seepage to the martian surface, the types of surface manifestations that might reflect that seepage, and whether seepage could account for the various $\mathrm{CH}_{4}$ detections on Mars. We conclude by combining all the above to identify sites or regions on Mars that may be prime candidates for methane release and may be priority targets for orbital scans (such as by the ExoMars Trace Gas Orbiter) and for landed, ground-based analysis (using optimum seepage-detection methods) in future missions.

This work is divided into the following Sections:

- Section 2: Gas seepage fundamentals (definitions, mechanisms, surface manifestations, and fluxes on Earth)

- Section 3: Methane generation mechanisms

- Section 4: Potential sites and timing of methane generation on Mars

- Section 5: Potential sites of methane accumulation on Mars

- Section 6: Seepage pathways on Mars (from sites of generation or accumulation to the surface)

- Section 7: Potential sites of methane seepage on Mars

- Section 8: Can seepage fluxes support observed atmospheric $\mathrm{CH}_{4}$ concentrations?

- Section 9: How to detect gas seepage on Mars (optimum methods)

- Section 10: Summary and Conclusions

Introductory figures include Fig. 1, a schematic illustration of potential methane origins and seepage on Mars; Fig. 2, illustrations of key global features discussed; and Fig. 3, a global map showing locations of figures in this paper.

\section{Gas Seepage Fundamentals}

\subsection{Definitions and mechanisms}

In Earth sciences, the term "gas seepage" is used to indicate a steady or episodic, slow or rapid flow of gaseous hydrocarbons from subsurface sources to the surface (Etiope, 2015). In the petroleum geochemistry literature, the term "seepage" refers to hydrocarbon fluids, gas, and oil, where gases are composed mainly of methane, with subordinate amounts of heavier alkanes (ethane, propane, and butane). These gases are formed in sedimentary rocks mainly through decomposition (microbial or thermogenic) of organic matter. "Seepage" has also been used with reference to exhalations of abiotic methane formed in igneous (ultramafic) serpentinized rocks (e.g., Etiope, 2015; Etiope et al., 2016), through inorganic reactions such as FTT synthesis (e.g., Etiope and Sherwood Lollar, 2013).

Detailed description and classification of gas seepage processes on Earth, as well as their implications for resource exploration, atmospheric greenhouse gas budget, and the environment, are reported in a wide body of literature (e.g., Link, 1952; Hovland and Judd, 1988; Kopf, 2002; Etiope et al., 2009; Etiope and Klusman, 2010; Etiope, 2015; Mazzini and Etiope, 2017, and references therein). Terrestrial gas seepage does not refer to geothermal or volcanic $\mathrm{H}_{2} \mathrm{O}$ - or $\mathrm{CO}_{2}$-rich gas manifestations (e.g., fumaroles, mofettes, and geysers) where hydrocarbons are a minor component. Accordingly, we do not use the term "seepage" for volcanic emissions, although we discuss this form of degassing. Like terrestrial seepage, and according to the general theory of gas migration in geologic media (e.g., MacElvain, 1969; Malmqvist and Kristiansson, 1985; Brown, 2000; Etiope and Martinelli, 2002), methane in subsurface martian rocks should move preferably via advection, that is, in flow driven by pressure gradients and controlled by permeability (Darcy's law). Diffusion, the slow motion of gas molecules driven by concentration gradients (Fick's law), is important only at small scales, in low-permeability porous media and over long geologic time scales. Modeling studies have also suggested that diffusion cannot explain the methane plumes and concentration variations observed on Mars (Stevens et al., 2015, 2017). On Earth, pressurized gas can occur in both fine-grained rocks and in coarse-grained, reservoir rocks (which are porous and permeable and sealed by impermeable strata such as shales, permafrost, and salt). Reservoir rocks host gas produced in source rocks (or the "kitchen" as used in petroleum literature). Subsequent gas seepage can start from either gas-rich, fine-grained source rocks or, more frequently, from pressurized reservoirs. Seepage occurs preferentially through permeable pathways, such as faults and fractures and in breaches in sealing lithologies. Therefore, for understanding potential gas seepage on Mars, it is important to distinguish three main components: (a) gas generation sources, (b) pathways from sources at depth to the surface (gas migration routes), and (c) potential surface manifestations of that gas seepage.

We believe, then, that it is opportune to clarify the difference between the origin of methane and the source of methane. Origin refers to its biotic or abiotic derivation, the genetic mechanism by which the methane is produced: 


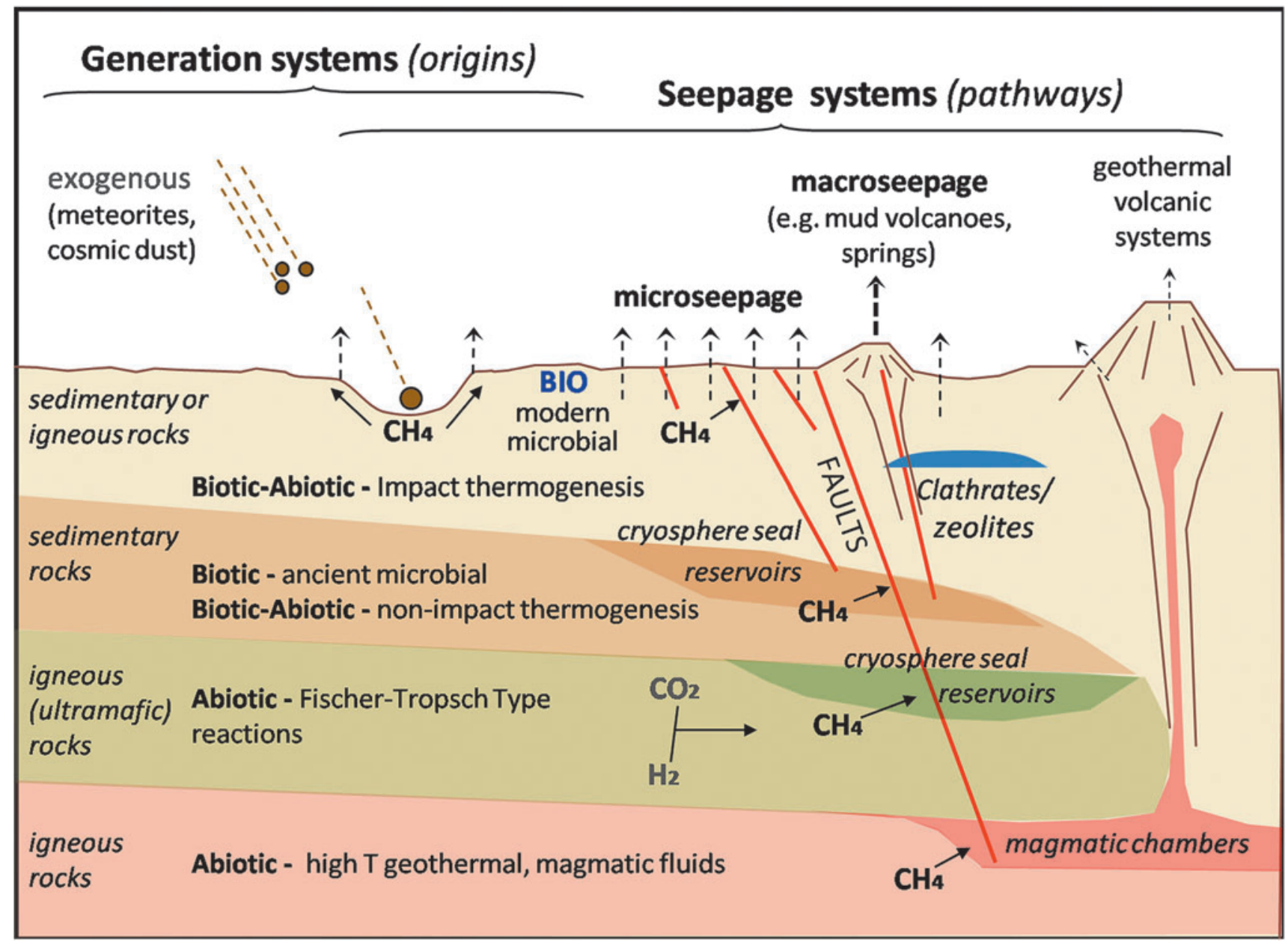

FIG. 1. Schematic illustration of potential methane origins and seepage on Mars. Biotic methane from present-day microbial activity may only occur in the subsurface, even at great depths (shown near surface only for graphical reasons), and the gas may use faults and fractured rocks for exhalation to the surface. Geologic methane, not involving living organisms, includes abiotic processes and generation from ancient organic material of biotic derivation, either in sedimentary or igneous rocks (see text). $\mathrm{CO}_{2}$ and $\mathrm{H}_{2}$ (methane precursors in FTT reactions) can derive from C-bearing rocks, atmosphere-rock interactions, magmatic fluids, serpentinization (olivine hydration), radiolysis, and silicate cataclasis. Methane can be generated also in organic-rich source rocks and may accumulate in permeable/porous reservoir rocks. Temporary reservoirs, like clathrates, may host any type of methane. Irrespective of origin, gas generally migrates along faults or permeable layers and exhales to the surface through focused macro-seeps or diffuse microseepage. Volcanoes, as on Earth, may be very minor methane emitters. While this image highlights that gas seepage stems mainly from gas reservoirs or accumulations, in some cases gas may migrate to the surface directly from source rocks, if there are preferential pathways (faults, fractures) for degassing. Spatial scales of the surface manifestations are described in the text.

biotic $\mathrm{CH}_{4}$ is the methane formed from biotic organic precursors (such as kerogen) and/or from the action of microbial processes; abiotic $\mathrm{CH}_{4}$ is the methane formed from abiotic precursors (such as meteoritic organics or $\mathrm{CO}_{2}$ ) and where the conversion to $\mathrm{CH}_{4}$ is not driven by microbes. Source refers to the loci from which methane starts its seepage journey to the surface and atmosphere, which may correspond, as noted above, to the rocks/sediments where gas originated (source rocks) or accumulated (reservoir rocks).

\subsection{Gas seepage on Earth}

Gas seepage on Earth can produce a variety of visible, morphological structures, cumulatively called "macro-seeps."
They include circular depressions or small mounds with venting gas, mud volcanoes, water springs with gas bubbling or high concentrations of dissolved gas. In addition, gas seepage may be in the form of diffuse exhalations from the ground (microseepage), without any specific morphological structure. A wide body of literature exists on gas seepage on Earth (e.g., Macgregor, 1993; Klusman et al. 2000; Abrams, 2005; Etiope et al., 2009; Etiope, 2015). Here, we will review only the main concepts that can be useful for understanding potential seepage on Mars.

2.2.1. Macro-seeps. Macro-seeps (or seeps) are "channeled" flows of gas, typically associated with fault systems and morphological surface expression. The exact global number of seeps on Earth is unknown but appears to exceed 10,000 on 

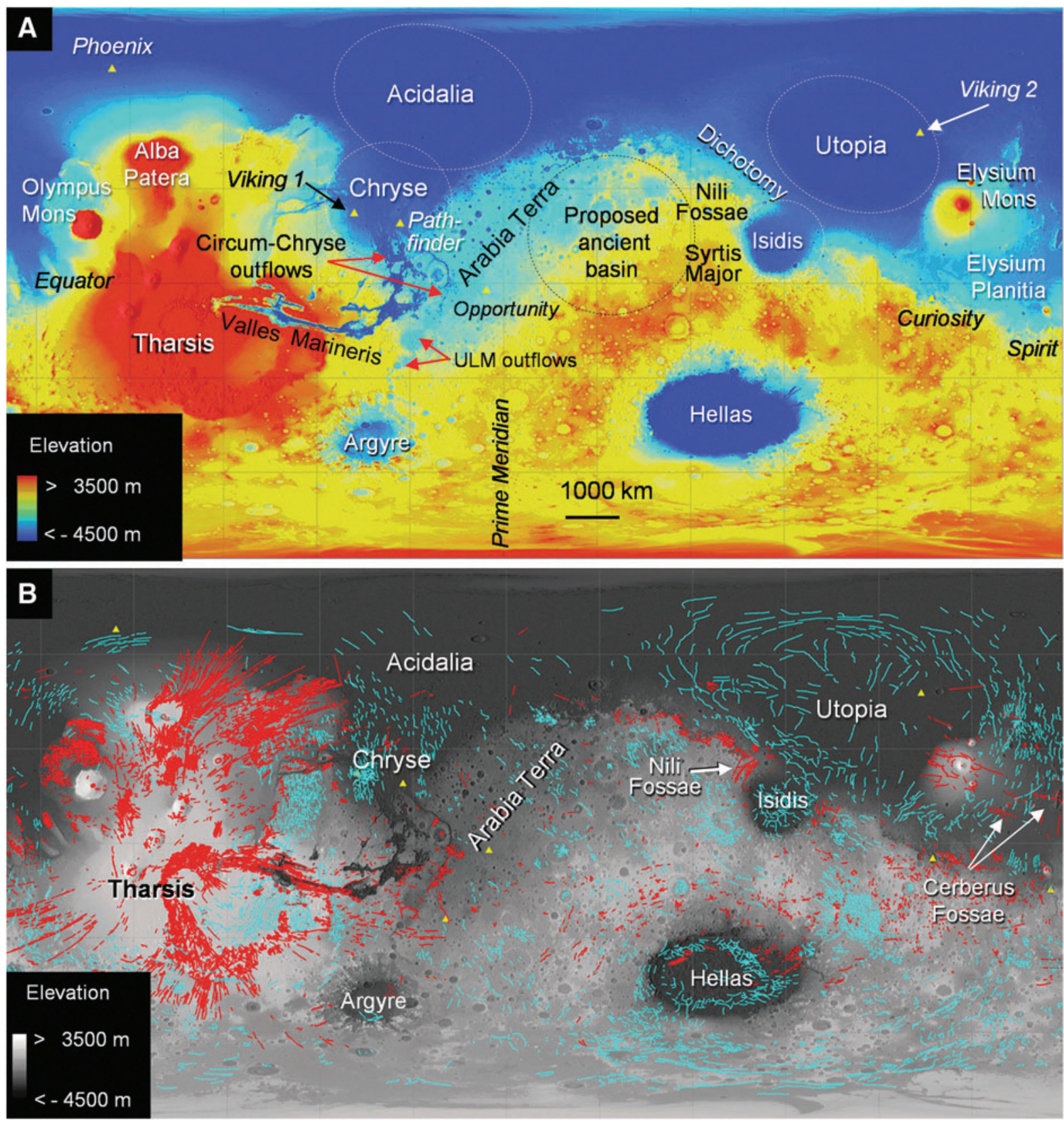

FIG. 2. Major features on near-global map of Mars. (A) Basemap of topography from Mars Orbiter Laser Altimeter (MOLA) data, equirectangular projection. Grid spacing, $30^{\circ}$. Yellow triangles, landing sites of rovers or landers. White dashed circles, approximate locations of major QCDs in the lowlands (after Frey, 2008). Black dashed circle, proposed ancient basin in Arabia Terra (Dohm et al., 2007). ULM outflows, Uzboi-Ladon-Morava system of ponded water and outflows (Irwin and Grant, 2013). MOLA basemap from Mars Global GIS DVD version 2.1. Image credit: USGS; NASA/ JPL-Caltech/GSFC. (B) Major faults. These may provide long-lived and deep conduits for seeping fluids. Same basemap, projection, and landing site symbols as in (A), with elevation shown in grayscale to emphasize faults. Extensional faults (red) and compressional faults (blue-green), from Knapmeyer et al. (2006) in the USGS Mars Global GIS DVD version 2.1. Key features only are shown to enhance visibility of the faults.

land alone, distributed throughout petroliferous basins (Etiope, 2015). Depending on the fluid phase and subsurface geologic setting, seeps can be simple "gas-phase" vents (gas seeps); gas associated with oil seeps; emissions of gas, water, and mud (mud volcanoes); and gas-rich water springs.

Gas seeps may vent from outcropping rocks, through the soil horizon, or through river/lake beds, and may manifest with strong odor, an absence of vegetation, wet bubbly ground, abnormal snowmelt patterns, and soil temperature anomalies. The gas is primarily generated by thermal degradation of biogenic kerogen or oil, with lesser contributions from gas generated by ancient microbes (Etiope, 2015). Abiotic gas seeps are known in serpentinized ultramafic rocks (peridotites), such as the Chimaera fires in Turkey and Los Fuegos Eternos in the Philippines (Etiope and Schoell, 2014, and references therein). 


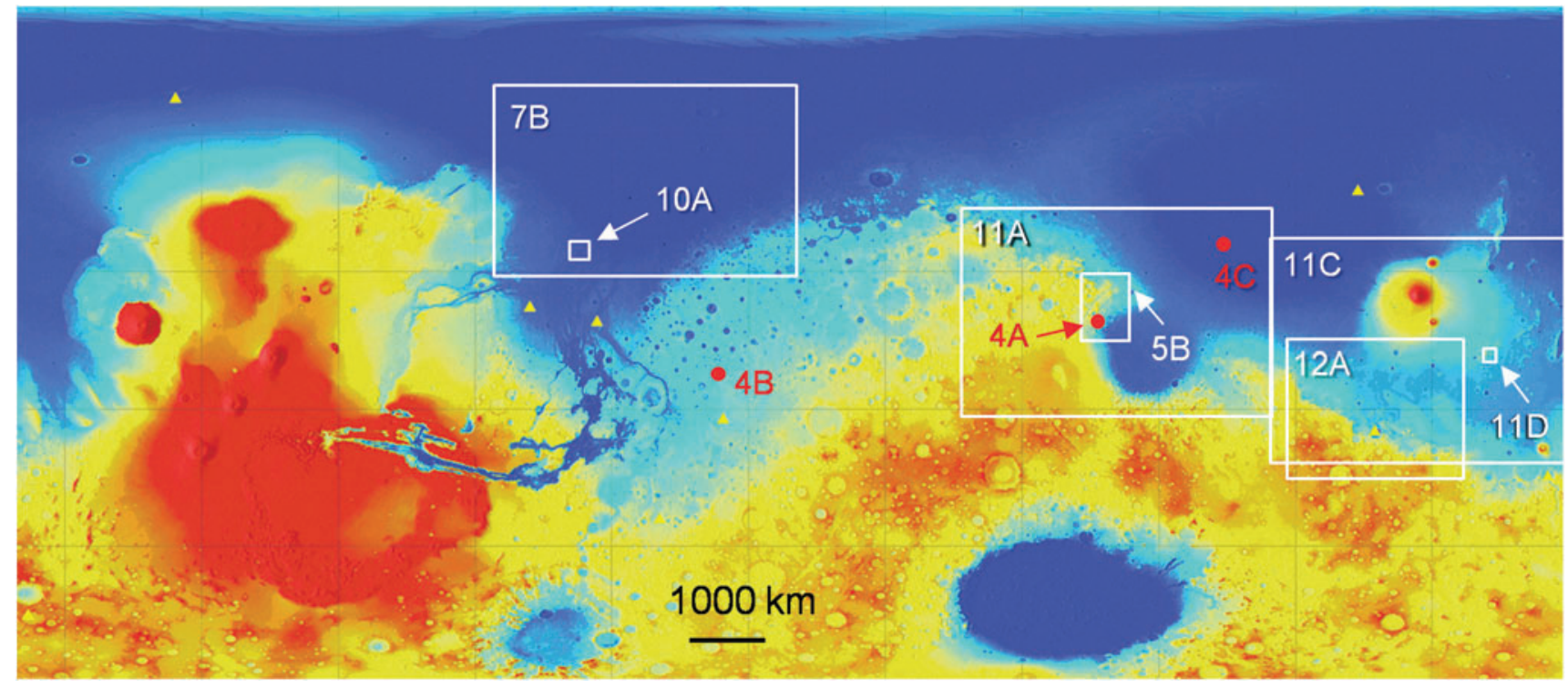

FIG. 3. Location map. Basemap and landing sites as in Fig. 2A. Rectangles show locations of figures in this paper. Red dots are locations of images too small to show as rectangles.

Mud volcanoes are the largest expression of methane release into the atmosphere. These cone-shaped structures are produced over faults by advective up-welling of sediments (mud), fluidized by gas and water. Mud volcanism refers to "sedimentary volcanism" (not to be confused with magmatic volcanism). It represents an ensemble of subsurface movements of large masses of sediments and fluids, triggered by gravitational instabilities of low-density sediments that result from rapid sedimentation and overpressure and lead to formation of mobile shales, diapirs, diatremes, and mud intrusions (e.g., Kopf, 2002; Mazzini and Etiope, 2017). The gas released by most mud volcanoes is that which previously accumulated in reservoirs (and interacted with the mobile shales). This gas is nearly always thermogenic methane (and on Earth this is biotic; Etiope et al., 2009), but in a few cases it can be dominated by $\mathrm{CO}_{2}$ and $\mathrm{N}_{2}$ where hydrocarbon systems are located close to geothermal areas or are related to the final stages of natural gas generation (Etiope, 2015, and references therein). The gas can be released through continuous (steady-state) exhalations from craters, vents, and surrounding soil, intermittent blow-outs, and eruptions (Etiope and Milkov, 2004; Mazzini and Etiope, 2017, and references therein). Mud volcanoes releasing abiotic methane are not known on Earth. Mud volcanism is a process that has likely occurred on Mars, as discussed in Section 7.1.1.

Gas-rich springs of mineral waters and artesian aquifers may release an abundant gaseous phase to the atmosphere (Etiope, 2015). Water may have a deep origin and may have interacted with gas during its ascent to the surface. Mineralwater springs have often been neglected as a vehicle for releasing hydrocarbons from subsurface accumulations, and few data (detailing concentrations and/or degassing fluxes) for dissolved gases are available. Recent studies have revealed the existence of many springs, in at least 16 countries, issuing from serpentinized peridotites, with abundant concentrations of abiotic methane (see reviews in Etiope and Sherwood Lollar, 2013; Etiope and Schoell, 2014). These springs are typically hyperalkaline, with $\mathrm{pH}>9$, due to active serpentinization processes (Etiope et al., 2016, and references therein).

2.2.2. Microseepage. Microseepage is the slow, widespread exhalation of gas through rocks, throughout relatively large areas, conceptually independent from macro-seeps, but enhanced along faults (e.g., Brown, 2000; Etiope and Klusman, 2010). The seepage magnitude is small enough to require instrumentation to detect. Like macro-seeps, microseepage on Earth is common in association with gas-oil fields; it was widely used, in fact, as an exploration tool to discover natural gas and oil reservoirs at depth. Microseepage flux may vary over time, depending on variations of gas pressures along the subsurface migration pathway or on seasonal changes in the soil, where bacterial methanotrophic activity may consume methane (especially in warmer periods). Seasonality in the flux rates is also apparent in climates where the soils freeze to a depth of $30-60 \mathrm{~cm}$.

2.2.3. Methane seepage fluxes. In general, the $\mathrm{CH}_{4}$ flux from macro-seeps is orders of magnitude greater than that from microseepage. For macro-seeps, it is important to note that the exhalation of $\mathrm{CH}_{4}$ does not occur exclusively from the visible vents or craters. There is, in fact, a halo of seepage with no physical manifestations, called miniseepage (e.g., Etiope, 2015), which surrounds the channeled seep. This is a transition area where gas flux gradually decreases, dropping to "zero," tens or hundreds of meters from the central vent. Because such a transition area can be quite large, the miniseepage exhalation adds an amount of gas to the atmosphere that may be more than three times higher than that released from vents.

Methane flux in gas seeps, either from individual vents or from an entire macro-seepage area (including miniseepage), may span a wide range of values, on the order of $10^{1}$ to $10^{3}$ tonnes year ${ }^{-1}$. The flux from large seeps may exceed $10^{3}$ tonnes year ${ }^{-1}$. For gas vents with a diameter $<1 \mathrm{~m}$, the flux is typically between $10^{-1}$ and $10^{2}$ tonnes year ${ }^{-1}$. 
The single vents or craters of small mud volcanoes (1-5 m high) can release up to tens of tonnes of $\mathrm{CH}_{4}$ per year. An entire mud volcano, hosting tens or hundreds of vents, can continuously emit hundreds or thousands (from giant mud volcanoes) of tonnes of $\mathrm{CH}_{4}$ per year; eruptions from mud volcanoes could release thousands of tonnes of $\mathrm{CH}_{4}$ within a few hours. In all mud volcano areas measured to date (Italy, Romania, Azerbaijan, Japan, and Taiwan), the specific flux, including vents and miniseepage (excluding eruptions), was between $10^{2}$ and $10^{4}$ tonnes $\mathrm{km}^{-2}$ year ${ }^{-1}$, with a global average of 3150 tonnes $\mathrm{km}^{-2}$ year ${ }^{-1}$ (Etiope et al., 2011a).

Microseepage $\mathrm{CH}_{4}$ flux values range from about 1 to several $10^{3}$ tonnes $\mathrm{km}^{-2}$ year ${ }^{-1}$, with a global mean around 4 tonnes $\mathrm{km}^{-2}$ year $^{-1}$ (Etiope and Klusman, 2010; Etiope, 2015). However, since microseepage is widespread throughout vast sedimentary areas, its global output to the atmosphere was estimated to be higher $\left(\sim 10-25\right.$ million tonnes year $\left.{ }^{-1}\right)$ than that from gas seeps $\left(\sim 3-4\right.$ million tonnes year $\left.{ }^{-1}\right)$ and mud volcanoes (likely $<10-20$ million tonnes year $^{-1}$; Etiope and Klusman, 2010; Etiope, 2015).

\section{Methane Generation Mechanisms}

Methane on Mars can potentially derive from both subsurface (geologic or biologic) processes and exogenous processes (transport by interstellar dust and meteorites), as summarized in Fig. 1. Here, we concentrate on subsurface processes and distinguish gas origins (the production systems) from methane storage and methane seepage systems, which are often confused. Methane origin has been considered in previous studies (e.g., Oze and Sharma, 2005; Atreya et al., 2007; Oze et al., 2012), but we add new concepts of thermogenesis of both abiotic and potentially biotic organics. We also discuss the possibility that subsurface methane could have been produced by ancient methanogenic microbes and that methane of any origin could be stored in sealed traps, clathrates, or zeolites. And finally, we clarify details of serpentinization (which does not produce methane) and the origin of methane by FTT reactions after serpentinization.

The generation processes include the following:

Biologic production

(1) Modern microbial activity (by living methanogens)

Geologic production (processes not involving living microbes)

(2) Ancient microbial activity

(3) Thermogenesis of abiotic or potentially biotic organics

(4) FTT (Sabatier) reactions

(5) UV irradiation or ablation-pyrolysis of meteoritic organics

(6) High-temperature geothermal reactions

(7) Magma (volcanic) degassing

\subsection{Modern microbial activity}

On Earth, methane can be formed by methanogenic microbes (anaerobes belonging to the domain Archaea) by $\mathrm{CO}_{2}$-reduction or acetate-fermentation pathways (e.g., Whiticar, 1999), at temperatures from $-11^{\circ} \mathrm{C}$ to more than $100^{\circ} \mathrm{C}$ (Tung et al., 2005; Jablonski et al., 2015). These organisms have been found, in fact, in deep subsurface strata, in permafrost and ice at depths of $\sim 3 \mathrm{~km}$, and in basalts at mid-ocean ridges. They require liquid water, a source of carbon, and $\mathrm{H}_{2}$. The carbon source is commonly $\mathrm{CO}_{2}$, though they can also utilize carbon in acetate, which can itself be a product of bacterial metabolism or thermal cracking of organic material (Wellsbury et al., 1997). On Mars, methanogens could use $\mathrm{CO}_{2}$ from the atmosphere, magmatic fluids, and carbonates, and they could use $\mathrm{H}_{2}$ from serpentinization, radiolysis, cataclasis of silicates, and magmatic degassing (Schulte et al., 2006).

On Mars, the surface is generally thought to be inhospitable to current life (due to extremely low temperatures, high aridity, and high levels of radiation). For example, although data from the Radiation Assessment Detector on the Curiosity rover show surface radiation levels that would be lethal to even dormant examples of the radiation-resistant bacterium, Deinococcus radiodurans, these data also suggest that viable cells might survive in the subsurface below the top meter (Hassler et al., 2014). Thus, potentially extant methanogens are likely to be restricted to the martian subsurface-in endolithic ecosystems within pore spaces of sediment and rock (Boston et al., 1992) and in ice and permafrost (Tung et al., 2005). In these settings, extant methanogens could generate biological methane, and that gas could migrate to the surface along permeable fractures and faults. Calculations for Mars suggest that the $10 \mathrm{ppb}$ methane in the martian atmosphere measured by Krasnopolsky et al. (2004) and Formisano et al. (2004) could be produced by living methanogens in habitats at temperatures of $0^{\circ} \mathrm{C}$ or greater, which, depending on local heat flow and thermal conductivity, could occur at depths from $150 \mathrm{~m}$ to $8 \mathrm{~km}$ (Tung et al., 2005).

\subsection{Geologic production}

3.2.1. Ancient microbial activity. Methane could have been generated by ancient methanogens in subsurface rocks, in past geologic times. This would be analogous to fossil microbial natural gas in petroleum systems on Earth (e.g., Whiticar et al., 1986; Schoell, 1988; Hunt, 1996; Formolo, 2010). Microbial methanogenesis would be expected to have occurred in low-temperature $\left(<100^{\circ} \mathrm{C}\right)$ settings, in rocks with pore spaces sufficient to support endolithic communities, and at depths of a few tens of meters to a few kilometers (McMahon and Parnell, 2014). Sources for $\mathrm{CO}_{2}$ and $\mathrm{H}_{2}$ would be similar to those discussed for modern microbial activity (Section 3.1).

3.2.2. Thermogenesis of abiotic or potentially biotic organics. Methane can be generated by thermal degradation of organic matter resulting from elevated temperatures associated with burial, magmatic heating, hydrothermal systems, and impacts. On Earth, sedimentary organic matter (kerogen) is converted to oil and gas by this process (often called "organic maturation"), dependent mainly on elevated temperature at burial depths. On Mars, this type of origin could involve generation of methane from either abiotic organics (delivered to Mars by meteorites or interplanetary dust particles [IDPs] [Flynn, 1996; Benner et al., 2000; Sephton, 2002; Flynn et al., 2004; Llorca, 2004]) or potentially biotic organics (possible remnants of ancient microbial life that could have existed on early Mars, as it did on the early Earth [Oehler and Allen, 2012a]). Flynn (1996) 
estimated that $\sim 10^{15} \mathrm{~kg}$ of abiotic organic matter could have been delivered to Mars by IDPs, using present-day IDP fluxes. He concluded that this amount is comparable to the terrestrial biomass. But he additionally noted that, since the flux of meteoritic materials onto the surface of Mars was likely much higher in the first half billion years of Solar System evolution, significantly more IDP-sourced, abiotic organic matter may have accumulated on Mars in its earliest history. That material, subsequently, could have been transported and concentrated by fluvial processes on early Mars into the major sedimentary basins (Malin and Edgett, 2000; Carr and Head, 2010; Grotzinger and Milliken, 2012; Grotzinger et al., 2013), where it could have been subjected to thermogenetic alteration (possibly yielding methane) due to burial and magmatic- or impactrelated heating.

The thermal evolution of such martian organic matter would be expected to begin at temperatures above $\sim 60^{\circ} \mathrm{C}$. This is the temperature at which methane begins to be produced along with a variety of $\mathrm{C}_{2+}$ hydrocarbons in sedimentary basins on Earth. At increasing temperatures, methane becomes proportionately more significant, such that by temperatures of about $150^{\circ} \mathrm{C}$, methane is the dominant product of thermogenesis (Tissot and Welte, 1978; Quigley and Mackenzie, 1988; Schoell, 1988; Hunt, 1996; Seewald et al., 1998; Seewald, 2003; Stolper et al., 2015).

Geothermal gradient (the increase of temperature with subsurface depth) is a key parameter for estimating required burial depths for methane-producing thermogenesis. On Earth, typical geothermal gradients in sedimentary basins are about $25-30^{\circ} \mathrm{C} \mathrm{km}^{-1}$, and methane formation by thermogenesis typically begins at depths on the order of $2-2.5 \mathrm{~km}$. Terrestrial gradients are well known from precise downhole temperature data acquired in many petroleum wells, but equivalent data for Mars are not available. Although the evolution of the martian crust-mantle system is complex and still debated (e.g., Grott et al., 2013), martian geothermal gradients in the highlands have been estimated based on gravity and topography data from Mars Global Surveyor (McGovern et al., 2002, 2004). Results suggest that, while many Amazonian features have relatively low gradients $\left(\sim 5-10^{\circ} \mathrm{C} \mathrm{km}{ }^{-1}\right)$, Noachian and Hesperian terrains have higher geothermal gradients $\left(\sim 10\right.$ to $\left.>20^{\circ} \mathrm{C} \mathrm{km}^{-1}\right)$, which approach those in sedimentary basins on Earth. Similarly, comparisons of spectral observations in Nili Fossae with predicted metamorphic mineral assemblages also suggest relatively high Noachian gradients $\left(>20^{\circ} \mathrm{C} \mathrm{km}^{-1}\right)$ and perhaps imply regional hydrothermal activity, possibly associated with impacts (Ehlmann et al., 2009, 2011; McSween et al., 2015).

These results can be used to estimate depths of burial on early Mars that would be required for methane production by thermogenesis of organic matter (of any origin). For example, using a gradient of $20^{\circ} \mathrm{C} \mathrm{km}^{-1}$ and assuming a surface temperature of $0^{\circ} \mathrm{C}$, methane would begin to be produced at a depth of $3 \mathrm{~km}$. Recent work suggests fill thicknesses in the martian lowlands of $\sim 2$ to $4 \mathrm{~km}$ over most of the area and $\sim 5 \mathrm{~km}$ in Utopia (Tewelde and Zuber, 2013), which are well within the range required for thermogenesis. Less burial would be required in areas with higher geothermal gradients due to heterogeneities in crustal thermal properties or heat flow (e.g., in magmatic centers or near very large impacts; Oehler et al., 2005).
For example, it is well recognized that impact-related heating can contribute to hydrocarbon generation on Earth (Parnell et al., 2005). One study of the $5 \mathrm{~km}$ diameter Gardnos impact crater in Norway suggests that even small craters can produce enough heat to melt basement rocks and generate hydrocarbons from target organic matter (Parnell and Lindgren, 2006). Other studies have investigated hydrothermal effects of impacts on Mars, with modeling results suggesting that temperatures generated in and below central peaks and crater rims can be in excess of $100-150^{\circ} \mathrm{C}$, for durations ranging from 67,000 years for a $30 \mathrm{~km}$ diameter crater to 380,000 years for a $180 \mathrm{~km}$ diameter crater (Newsom et al., 2001; Hagerty and Newsom, 2003; Abramov and Kring, 2005; Schwenzer and Kring, 2009a, 2009b; Ivanov and Pierazzo, 2011; Schwenzer et al., 2012). Modeled results also show that the larger the impact, the greater the area of thermal effect, such that for impact craters $>\sim 100 \mathrm{~km}$ in diameter, the regions with subsurface temperatures $>150^{\circ} \mathrm{C}$ can extend beyond the crater rim. Even in impacts where temperatures are so high that most organic matter is destroyed, it has been suggested that some methane could be generated and preserved in fluid inclusions in adjacent rocks (Wycherley et al., 2004). Finally, pyrolysis studies of the abiotic organic matter in the Murchison meteorite show that thermal alteration of the insoluble organic matter produces hydrocarbons including methane (Okumura and Mimura, 2011).

Thus, methane production by thermogenesis of ancient organic material is possible on early Mars, particularly when considering combined effects of burial and enhanced heat flow from magmatism or impacts. Moreover, the estimates of the abundance of abiotic organics delivered to Mars by IDPs, coupled with the pyrolysis studies of Murchison organics, support the concept that abiotic organics could have provided significant starting material for methane-producing thermogenesis. Any methane generated at depth by thermogenesis would have subsequently migrated upward along faults and fractures until it either was trapped and sealed (see Section 5) or reached the surface and escaped to the atmosphere.

3.2.3. Fischer-Tropsch-type (Sabatier) reactions. FischerTropsch-type reactions are a major abiotic process of methane production on Earth, as described and discussed in detail by Etiope and Sherwood Lollar (2013). The reactions refer to hydrogenation of an oxidized form of carbon (typically $\mathrm{CO}$ or $\mathrm{CO}_{2}$ ); this process occurs over a wide range of temperatures $\left(<100^{\circ} \mathrm{C}\right.$ to $\left.\sim 500^{\circ} \mathrm{C}\right)$. On Earth, $\mathrm{CO}$ is not an important natural gas, as it occurs only in trace amounts (ppbv or ppmv levels) in sedimentary or igneous environments. In contrast, $\mathrm{CO}_{2}$ is a major gas in many geologic settings, and it may derive from multiple sources, mainly magma degassing and thermal decomposition of carbonates. So, the $\mathrm{CO}_{2}$-based FTT reaction (the Sabatier reaction) is the pathway that better simulates geologic fluids:

$$
\mathrm{CO}_{2}+4 \mathrm{H}_{2}=\mathrm{CH}_{4}+2 \mathrm{H}_{2} \mathrm{O}
$$

Although the Sabatier synthesis is often considered in aqueous solution (assuming dissolved $\mathrm{CO}_{2}$ and $\mathrm{H}_{2}$ phases to simulate hydrothermal conditions), the reaction (based on heterogeneous catalysis) is effective only in a gas phase 
(e.g., Etiope, 2017), and it should be assumed that abiotic FTT $\mathrm{CH}_{4}$ production occurs in unsaturated rocks and gasfilled fractures.

On Mars, $\mathrm{CO}_{2}$ could derive from magma degassing, thermal decomposition of carbonates at great depths, and the atmosphere (e.g., Oze and Sharma, 2005). Carbonates, in particular, have been detected in association with olivinerich rocks (e.g., at Nili Fossae [Ehlmann et al. 2008; Niles et al., 2013] and Syrtis Major [Michalski and Niles, 2010]). For these reasons, the FTT-Sabatier reaction (or $\mathrm{CO}_{2}$ hydrogenation) is certainly geologically reasonable to have occurred on Mars.

The $\mathrm{H}_{2}$ necessary for FTT-Sabatier reaction can derive from different sources: serpentinization, radiolysis, cataclasis of silicates in fault zones, or magmatic degassing (Smith et al., 2005). Serpentinization, in particular, is widely invoked as a source of $\mathrm{CH}_{4}$ on Mars (e.g., Oze and Sharma, 2005; Atreya et al., 2007). But serpentinization itself does not produce $\mathrm{CH}_{4}$. It is a process that produces $\mathrm{H}_{2}$ and a variety of secondary minerals of the serpentine group $\left([\mathrm{Mg}, \mathrm{Fe}]_{3} \mathrm{Si}_{2} \mathrm{O}_{5}[\mathrm{OH}]_{4}\right)$, as a result of hydration of ferromagnesian minerals (olivine $\left[(\mathrm{Mg}, \mathrm{Fe})_{2} \mathrm{SiO}_{4}\right]$ and pyroxenes $\left.\left[(\mathrm{Mg}, \mathrm{Fe}) \mathrm{SiO}_{3}\right]\right)(\mathrm{Oze}$ and Sharma, 2005; McCollom and Seewald 2007; Schrenk et al., 2013; Holm et al., 2015). The process is common on Earth in ultramafic rocks where it occurs over a wide range of temperatures $\left(<100^{\circ} \mathrm{C}\right.$ to $\sim 400^{\circ} \mathrm{C}$ ) and is a major source of $\mathrm{H}_{2}$ (e.g., Evans, 2004; Oze and Sharma, 2005; McCollom and Seewald, 2007). Serpentinization is important in planetary studies, as the produced $\mathrm{H}_{2}$ may serve as feedstock for the FTT reactions that could produce abiotic methane as well as an energy source for potential chemotrophic organisms (including methanogens; Schulte et al., 2006). The existence of serpentinization on Mars is discussed in Section 4.2.1.

In addition to molecular $\mathrm{H}_{2}$ and $\mathrm{CO}_{2}$, the Sabatier reaction requires a metal catalyst, such as iron, nickel, chromium, and ruthenium. The occurrence of such catalysts in rocks, especially ruthenium that can support the reaction at very low temperatures $\left(<100^{\circ} \mathrm{C}\right.$; Etiope and Ionescu, 2015), is a key factor for the production of abiotic $\mathrm{CH}_{4}$. Consequently, while radiolysis in basalts may be an important source of $\mathrm{H}_{2}$ on Earth and Mars, the paucity of metal catalysts in basalts (compared to ultramafic rocks) makes methane production from the FTT-Sabatier reaction less effective and probable in basalts. This may explain why on Earth abiotic methane is typically associated with ultramafic rocks, and not basalts. The existence of potential Sabatier catalysts on Mars is discussed in Section 4.2.2.

3.2.4. UV irradiation or ablation-pyrolysis of meteoritic organics. Methane can be produced by UV irradiation of organics. This process has been shown to occur in organic matter in carbonaceous chondrites and IDPs exposed to UV radiation, under simulated martian conditions (Keppler et al., 2012; Moores and Schuerger, 2012; Schuerger et al., 2012). Results could support various levels of atmospheric methane (from $\sim 2-5$ ppbv and even $8-10$ ppbv) depending on the meteorite/IDP flux, the weight percent methane in the incoming materials, the organic carbon to methane conversion rate, and the lifetime of methane on the martian surface.

It is additionally conceivable that some methane formed by UV irradiation on meteorites could be implanted in the regolith, though it is unlikely that this process could account for more than trivial amounts of subsurface methane. In addition, although the depth of UV penetration into martian materials is not well understood (Carrier et al., 2015), it is likely to be shallow (on the order of a few hundred microns; Muñoz Caro et al., 2006). Therefore, this process may contribute to some variation in background levels of atmospheric methane (Webster et al., 2016), but it is not likely to be a significant source for methane in the martian subsurface.

3.2.5. High-temperature geothermal reactions. Methane can be produced by a series of abiotic (non-FTT) mechanisms at temperatures above $150^{\circ} \mathrm{C}$ (Etiope and Sherwood Lollar, 2013). These mechanisms include hydrolysis or hydrogenation of metal carbides; $\mathrm{CO}, \mathrm{CO}_{2}$, or carbonate reduction with $\mathrm{H}_{2} \mathrm{O}\left(>500^{\circ} \mathrm{C}\right)$; respeciation of $\mathrm{C}-\mathrm{O}-\mathrm{H}$ fluids during magma cooling $\left(<600^{\circ} \mathrm{C}\right)$; carbonate-graphite metamorphism and reduction of graphite with $\mathrm{H}_{2} \mathrm{O}\left(<400^{\circ} \mathrm{C}\right)$; iron carbonate decomposition and siderite decomposition with $\mathrm{H}_{2} \mathrm{O}\left(300^{\circ} \mathrm{C}\right)$; thermal decomposition of carbonates $\left(250-870^{\circ} \mathrm{C}\right)$; and uncatalyzed aqueous $\mathrm{CO}_{2}$ reduction $\left(>150^{\circ} \mathrm{C}\right)$ (Etiope and Sherwood Lollar, 2013, and references therein). Knowing which processes actually occur in terrestrial geothermal systems often remains elusive. In addition, geothermal fluids on Earth often interact with organic-rich sedimentary rocks such that it is not easy to distinguish methane of abiotic origin from that produced by thermal degradation of biotic organic matter (Fiebig et al., 2007). However, geothermal fluids are dominated by $\mathrm{CO}_{2}$ (and water vapor), and methane is typically a minor component.

3.2.6. Magma (volcanic) degassing. As on Earth, primordial methane could exist in deep martian rocks, magma, and the mantle, as a gas formed during Mars' accretion. Methane in magmatic fluids can also form from $\mathrm{CO}, \mathrm{CO}_{2}$, or carbonate reduction at pressures between 5 and $11 \mathrm{GPa}$ and temperatures ranging from $500^{\circ} \mathrm{C}$ to $1500^{\circ} \mathrm{C}$ (Scott et al., 2004). This type of magmatic methane could be associated with ancient volcanic systems on Mars; and as Mars is likely, still, to be internally active with a potential for deep magmatic and hydrothermal activity (Dohm et al., 2008), temperatures on the order of $700-1000^{\circ} \mathrm{C}$ may occur at depths of $50 \mathrm{~km}$ (Oze and Sharma, 2005). However, it is important to note that, at least on Earth, magma does not contain significant amounts of methane (concentrations are generally on the order of a few ppbv), and volcanoes are not important methane emitters (Welhan, 1988; Capaccioni et al., 2004; Etiope et al., 2007; Fiebig et al., 2007).

\section{Potential Sites and Timing of Methane Generation on Mars}

\subsection{Sedimentary basins}

On Earth, organic-rich shales, concentrated in distal facies of sedimentary basins, are the major repositories for organic matter. It is in these facies that thermogenesis during burial commonly produces methane from alteration of biogenic kerogen preserved in the shales. On Mars, organic matter in fine-grained sediments could be abiotic (delivered to the planet by meteorites and IDPs; Flynn, 1996; Benner 
et al., 2000; Llorca, 2004) or biotic (derived from potential early life-forms transported into the basins and/or formed in place; Oehler and Allen, 2012a). Such accumulations of organic matter could provide fuel for potential methanogenic microbes and additionally could be converted to hydrocarbons including methane by thermogenesis (as described in Section 3.2.2).

Figure 2A illustrates key regional features on Mars, including the large quasi-circular depressions (QCDs) in the northern plains, interpreted to be basins formed by major impacts that occurred during the early Noachian, between $\sim 4.2$ and $4 \mathrm{Ga}$ (Frey et al., 2002; Frey, 2004, 2008). These impact basins could house significant thicknesses of sedimentary units that were deposited in lakes, ponded water, or ocean basins during the wetter periods on Mars. For example, Acidalia is not only likely to have received sediments from runoff through the valley networks on early Mars, but it also would have been the focal point for deposition of fine-grained sediments carried into the Chryse-Acidalia embayment by the massive, late Hesperian Circum-Chryse outflows (Carr, 1979; Komar, 1979, 1980; Rice and Edgett,1997; Kreslavsky and Head, 2002; Tanaka et al., 2005; Salvatore and Christensen, 2014a, 2014b) and possibly by contributions from the late Noachian to Hesperian Uzboi-Ladon-Morava (ULM) outflows (Irwin and Grant, 2013). Streamlined islands in northern Chryse and southern Acidalia, as well as the continuous deepening of topography at the intersection of the two basins, argue for significant spillover from Chryse into Acidalia during the flooding events. Together, these data suggest that ancient distal-facies sediments are likely to be concentrated in Acidalia. A distal-facies scenario can be supported, additionally, by the occurrence of mud-volcano-like mounds and giant polygons, both of which have analogies to terrestrial features that occur exclusively in thick accumulations of fine-grained sediments (Oehler and Allen, 2010, 2012b; Etiope et al., 2011b).

Utopia is similar in that it is a huge, Noachian lowland basin that would have received runoff from the valley networks on early Mars as well as infill from outflows that traverse well into the basin. The Utopia outflows are thought to have been early Amazonian and appear to consist of both lava and debris/mud flows that originate from the southwestern flank of Elysium Mons (Thomson and Head, 2001; Russell and Head, 2003). Fine-grained, distal facies of the debris flows could have accumulated in the deeper parts of the basin and may have concentrated organics that were present in the catchment area. Like Acidalia, Utopia is characterized by mud-volcano-like mounds and giant polygons (Skinner and Tanaka, 2007; McGowan and McGill, 2010; Ivanov et al., 2014).

Both basins have some of the lowest elevations in the northern plains and show a profusion of craters with doublelayer ejecta morphologies; these ejecta morphologies have been interpreted as reflecting ancient topographic lows that may have served as depo-centers for sediments and fluids from outflow floods or past lakes/oceans (Barlow and Perez, 2003). The proximity of Utopia to Elysium Mons and of Acidalia to faults radiating from Alba Patera in the Tharsis region (Fig. 2B) provides the possibility of magmatic heating in addition to heating due to burial and impact in these two basins, and this heating could have enhanced thermal alteration of accumulated organics.

Other areas for potential methane generation could include portions of the proposed giant basin in Arabia Terra
(Dohm et al., 2007), the ULM system of paleo-lakes (Irwin and Grant, 2013), valleys in the Valles Marineris system, the giant Hellas and Argyre impact basins, and Isidis and Chryse Planitiae in the northern plains (Fig. 2A). Each of these areas has the potential to have been a site of concentration and preservation of organic materials that could subsequently have been thermally cracked to methane, given sufficient heating from impacts, burial, or magmatic input from the major volcanic constructs (Tharsis, Elysium Mons, and Syrtis Major; Fig. 2B). Given that heat flows for the Noachian are expected to be 2-4 times higher than that of present-day Mars (Clifford et al., 2010), coupled with the fact that large impacts were most common early in martian history, subsurface conditions for thermogenesis may have been most favorable on Mars in the early part of its history.

\subsection{Mafic/Ultramafic rocks}

Intrusive mafic and ultramafic rocks are sites where methane produced by FTT-Sabatier reactions could occur. As discussed in Section 3.2.3, the FTT-Sabatier reaction requires $\mathrm{H}_{2}, \mathrm{CO}_{2}$, and metal catalysts. Serpentinization is just one method of producing $\mathrm{H}_{2}$, but for Mars it is particularly important because (a) it has been actually detected by CRISM (Ehlmann et al., 2010), and (b) it can occur in ultramafic rocks that host the necessary catalysts for the FTTSabatier reaction.

4.2.1. Serpentinization sites. We know that serpentinization has occurred on Mars from orbital detections of serpentine by the Compact Reconnaissance Imaging Spectrometer for Mars (CRISM) (Ehlmann et al., 2010). In addition, recent work based on martian crustal petrology suggests that serpentinization may have been a major process in the martian subsurface that could have produced 2 orders of magnitude more $\mathrm{H}_{2}$ than radiolysis (Mustard and Tarnas, 2017).

Olivine and pyroxene required for serpentinization are common minerals on Mars, as shown by a variety of orbital and rover-based studies as well as analyses of martian meteorites (Christensen et al., 2003, 2005; Hoefen et al., 2003; Bibring et al., 2005; Mustard et al., 2005; Rogers et al., 2005; Poulet et al., 2007; Koeppen and Hamilton, 2008; Salvatore et al., 2010; Ody et al., 2012, 2013; Bish et al., 2013; Mustard and Tarnas, 2017). For example, olivine is a component of most nakhlites and comprises $\sim 60 \%$ of some shergottites and $85-90 \%$ of chassignites (Treiman et al., 2007; Koeppen and Hamilton, 2008). Data from the Observatoire pour la Minéralogie, l'Eau, les Glaces, et l'Activité (OMEGA) on ESA's Mars Express Orbiter and the Thermal Emission Spectrometer (TES) on NASA's Mars Global Surveyor show significant distributions of olivine in the southern highlands and specific concentrations at Nili Fossae, Terra Tyrrhena, north Argyre, and eastern Valles Marineris (Fig. 2A); pyroxene has similar global distributions, as summarized by Koeppen and Hamilton (2008). Finally, large blocks of the ultramafic rock, dunite (typically having $>90 \%$ olivine), have been identified by orbital spectroscopy in mega-breccia in central peaks (Mustard and Tarnas, 2017).

Until recently, there were few confident CRISM detections of mafic minerals in bedrock of the lowlands. However, 
several studies have since detected olivine and pyroxene in crater walls, rims, and ejecta within the lowlands. Salvatore et al. (2010) reported olivine and clinopyroxene in 182 craters in Acidalia and Chryse Planitiae and concluded that in southern Acidalia and Chryse Planitiae basaltic bedrock exposure occurs just meters below the surface. Similar results were obtained from Utopia impact craters by Ody et al. (2014), using OMEGA and CRISM data. These authors further noted that the entire northern plains may have been blanketed by thick, olivine-rich basalt, supporting the earlier suggestion of Head et al. (2002) that the northern plains were filled by $\sim$ a kilometer-thick layer of lavas during the early Hesperian. And Pan et al. (2016) reported CRISM analyses of 431 lowland craters, suggesting that olivine and pyroxene are present in the subsurface of the lowlands from the near surface to depths of several kilometers.
While the combination of all these data suggests that basalts, and possibly ultramafics, are common in the crust of Mars, actual detections of serpentine are relatively few. Recent serpentine detections by CRISM include several Noachian examples (Nili Fossae, west of Isidis, the Claritas Rise, and a few craters in Arabia Terra; Ehlmann et al., 2010). The detections at Nili Fossae occur along with olivine and carbonate in a heavily fractured unit; this would be consistent with serpentinization, as these minerals represent both the reactants and products of the process, and the fractured fabric of that unit (and a possibly similar example shown in Fig. 4A) could be explained by the $30-50 \%$ volume-expansion that occurs when olivine is converted to serpentine (Ehlmann et al., 2010). These observations support the conclusion that the process of serpentinization has occurred on Mars in the past. However, regarding the paucity of
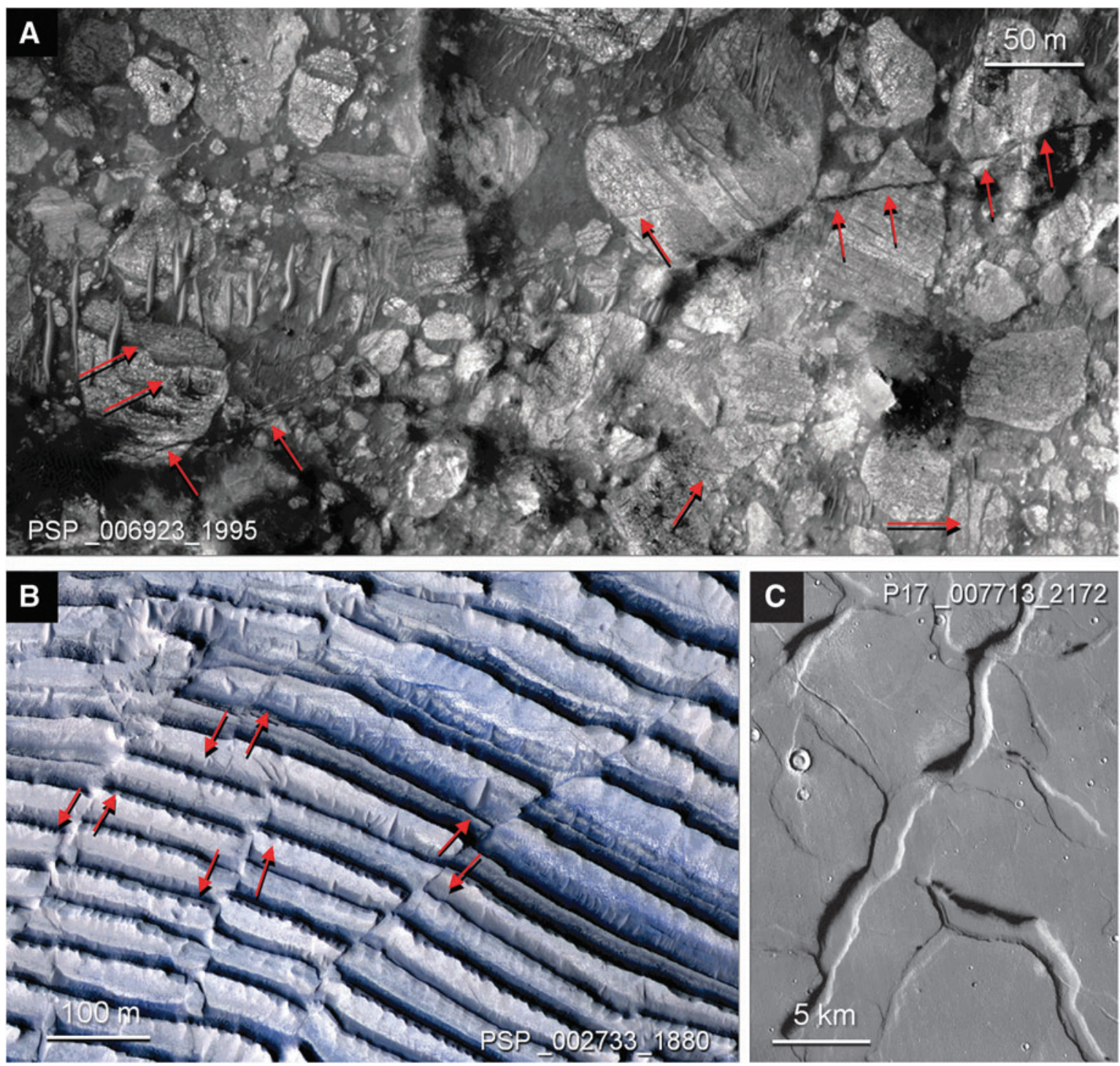

FIG. 4. Examples of faults and fractures on Mars that could enhance seepage from deep, major faults (e.g., Fig. 2B) or those associated with large impacts (e.g., Fig. 6). (A) High Resolution Imaging Science Experiment (HiRISE) image illustrating multiple fractures and faults in megabreccia in Nili Fossae. Arrows point to examples. (B) HiRISE image of faults in dunes in Danielson Crater, Arabia Terra. Arrows indicate relative displacements. (C) Context Camera (CTX) image

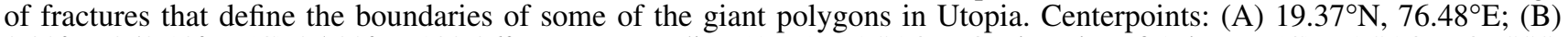
$8.09^{\circ} \mathrm{N}, 353.18^{\circ} \mathrm{E}$; (C) $35.89^{\circ} \mathrm{N}, 103.86^{\circ} \mathrm{E}$. Image credits: (A-B) NASA/JPL/University of Arizona; (C) NASA/JPL/MSSS. 
serpentine detections, it is important to remember that CRISM only detects minerals at the martian surface, in areas with little dust, and that any present-day serpentinization (which could only occur at depth where liquid water is stable) would not be detectable by CRISM, nor would serpentine that formed in the past that is either dust-covered or buried by younger sediments. Therefore, even though only few clear serpentine detections are known, it is certainly possible that serpentinization has been (and still could be) a major process on Mars.

Primary filters for prediction of sites where serpentinization could occur on Mars would be the presence of olivine, pyroxene, and liquid water. As noted above, olivine and pyroxene are clearly abundant in the highlands, and relatively recent data suggest that the lowlands, too, contain significant buried basalt that is rich in these key minerals (Salvatore et al., 2010; Ody et al., 2014; Pan et al., 2016). These results are consistent with the work of Frey (2006a, 2006b), suggesting that the deep, buried crust of the lowlands is ancient (no younger than early Noachian), and with comments by Schulte et al. (2006) that the crust of Mars may be more ultramafic than previously appreciated. It may be, therefore, that the older, buried crust in the lowlands resembles the Noachian crust of the highlands in mineral content. If so, this would provide Mars with a global presence of olivine and pyroxene that could be subject to serpentinization, when exposed to liquid water for relatively long periods of time.

Areas (see Fig. 2A-2B) with potential for significant input of liquid water would include the deep basins of the lowlands, where runoff, outflow activity, and potential ocean waters would have been concentrated. Other sites may exist along the martian dichotomy (where deep faulting may have opened conduits for long-lived upwelling fluids; see Section 6); some of the chasmata of Valles Marineris (again because of expected deep faulting); the $1200 \mathrm{~km}$ diameter, Noachian Argyre impact basin in the highlands (where deep impactgenerated faults have been proposed as conduits for longlived fluid migration; Soare et al., 2014); and other sites of deep fracturing (e.g., those associated with the buildup of Tharsis). Additional areas might include the ULM system of lakes and the proposed ancient basin in Arabia Terra. Finally, proximity to the large shield volcanoes (Tharsis, Syrtis Major, and Elysium Mons) might enhance the long-term presence of liquid water in the subsurface.

The need for liquid water might argue that the process of serpentinization may have been most common on the planet in its early history, and in the subsurface, when combined effects of relatively high concentrations of radiogenic materials, heating from magmatic centers, and permeation of surface runoff could have resulted in an abundance of liquids at depth.

4.2.2. FTT-Sabatier reaction sites. Ultramafics are the best rocks for FTT-Sabatier reactions. These reactions require, in addition to $\mathrm{H}_{2}$ and $\mathrm{CO}_{2}$ or $\mathrm{CO}$, a metal catalyst such as $\mathrm{Fe}, \mathrm{Ni}, \mathrm{Cr}$, and $\mathrm{Ru}$. In this respect, it is useful to note that, on Earth, a peculiar relationship exists between abiotic $\mathrm{CH}_{4}$ and chromitites occurring in ophiolites or peridotite massifs in association with serpentinized rocks (Etiope and Ionescu, 2015). Chromitite (an igneous cumulate rock composed mainly of the mineral chromite $\left[\mathrm{FeCr}_{2} \mathrm{O}_{4}\right]$ ) can contain significant amounts of FTT catalysts and especially ruthenium.
Ruthenium is a powerful catalyst that is known to be capable of supporting the Sabatier reaction at very low temperatures (even $20-25^{\circ} \mathrm{C}$ ) without the need for hot hydrothermal environments. Chromite with ruthenium actually exists on Mars; it has been detected in the martian meteorites, Chassigny and the Chassignite NWA 2737, where ruthenium concentrations extend up to $160 \mathrm{ppb}$ (Jones et al., 2003; Baumgartner et al., 2016). Mars Global Surveyor TES data were used to map possible source locations for Chassigny (actually, sites with olivine spectral components like those of Chassigny; Hamilton et al., 2003; Koeppen and Hamilton, 2008); the main sites identified were in faulted terrains in Nili Fossae, eastern Valles Marineris, and northern Argyre (Fig. 5).

The metal catalysts $\mathrm{Ni}, \mathrm{Fe}$, and $\mathrm{Cr}$, which are particularly abundant in chromitites and other intrusive igneous rocks, could also support the Sabatier reaction, but they need higher temperatures, generally above $200^{\circ} \mathrm{C}$ (Wang et al., 2011; Etiope and Ionescu, 2015). It is likely then that these elements could be important for FTT reactions on Mars in very deep rocks or in regions of high heat flow.

\subsection{Geothermal and magmatic systems}

Hot fluids and magmatic systems existed on Mars in the past in several volcanic provinces, mainly Tharsis, Elysium Mons, and Syrtis Major (Fig. 2A). Tharsis is the largest volcanic area on Mars, more than 20 million $\mathrm{km}^{2}$ in areal extent and including five large volcanoes (Olympus Mons, Alba Patera, and the three volcanoes of Tharsis Montes). While most of the activity in these martian volcanoes occurred in the past, these areas, by analogy with extinct volcanoes on Earth, could still host active geothermal-magmatic fluid circulation at depths of a few kilometers (Dohm et al., 2008). Accordingly, they could represent potential sources of past or present methane. While we note again that magmatic systems (if they do not interact with organic-rich sediments) bear only trivial amounts of methane on Earth, even part-perbillion-by-volume concentrations of methane on Mars could represent a significant contribution to the low $\mathrm{CH}_{4}$ levels of the martian atmosphere.

\section{Potential Sites of Methane Accumulation on Mars}

After methane is generated, it will migrate in the subsurface along permeable layers/fractures until it is either trapped (in porous reservoirs, clathrates, or zeolites) or expelled by seepage at the surface. In some cases, hydrocarbons seep directly from source rocks (e.g., Etiope et al., 2013a) that may be fractured and/or have high pore-fluid pressures due to hydrocarbon generation (Passey et al., 2010; Feinstein et al., 2015).

\subsection{Traps and seals}

Traps with effective seals (cap rocks) are a prerequisite for conventional gas accumulations. Because plate tectonics has been minimal to nonexistent on Mars (Section 6), it might be thought that structural traps would be less abundant on Mars than on Earth. However, impact processes result in faulted terrains (Fig. 6) (Melosh, 1989; Osinski and Spray, 2005), particularly in complex craters (which on Mars are generally $>7 \mathrm{~km}$ in diameter), and these faulted terrains create a variety of traps that could host methane 

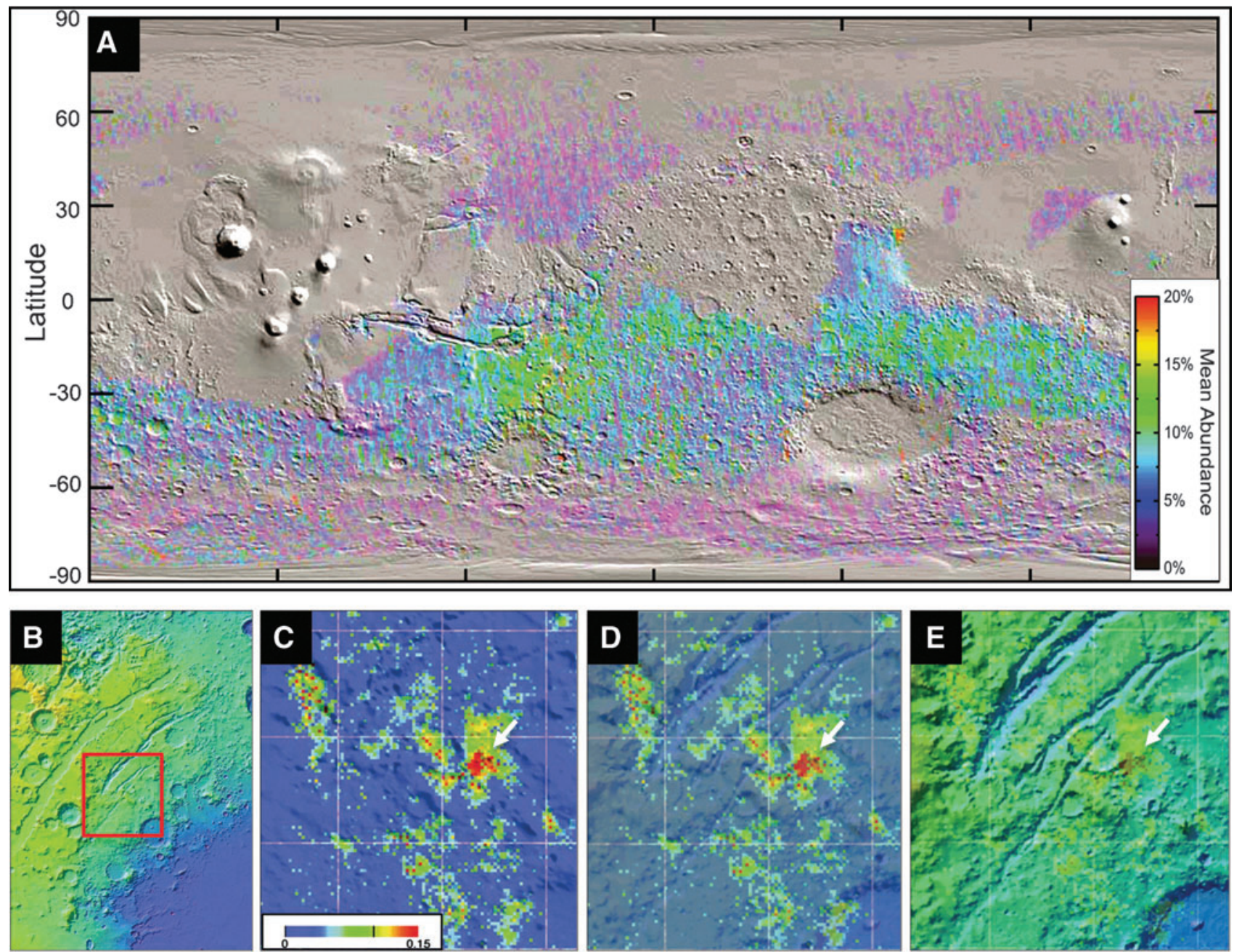

FIG. 5. Olivine and Chassigny-like end-member $\left(\mathrm{Fo}_{68}\right)$ distributions. Data from the Mars Global Surveyor TES indicating olivine distribution (A) and details in Nili Fossae area of Chassigny martian meteorite-like olivine with molar ratio of $\mathrm{Mg}$ / $\mathrm{Mg}+\mathrm{Fe}$ of 0.68 (designated as $\mathrm{Fo}_{68}$ ). (A) Total mean surface-normalized abundance of olivine overlaid on MOLA global shaded relief map. (B) MOLA map of Nili Fossae area (yellows are highs, and blues are lows); rectangle is area shown in (C-E). (C-E) $\mathrm{Fo}_{68}$ (Chassigny-like end-member) distribution, overlaid on MOLA topography. (C) Overlay is with $20 \%$ transparency (scale shows concentration of $\mathrm{Fo}_{68}$, and vertical line in scale denotes the detection limits, with data interpolated to fill the map). (D) Overlay is with $60 \%$ transparency. (E) Overlay is with $80 \%$ transparency. Arrows in (C-E) point to the same location (with highest $\mathrm{Fo}_{68}$ abundance). (A) Adapted from Koeppen and Hamilton (2008); (C-E) adapted from Hamilton et al. (2003).

accumulations. For example, on Earth, dozens of impact structures in North America produce commercial quantities of hydrocarbons that are trapped in impact-related central uplifts, crater rims, slump terraces, and likely subcrater fracture zones (Donofrio, 1998; Barton et al., 2010). In addition, data from Haughton Crater, a $23 \mathrm{~km}$ diameter crater in the Canadian Arctic (studied intensely in outcrop and through seismic data; Osinski and Spray, 2005), illustrate the complexity of structures formed by the impact process (uplifted fault blocks; concentric, radial, and detachment faults; collapse graben; rollover anticlines), many of which could produce traps for migrating gas. So even with limited to no plate tectonics, it is likely that the martian subsurface could contain an extensive network of impact-induced traps. Impacts on Mars are abundant in both the southern highlands and the northern lowlands, even though many of the oldest craters in the lowlands have been buried by subsequent sedimentation and are detected only as "ghost" or "stealth" craters (where only hints of their rims are apparent in visible data) or QCDs (that are only detectable in MOLA data) (Frey, 2004, 2006a, 2006b).

If effective seals are present, then it is possible that methane accumulations in these types of traps could persist in the subsurface for extended periods. Effective seals for methane are typically thick, laterally continuous, ductile rocks with high capillary entry pressures; among the best are salt, anhydrite, and continuous permafrost (Portnov et al., 2013; Wang et al., 2014). It has been suggested that, on Mars, the cryosphere is kilometers thick (Clifford et al., 2010), and extensive ground ice (perhaps the remnant of an ancient ocean) exists in the lowlands (Mouginot et al., 2012; Clifford et al., 2013; Petitjean et al., 2014; Stuurman et al., 2016). This ice could form effective permafrost seals, 


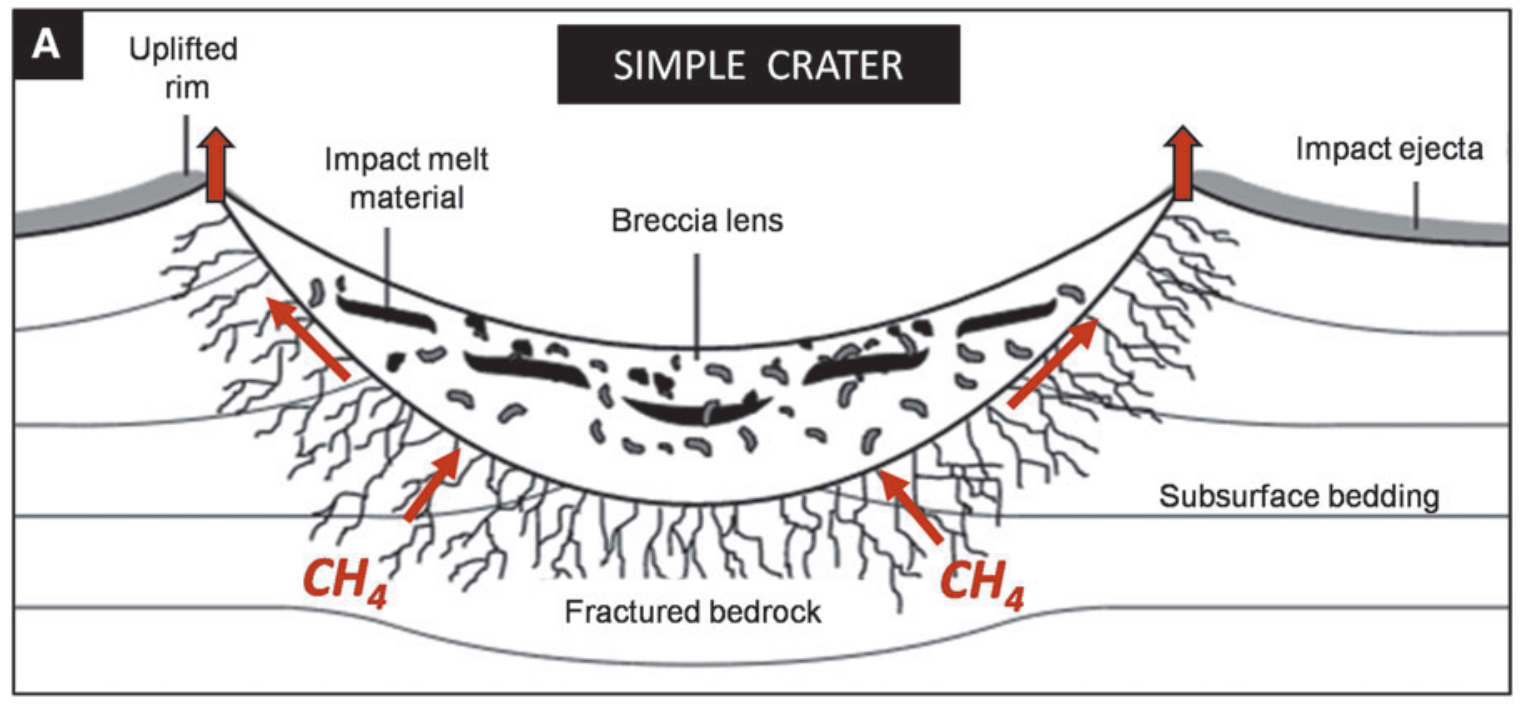

B

COMPLEX CRATER

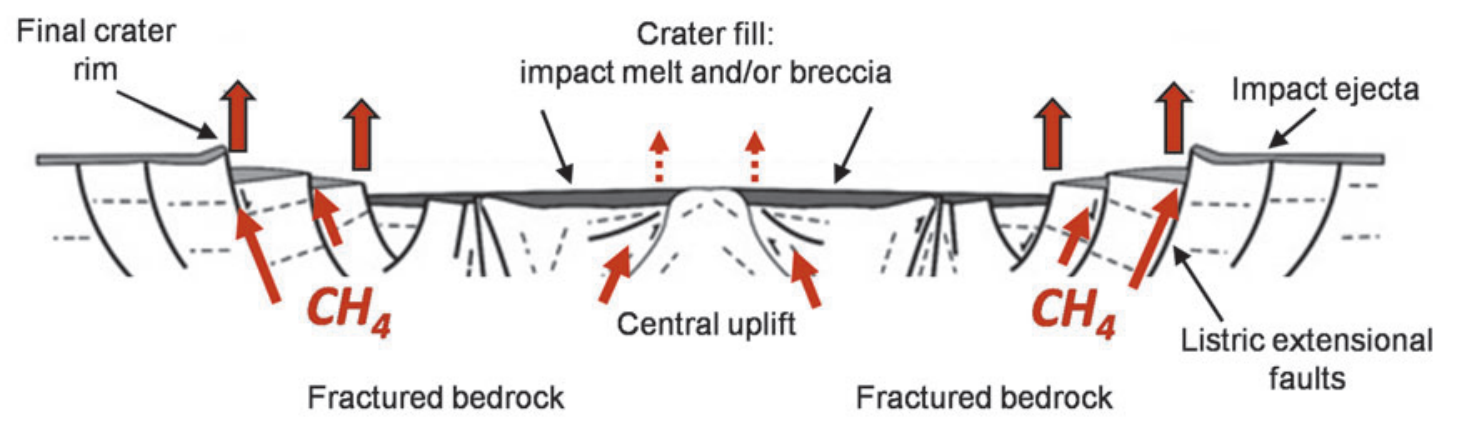

FIG. 6. Schematic cross sections of impact craters. These illustrate potential $\mathrm{CH}_{4}$ generated at depth (by any process) and subsequent fluid flow (arrows) through fractures, faults, and unconformity surfaces. (A) Simple crater, adapted from French (1998). (B) Complex crater, adapted from Melosh (1989) and Osinski et al. (2005); dashed arrow indicates potential $\mathrm{CH}_{4}$ release associated with central uplifts.

enhancing the possibility that trapped subsurface methane could exist in the martian lowlands.

\subsection{Reservoirs (porous rocks, clathrates, zeolites)}

On Mars, reservoir-quality rocks within sealed traps could act as methane reservoirs, as could clathrates and zeolites (Downey, 1984; Chastain and Chevrier, 2007; Max et al., 2011, 2013; Lasue et al., 2015; Mousis et al., 2016). Reservoirs can be either porous and permeable sedimentary rocks (like sandstone) or fractured rocks with lower intrinsic porosity (like some carbonates, basalts, and ultramafics), where the fracturing produces secondary porosity and permeability, creating storage space for gas or liquids. Discussions of martian rock fracturing, porosity, and permeability are included in the works of MacKinnon and Tanaka (1989) and Hanna and Phillips (2005) and references therein (also see discussion in Section 6). In addition, olivine hydration generates large volume changes and high local strains and stresses with resultant cracking (Macdonald and Fyfe, 1985; Etiope et al., 2013b), so it is possible that, on Mars, fracturing during serpentinization may form important reservoir rocks.
Clathrates are crystalline, ice-like structures that hold methane within the cagelike lattice of frozen water molecules. On Earth, they typically form in cold, deep ocean settings, within the hydrate stability zone, which commonly extends downward from the sediment-water interface into the subsurface. Below the hydrate stability zone, methane will exist as a gas. Methane clathrates require either liquid water or ice to form, and they are common in permafrost and subsurface sediments along continental margins. They tend to form in coarse-grained sediments with high permeability, where migrating gas and ice can accumulate. On Mars, methane clathrates are estimated to occur over a great range of depths (10 m to $20 \mathrm{~km}$; Max et al., 2013) and may provide a storage capacity of $\sim 3.3 \times 10^{14}$ to $3.5 \times 10^{17}$ tonnes of $\mathrm{CH}_{4}$ (Lasue et al., 2015), an amount that could account for sporadic, episodic releases such as the $\sim 19,000$ tonnes implied by Mumma et al. (2009).

Zeolites, which form by reaction of alkaline waters with volcanic rocks and ash, have been detected in numerous settings on Mars (Ruff, 2004; Ehlmann et al., 2009; Carter et al., 2013), and they are expected to be widespread in the martian regolith (Mousis et al., 2016). Carter et al. (2013) 
concluded that most zeolites formed during the Noachian, though they also reported some in the younger lowlands (possibly related to ice-volcano interactions). The mechanism of trapping and storage of methane is proposed to be adsorption into the ring structure of the zeolites, with chabazite and clinoptilolite having ring structures sufficiently large to accommodate methane molecules. Zeolites would be expected to be most abundant in settings where liquid water has been long-lived and in contact with volcanoes.

The Acidalia and Utopia basins stand out as excellent candidates for hosting sealed traps where methane may have accumulated in the subsurface. These lowland basins were depo-centers for "immense" volumes of water in the past (Thomson and Head, 2001; Salvatore and Christensen, 2014a, 2014b), and because of their northern latitudes, they have the potential to contain thick and continuous permafrost that could host clathrates and zeolites, and seal trapped methane. Such methane could ultimately be abiotic and/or biotic, and it could be recent or ancient.

\section{Seepage Pathways on Mars}

On Earth, faults and fractured rocks represent preferential pathways for seeping gas, and it is expected the same would occur on Mars. However, many faults and fractures on Earth are associated with plate tectonics. On Mars, plate tectonics is generally thought to have been absent for most of the planet's history. There is some evidence for very early ( $>4 \mathrm{Ga}$ ) plate tectonic activity on the planet (Sleep, 1994; Connerney et al., 1999; Dohm et al., 2015), and one study has suggested possible recent, though minor, plate tectonic activity in Valles Marineris (Yin, 2012). Nevertheless, Mars has had its own history of tectonism and faulting that resulted from stresses related to the formation and evolution of the dichotomy, the Noachian-Hesperian buildup of Tharsis, planetary cooling, Amazonian volcanism, and continuing impacts (Golombek and Phillips, 2009; Grott et al., 2013). Moreover, any of the major faults and fracture systems that developed early in the planet's history may have been reactivated by subsequent stresses, as is common on Earth. So, while the tectonic history of Mars has been very different from that of Earth, there is a profusion of faults and fracture networks on Mars that could serve as conduits for gas migration in the subsurface (Fig. 2B).

For example, Tharsis (Fig. 2A-2B) is an enormous, elevated volcanic edifice that covers about a third of the planet and is surrounded by an extensive system of radial extensional features (rifts and graben; Knapmeyer et al., 2006; Hauber et al., 2010) and generally concentric compressional features that form wrinkle ridges (thought to overlie thrust faults) that continue over the entire western hemisphere (Banerdt et al., 1992) and large portions of the northern lowlands (Withers and Neumann, 2001; Head et al., 2002). These could provide routes for fluid migration from great depth.

The dichotomy on Mars also could provide routes for seeping methane. The dichotomy marks the boundary between the northern lowlands and southern highlands, with major differences in elevation $(\sim 5 \mathrm{~km})$ and crustal thickness ( $\sim 32 \mathrm{~km}$ in the north versus $\sim 58 \mathrm{~km}$ in the south) (Golombek and Phillips, 2009). One explanation for the dichotomy is that it represents the rim of a huge, oblique impact that formed the lowlands in one of the earliest recorded geologic events on the planet (Wilhems and Squyres, 1984; AndrewsHanna et al., 2008; Marinova et al., 2008; Golombek and Phillips, 2009). Ongoing activity along the dichotomy is suggested by erosion along that boundary and possible late Noachian/early Hesperian deformation, perhaps due to faulting in response to flexural stresses caused by differences in crustal thickness as well as bending, erosion, and global contraction (Watters, 2003a, 2003b) or relaxation of the boundary by lower crustal flow (Guest and Smrekar, 2005). Mapped extensional faults also can be seen to be concentrated along portions of the dichotomy (Fig. 2B), particularly in the regions west of Isidis and east of Gale Crater. These faults could extend exceedingly deep into the subsurface and may have been reactivated throughout martian history by continuing planetary stresses, providing long-term conduits for seeping fluids.

In addition, impact craters on Mars most likely provide an extensively fractured subsurface (e.g., Fig. 6). Impact fracturing has been studied by experimental and simulation models coupled with field observations, drilling results, and seismic studies of terrestrial impact craters (Melosh, 1989; Osinski and Spray, 2005; Osinski et al., 2005; Kumar and Kring, 2008; Salguero-Hernández et al., 2010). Results suggest that such fracturing extends deep into the subsurface. For example, the $\sim 1.2 \mathrm{~km}$ diameter Meteor Crater shows fracturing to depths of $\sim 1 \mathrm{~km}$, and the $22 \mathrm{~km}$ diameter Ries Crater shows fractured basement to $\sim 6 \mathrm{~km}$ depth (Ahrens et al., 2002). Because of the density of impact craters on Mars, including the buried and ghost craters in the northern lowlands (e.g., Frey et al., 2002; Frey, 2004, 2008), it is likely that the subsurface of Mars is heavily fractured. A similar conclusion was reached by Rodríguez et al. (2005).

Additional faulting (Fig. 4) on Mars may be related to local tectonism, from basin subsidence or uplift (due to sediment deposition and erosion/ice sublimation, respectively), as well as from lateral compressional or extensional stresses. Giant polygons (Fig. 4C) may also provide pathways for seeping fluids. These features are exclusive to the martian lowlands and are particularly abundant in Acidalia and Utopia. The origin of these fractures is still debated, but one terrestrial analogy suggests that they may form in areas of subaqueous fine-grained sediment accumulation and could function as both sources and conduits for seeping fluids, including methane (Oehler and Allen, 2012b). By analogy to the terrestrial polygons, the fractures of the giant polygons in Acidalia and Utopia could penetrate to depths of $\sim 700 \mathrm{~m}$. Though not as deep as faults and fractures associated with Tharsis, the dichotomy, or large impacts, the fractures associated with the giant polygons on Mars could link with deeper fractures, providing near-surface enhancement of potential methane seepage.

In summary, the martian subsurface is likely to be highly fractured. Faults from an early phase of plate tectonics, the buildup of Tharsis, the dichotomy-forming event, and major impacts would penetrate deep into the subsurface and could potentially tap liquid water and provide conduits for seeping methane. Other faults, associated with smaller impacts, local tectonics, and possibly the giant polygons, would provide a shallower network that could link some of the deeper faults to the surface. This scenario provides multiple pathways for methane seepage, and methane generated at depth could migrate through these fracture networks as well as updip 
along tilted permeable beds and along unconformity surfaces below crater fill (e.g., Fig. 6).

\section{Potential Sites of Methane Seepage on Mars}

On Mars, we have observed diverse features that resemble some of the terrestrial expressions of macro-seeps, including mud-volcano-like mounds, possible ancient spring deposits, and flow structures along crater rims. Other sites are highlighted as potential locations for microseepage (the diffuse exhalations). Clearly, evaluation of candidate methane release sites requires assessment of potential locations of subsurface methane generation and accumulation as well as the presence of faults/fractures that could facilitate seepage. Examples are discussed below.

\subsection{Potential sites of macro-seepage}

Most of the known martian features that could represent gas macro-seeps are ancient. While they may have been sites of methane emission in the past, they may remain as sites for some degree of continuing seepage today. Below, we discuss potential martian sites of macro-seepage in mud-volcano-like mounds in Acidalia, Utopia, and other areas, possible ancient spring deposits, large crater rims, and geothermal-volcanic areas.

7.1.1. Mud-volcano-like structures-Acidalia, Utopia and other areas. Mud volcanoes are major methane macroseeps on Earth. Mud-volcano-like mounds are especially abundant in Acidalia (Fig. 7A-7G) and Utopia and have been reported from numerous other areas, including Isidis, Scandia, Chryse Planitia, Candor Colles, Candor Chaos, Coprates Chasma, and craters in Arabia Terra (e.g., Davis and Tanaka, 1995; Tanaka, 1997, 2005; Tanaka et al., 2000, 2003, 2008; Farrand et al., 2005; Kite et al., 2007; Rodríguez et al., 2007; Skinner and Tanaka, 2007; Allen et al., 2009, 2013; McGowan, 2009; Oehler and Allen, 2009, 2010, 2011; Skinner and Mazzini, 2009; Chan et al., 2010; Komatsu, 2010; McGowan and McGill, 2010; Pondrelli et al., 2011; Franchi et al., 2014; Ivanov et al., 2014; Okubo, 2014, 2016; Komatsu et al., 2016a, 2016b).

These martian mounds resemble terrestrial mud volcanoes (Fig. 7H-7J) in many respects: size, circular to subcircular shapes, morphology including pitted cones or domes with flat to depressed crests, concentric crestal rings (similar to remnants of mud lakes in terrestrial mud volcanoes), moats suggestive of subsurface sediment removal, apronlike extensions onto the plains, associated lobate flows, and geologic setting where fine-grained materials (i.e., muds) are likely to have been deposited (Oehler and Allen, 2010, 2012a; Allen et al., 2013). Although the subsurface character of the martian features cannot be determined as it can be for terrestrial mud volcanoes (by seismic investigation; e.g., Oehler and Allen, 2012a), the martian mounds clearly are diapiric structures that have brought fluids to the surface of the planet from depth.

Mud volcanism on Earth is caused by fluid overpressure in areas of rapid accumulation of thick sediment piles (Kopf, 2002; Mazzini and Etiope, 2017). On Mars, overpressure has been suggested to explain several features in Gale Crater (Grotzinger et al., 2014; Rubin et al., 2017), but in Acidalia and Utopia, overpressure development could have been far more significant due to the tremendous volumes of sediment and fluid that flowed into those basins from the circumChryse and Elysium outflows, respectively (Carr, 1987; Rice and Edgett,1997; Tanaka et al., 2005).

In Acidalia, $\sim 40,000$ of the mud-volcano-like mounds are estimated (Fig. 7A) (Oehler and Allen, 2010), and thousands occur in Utopia. Given their great numbers in these basins, as well as their common association with giant polygons (Fig. 7B) and the enhanced seepage potential that giant-polygon fractures can add, Acidalia and Utopia could have been major sites of ancient methane release on Mars.

Although these mounds and giant polygons are all thought to be ancient (Hesperian-early Amazonian), they may have remained as open conduits throughout the Amazonian, acting as continuing sites for macro-seepage or microseepage. Potential methane in these basins could have been generated at depth by thermogenesis of buried organics (see Section 3.2.2) as well as by FTT reactions (see Sections 3.2.3 and 4.2.2). In addition, the proximity of these basins to potential magmatic heat derived from Tharsis and Elysium Mons could add to the potential for thermogenesis as well as the longevity and extent of liquid water.

These types of generation processes (thermogenesis and FTT reactions) would have been favored early in the history of Mars, when planetary heat flow and the potential for added heating from magmatism and large impacts would have been greatest. In more recent times, similar processes may have occurred, though at greater depths. Any produced deep methane could be stored in clathrates or possibly zeolites, or trapped in impact-related structures, sealed by permafrost in the proposed thick cryosphere (Clifford et al., 2010, 2013; Petitjean et al., 2014; Stuurman et al., 2016). Such gas could be expelled episodically when permafrost melts or sublimes, when clathrates are destabilized (by changes in temperature or pressure), or when zeolites are destabilized (perhaps by impacts, seismic activity, or erosion; Mousis et al., 2016).

Added interest in these sites is provided by the possibility that clasts brought to the surface by these mud-volcano-like structures could provide windows into subsurface habitats (as occurs in terrestrial mud volcano clasts; Fig. 8), and such habitats might contain evidence of microbial martian life (if it ever existed).

7.1.2. Ancient springs. Like mud volcanoes, springs can represent methane macro-seeps. On Mars, potential hot spring deposits have been described from Gusev Crater with ground-based data acquired by the Spirit rover (location shown in Fig. 2A) (Ruff et al., 2011; Ruff and Farmer, 2016). The deposits are composed of opaline silica with digitate textures reminiscent of features in hot springs/geysers in Chile. Ancient spring deposits have also been proposed in Vernal Crater, Arabia Terra (Allen and Oehler, 2008). These deposits include two light-toned, elliptical features, each with a bright central region and potential central vent (Fig. 9A-9B). The features are associated with an extensive system of aligned knobs (suggestive of fluid flow up dipping beds or faults) and have been compared to spring mounds in the Dalhousie Complex of Australia (Fig. 9C-9D). Other potential spring deposits have been described from Valles Marineris, some of the chaos terrains, and several additional large craters in Arabia Terra (Rossi et al., 2008). All of these could be candidates for methane 

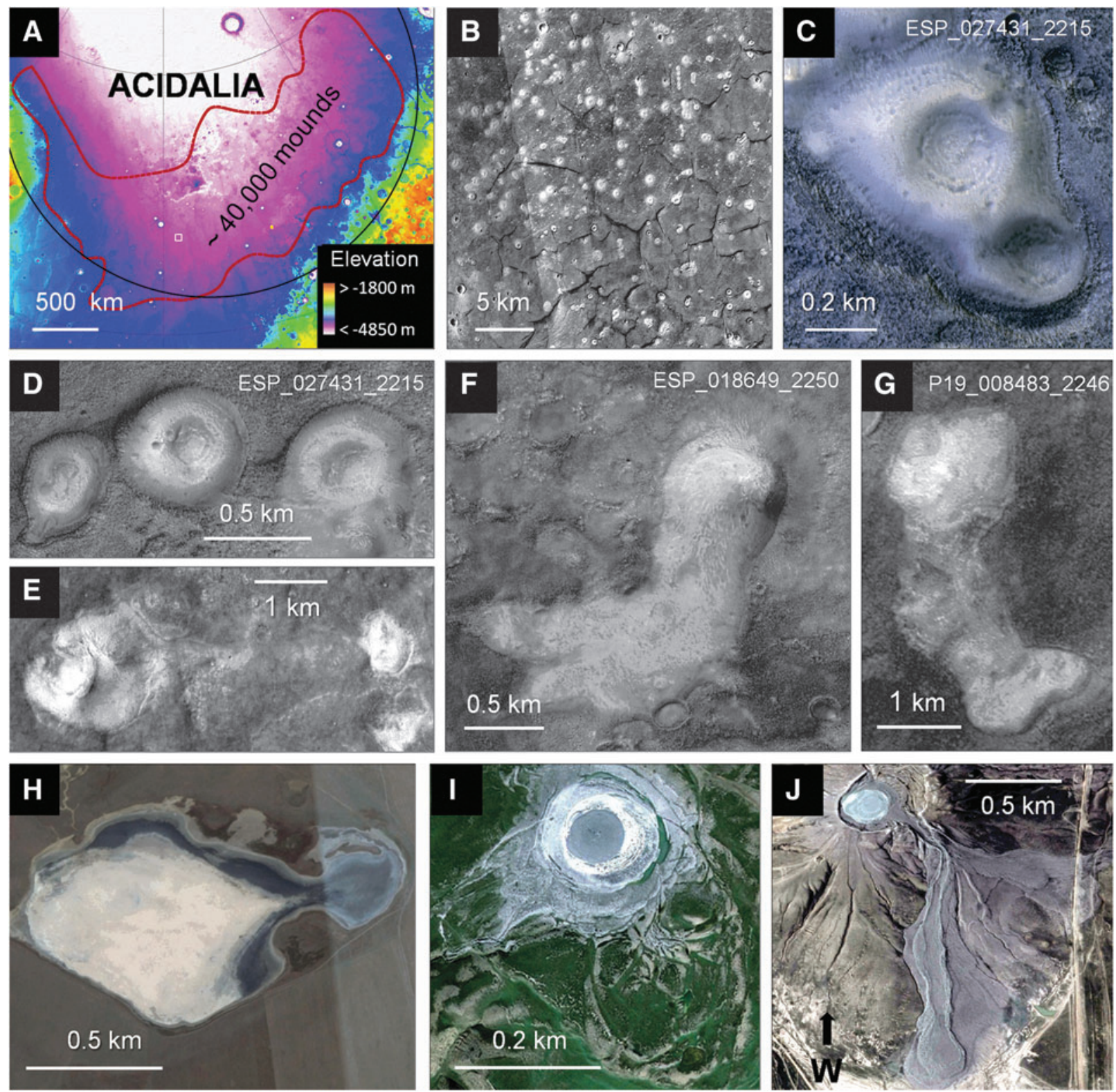

FIG. 7. Mud-volcano-like mounds in Acidalia and comparative mud volcanoes on Earth. Acidalia mounds (A-G): (A) Acidalia basin on MOLA basemap. Red outline is area within which $\sim 40,000$ mud-volcano-like mounds are estimated (Oehler and Allen, 2010). Small white square is the area of (B). (B) CTX mosaic of white square in (A), illustrating abundance of bright mounds and their association with giant polygons. (C-D) HiRISE images showing details of Acidalia mounds (moats and central depressions with concentric outlines). (E-G) Acidalia mounds with flows onto the plains: (E) Image from CTX mosaic of mound with flow to east; (F) HiRISE image; (G) CTX image. Terrestrial mud volcanoes $(\mathbf{H}-\mathbf{J})$ : (H) Google Earth image of Krasnopolskaya mud volcano in Crimea showing irregular limits of flow into depression; (I) Google Earth image of mud volcano in Azerbaijan showing concentrically bordered central area, surrounding moat, apronlike extensions of mud onto the plains, and older flows to the southeast. ( $\mathrm{J})$ Google Earth image of mud volcano in Azerbaijan showing concentrically bordered, central region and long, current flows to the east and northeast. North is up in (A-I) and to the right in (J). Centerpoints: (A) $46.22^{\circ} \mathrm{N}, 333.53^{\circ} \mathrm{E}$; (B) $40.56^{\circ} \mathrm{N}, 332.88^{\circ} \mathrm{E}$; (C) $44.02^{\circ} \mathrm{N}, 340.45^{\circ} \mathrm{E}$; (D) $41.23^{\circ} \mathrm{N}, 333.68^{\circ} \mathrm{E}$; (E) $46.72^{\circ} \mathrm{N}$, $340.35^{\circ} \mathrm{E}$; (F) $44.79^{\circ} \mathrm{N}, 331.72^{\circ} \mathrm{E}$; (G) $44.57^{\circ} \mathrm{N}, 317.13^{\circ} \mathrm{E}$; (H) $45.10^{\circ} \mathrm{N}, 36.25^{\circ} \mathrm{E}$; (I) $40.52^{\circ} \mathrm{N}, 49.02^{\circ} \mathrm{E}$; (J) $40.38^{\circ} \mathrm{N}, 49.62^{\circ} \mathrm{E}$. Image credits: Acidalia images: (A) MOLA basemap, NASA/JPL-Caltech/GSFC; (B) Google, NASA/USGS and NASA/JPL/ MSSS; (C-D, F) NASA/JPL/University of Arizona; (E) Google, NASA/USGS and NASA/JPL/MSSS; (G) NASA/JPL/MSSS. Earth images: (I) Google, 2016 Digital Globe; (H, J) Google, 2016 CNES/Astrium.

release, if connected through faults and fractures with sites of methane generation and accumulation at depth.

7.1.3. Flow structures along crater rims. Large crater rims could be sites of potential long-term methane seepage.
This is because crater rims are likely to be sites of both intense fracturing (Rodríguez et al., 2005) and enhanced hydrothermal flow. Studies by Newsom et al. (2001) and Newsom (2012) suggest that craters larger than $50 \mathrm{~km}$ in diameter (and possibly larger than $10 \mathrm{~km}$ in diameter) are 

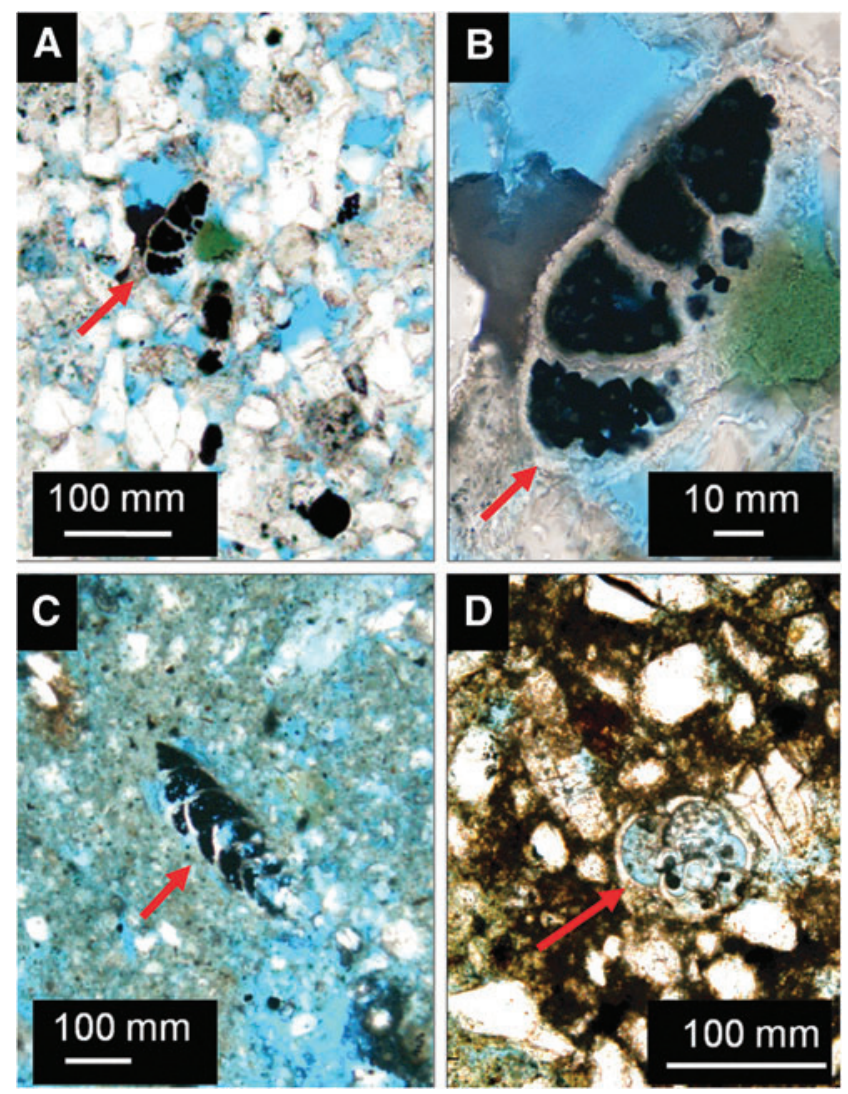

FIG. 8. Mud volcano as a window into a subsurface biosphere. Petrographic images of clasts from various terrestrial mud volcanoes in transmitted light, showing foram-like microfossils (arrows) in pore spaces. Blue is tinted epoxy that fills porosity. Black material in chambers of some of the microfossils is pyrite, which may suggest that sulfate-reducing bacteria also lived in microhabitats within porosity of the mud volcano clast. (A-B) Bozdag mud volcano, Azerbaijan. (C) Nirano mud volcano, Italy. (D) Wushanding mud volcano, Taiwan. Image credits: D.Z. Oehler.

predicted to have hydrothermal flow, particularly beyond the edges of the impact melt sheets (e.g., Fig. 6B) and toward the fractures associated with the rim.

An example of crater-rim flow structures is visible in the $120 \mathrm{~km}$ diameter ghost crater at the northern edge of the Chryse basin, where irregular knobs mark the rim (Fig. 10). The rounded and lobate character of these knobs, coupled with their absence from crater centers and from fluidized ejecta, suggests that they have been produced in association with hydrothermal flow up the crater rim (Oehler and Allen, 2011). Numerous ghost craters in southwest Acidalia Planitia and a few in southern Utopia Planitia show similar lobate features along their rims. Because of their locations in the major depo-centers of sedimentation and burial, these ghost craters may be in connection with methane generated at depth and could be reasonable sites for methane release.

7.1.4. Geothermal-volcanic areas. Associated with Tharsis and the other shield volcanoes on Mars are hundreds of smaller, satellite volcanoes, vents, and fissures (e.g., Hauber et al., 2011). While much of the martian volcanic activity was in the Noachian and Hesperian, several studies indicate that volcanism is a continuing process on Mars, with activity as recent as 2 million years ago (Hartmann et al., 1999; Neukum et al., 2004; Hartmann, 2005; Schumacher and Breuer, 2007; Hauber et al., 2011). Moreover, even apparently extinct volcanoes, by analogy with terrestrial examples, can still retain fluid circulation at a depth of a few kilometers (Dohm et al., 2008) and may even now exhale gas, albeit weakly, to the surface. Thus, both ancient and recent volcanism can provide sites for recurring gas exhalation to the surface. As noted (in Section 3.2.6), however, Earth magma contains trivial amounts of methane, and volcanoes are not important methane emitters.

\subsection{Potential zones of microseepage}

As discussed in Section 2.2.2, microseepage on Earth is the diffuse exhalation of gas (with no visible surface manifestation) that is widespread in association with hydrocarbon accumulations in sedimentary basins, especially along fault zones. Fault-related fissures on Earth are known to release methane, and these provide an analogue for potential sites of microseepage on Mars (Fig. 11). Below, we discuss potential pathways for microseepage at Nili Fossae, the dichotomy, young faults of the Cerberus Fossae, the Argyre impact basin, and other faulted areas.

7.2.1. Nili Fossae. Nili Fossae is a prime location for methane seepage. The large faults of the Nili Fossae, located at the dichotomy (Figs. 2B, 11A-11B), are likely related to the Isidis impact, as suggested by their concentric shape and position at the western edge of the Isidis basin. As a result, it is possible that the Nili Fossae may tap deep fluids that flowed up the impact-related rim faults as well as extensional faults associated with the dichotomy, and this combined flow from two separate sets of deep faults may provide enhanced potential for long-term flow of liquid water.

Consistent with these observations is speculation that methane from combined serpentinization/FTT reactions might have seeped through deep faults at Nili Fossae-speculation supported by the facts that the Nili Fossae occur in a zone where fractured serpentinized rocks have been observed (Ehlmann et al. 2010), where FTT reactions might have been promoted by necessary catalysts (e.g., Fig. 5B-5E and as described in Section 4.2.2), and where a methane plume was detected in 2003 by telescopic observations (Mumma et al., 2009). In addition, the location of Nili Fossae provides the possibility that its faults also could connect to methane generated by thermogenesis or FTT reactions at depth in the Isidis or Utopia basins. In all these cases, methane generated in the past would have to be trapped in sealed reservoirs, clathrates, or zeolites to preserve that methane as a potential source for present-day releases.

7.2.2. The dichotomy. Numerous extensional faults have been mapped along the dichotomy (Fig. 2B), and as noted above, these may provide long-term, deeply rooted pathways for fluid migration. A possible example of fluid flow related to the dichotomy is provided by orbital and Curiosity rover image data from Gale Crater (Fig. 12), which not only has an abundance of fractures and mineral-filled veins in its 

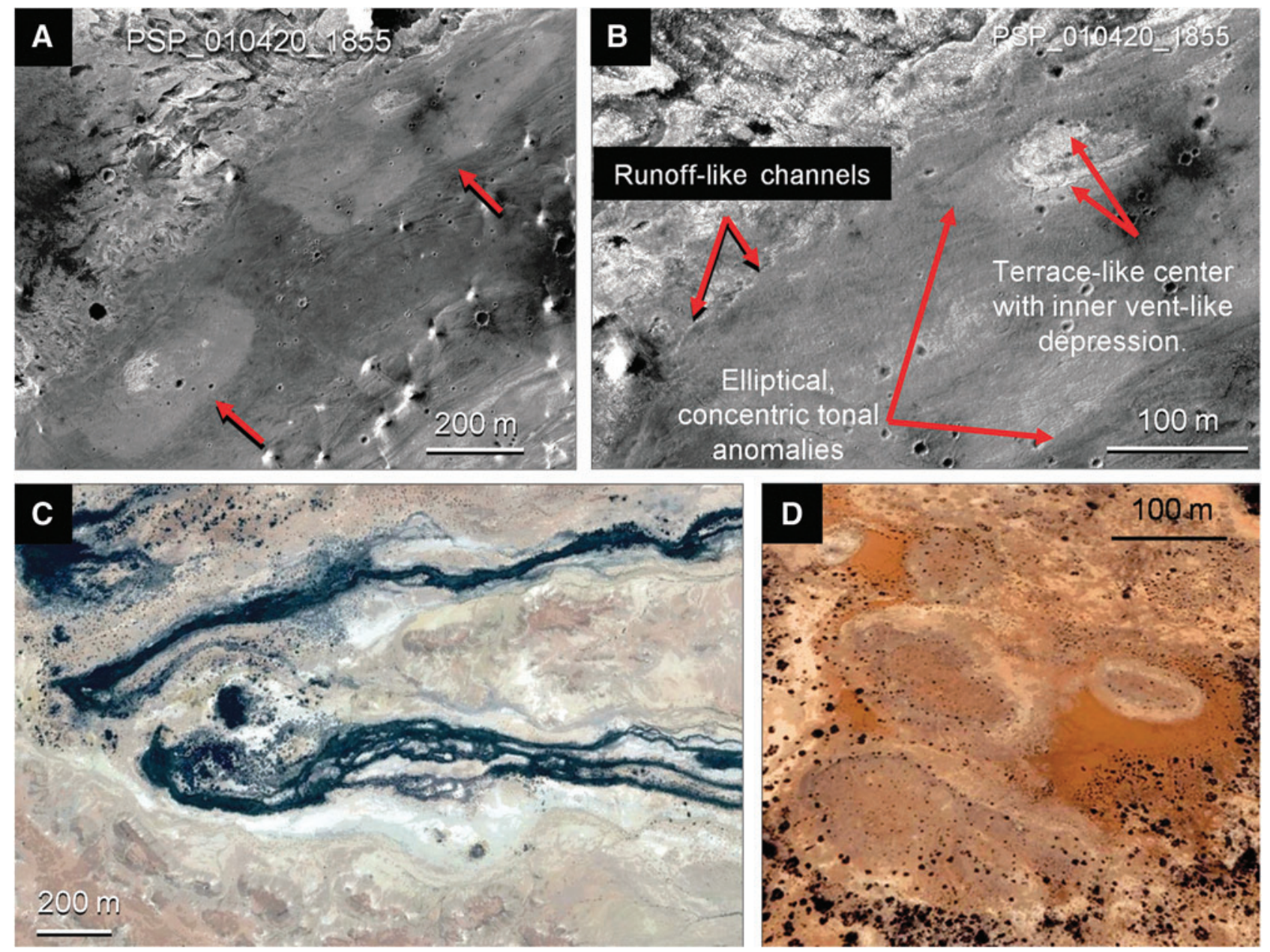

FIG. 9. Potential martian spring deposits (A-B) and comparisons with terrestrial spring mounds (C-D). (A) HiRISE image of elliptical albedo features (arrows) interpreted as spring deposits in Arabia Terra (Allen and Oehler, 2008). (B) HiRISE image of northeast feature from (A) illustrating details of morphology. (C) Active spring mound with apical vent in the Dalhousie spring complex in Australia. (D) Extinct spring mounds in the Dalhousie complex, showing elliptical shapes and concentric tonal halos. Centerpoints: (A) $5.64^{\circ} \mathrm{N}, 355.60^{\circ} \mathrm{E}$; (B) $5.64^{\circ} \mathrm{N}, 355.60^{\circ} \mathrm{E}$; (C) $26.45^{\circ} \mathrm{S}, 135.50^{\circ} \mathrm{E}$; (D) $26.51^{\circ} \mathrm{S}$; $135.50^{\circ} \mathrm{E}$. Image credits: (A-B) NASA/JPL/University of Arizona; (C-D) Google, 2016 CNES/Astrium.

sedimentary rocks (Grotzinger et al., 2014; Kronyak et al., 2015) but also an extensive network of boxwork deposits interpreted to reflect input of major volumes of groundwater early in Gale's history (Siebach and Grotzinger, 2014). Faults along the dichotomy may additionally tap methane generated at depth in the northern basins. Nili Fossae and Gale Crater are two examples located on the dichotomy; other faults mapped along this boundary may provide additional sites for future consideration.

7.2.3. Cerberus Fossae. The Cerberus Fossae (Figs. 2B, $11 \mathrm{C}-11 \mathrm{E})$ are a group of linear fissures in Elysium Planitia. They are radial to, and southeast of, Elysium Mons, extending for $\sim 1200 \mathrm{~km}$. They have been interpreted as graben faults, tension cracks or collapse structures related to tectonic stresses associated with dike intrusion (e.g., Vetterlein and Roberts, 2010; Taylor et al., 2013). These fissures are among the youngest volcano-tectonic features on Mars (between $\sim 10$ and 100 million years in age) and have been suggested to be the source of lavas and repeated, late Amazonian aqueous flooding onto the plains (Burr et al., 2002a, 2002b,
2009; Head, 2003; Head et al., 2003). Burr et al. (2002a) argued that the groundwater source for this flooding was at least several kilometers deep. If this is correct, the Cerberus Fossae must be major faults in communication with deep, liquid water in the plains, and as such, they would have the potential to tap any deep methane that may have been produced in Elysium Planitia.

7.2.4. The Argyre impact basin. Recent work has suggested that Argyre may be a site of long-lived, upward fluid flow through deep fractures formed by the Noachian ( $\sim 3.9 \mathrm{Ga}$ ) impact that created this $\sim 1200 \mathrm{~km}$ diameter basin (Soare et al., 2014). In addition, volcanism may be long-lived as well, with recent discovery of Argyre Mons, interpreted as a $3 \mathrm{Ga}$ volcanic structure with possible late Amazonian activity (Williams et al., 2017). And the TES analyses of Hamilton et al. (2003) and Koeppen and Hamilton (2008) identified northern Argyre as one of the areas with Chassigny-like concentrations of olivine $\left(\mathrm{Fo}_{68}\right)$. Together, these observations suggest that Argyre could have the ingredients for serpentinization to produce $\mathrm{H}_{2}$ and FTT- 

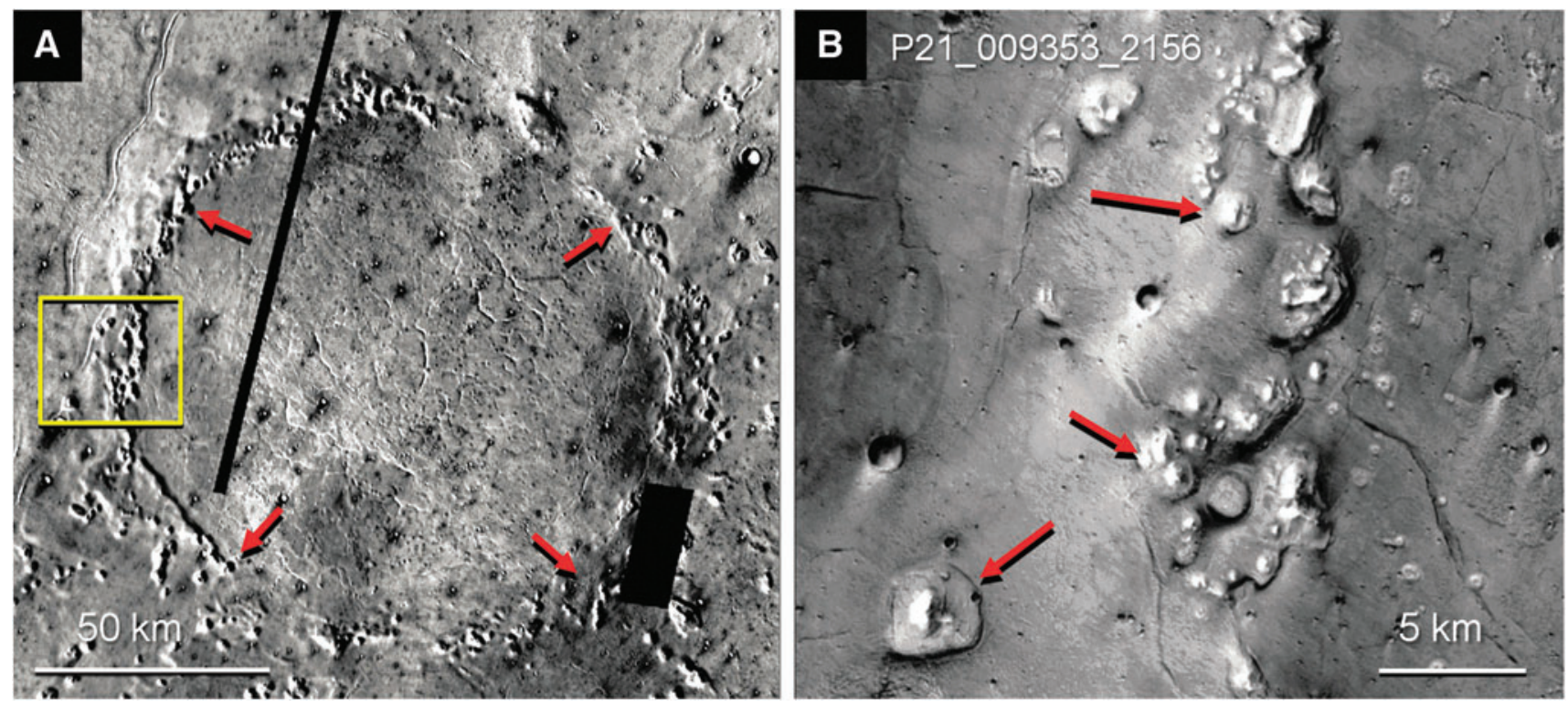

FIG. 10. Ghost crater in northern Chryse basin. (A) Thermal Emission Imaging System (THEMIS) daytime IR image mosaic. Yellow rectangle is area of $(\mathbf{B})$. Red arrows point to knobs along crater rim. (B) CTX image showing irregular and lobate nature of knobs along crater rim (arrows). Centerpoints: (A) $33.91^{\circ} \mathrm{N}, 322.94^{\circ} \mathrm{E}$; (B) $33.90^{\circ} \mathrm{N}, 38.16^{\circ} \mathrm{W}$. Image credits: (A) Google, NASA/USGS and NASA/JPL-Caltech/Arizona State University; (B) NASA/JPL/MSSS.
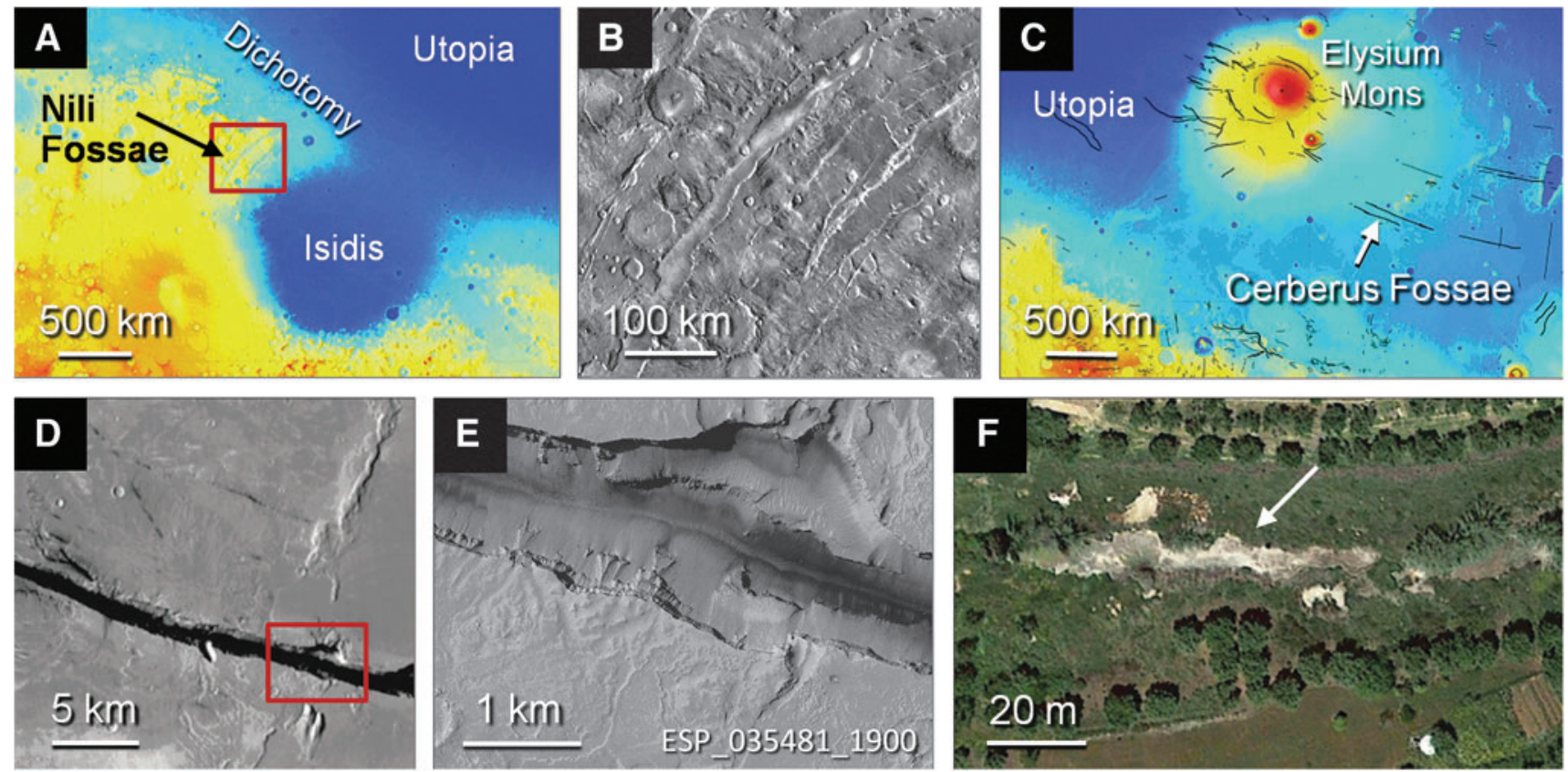

FIG. 11. Faults and fractures at Nili Fossae and Cerberus Fossae with comparison to a terrestrial gas-releasing fissure. (AB) Nili Fossae. (A) Regional image on basemap of MOLA topography. Elevation as in Fig. 2A. Red rectangle is the area of (B). (B) Daytime IR image mosaic from the THEMIS spectrometer on the Mars Odyssey orbiter. (C-E) Cerberus Fossae. (C) Regional image on basemap of MOLA topography, showing location of Cerberus Fossae. Elevation as in Fig. 2A. Scarps and faults are shown in black, using data from the US Geological Survey Global Map SIM3292(2014) and extensional faults provided in the USGS Mars Global GIS DVD version 2.1. Arrow points to approximate location of (D). (D) Closer view of one of the fractures of the Cerberus Fossae, on CTX mosaic. (E) HiRISE image showing sharp, unweathered edges of one of the Cerberus Fossae fractures and potential flow structures emanating from the southern edge. (F) Faros gas seep fissure, Greece. Arrow points to disturbed vegetation along fissure from which gas emanates. Centerpoints: (D) $10.04^{\circ} \mathrm{N}, 157.85^{\circ} \mathrm{E}$; (E) $9.96^{\circ} \mathrm{N}, 157.94^{\circ} \mathrm{E}$; (F) $37.64^{\circ} \mathrm{N}, 21.31^{\circ} \mathrm{E}$. Image credits: (A, C) MOLA basemap: NASA/JPL-Caltech/GSFC; (B) Google, NASA and NASA/JPL-Caltech/Arizona State University; (D) Google, NASA and NASA/JPL/MSSS; (E) NASA/JPL/University of Arizona; (F) Google, 2016 TerraMetrics. 

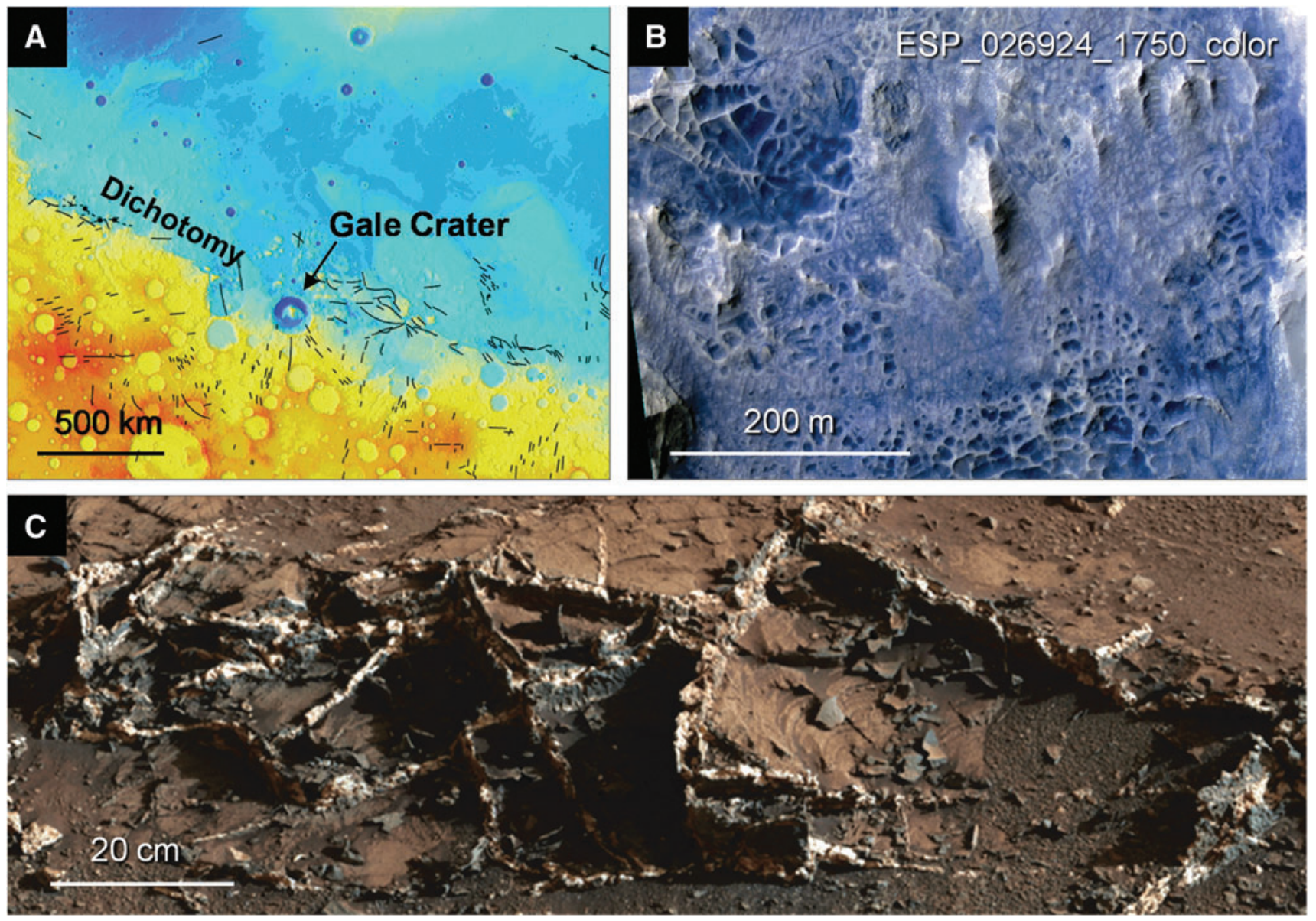

FIG. 12. Extensive fracturing and fluid movement in Gale Crater. (A) Regional view on basemap of MOLA topography, showing dichotomy and faults (black lines). Elevation as in Fig. 2A. (B) HiRISE image showing development of boxwork structures in Gale. Centerpoint, $4.84^{\circ} \mathrm{S}, 137.35^{\circ} \mathrm{E}$. (C) Garden City mineral-filled fractures in Gale Crater, shown in a portion of a mosaic of images taken by the Mastcam instrument on Curiosity over Sols 923-939, 944-948. Image credits: (A) MOLA basemap: NASA/JPL-Caltech/GSFC; (B) NASA/JPL/University of Arizona; (C) NASA/JPL-Caltech/MSSS.

Sabatier reactions to produce methane from that $\mathrm{H}_{2}$ (utilizing catalysts present in Chassigny-like materials). In addition, the large size and deep basin formed by the Argyre impact may provide potential for organic matter to have been concentrated and methane to have been subsequently produced by thermogenesis (as described in Section 3.2.2). Recent work also argues that permafrost may be common in the Argyre subsurface (Soare et al., 2014, 2017). That permafrost could provide storage for methane in clathrates, and it could also provide seals for trapped methane in subsurface reservoirs. Accordingly, Argyre is a candidate site of potential methane release.

7.2.5. Other areas. On Mars, additional sites for microseepage could include faults and fractures associated with (1) megabreccias (e.g., Fig. 4A), (2) local stresses (e.g., at Danielson Crater; Fig. 4B), (3) basin subsidence (e.g., at Aureum Chaos and perhaps other chaotic terrains on Mars; Spagnuolo et al., 2011), and (4) the giant polygons of the martian lowlands (e.g., Fig. 4C; Oehler and Allen, 2012b).

If any of these types of features overlie likely sites of methane generation, they could be considered as candidates for present-day methane release.

\section{Can Seepage Fluxes Support Observed Atmospheric $\mathrm{CH}_{4}$ Concentrations?}

The lifetime of methane on Mars is controlled by loss mechanisms (sinks), the conventional ones being photolysis by UV in the upper atmosphere (above $60 \mathrm{~km}$ ) and oxidation by $\mathrm{OH}$ and $\mathrm{O}\left({ }^{1} \mathrm{D}\right)$ at lower altitudes. The methane lifetime was estimated by Summers et al. (2002) to be $\sim 200-600$ years. More recent models suggest that the spatial and temporal changes of $\mathrm{CH}_{4}$ observed so far can only be explained by a greater sink (such as oxidation by hydrogen peroxide in the regolith), with a resulting shorter lifetime of 200 days or even a few hours near the surface (Lefèvre and Forget, 2009). If this is correct, it would imply that a larger source than previously estimated is required to replenish methane in the martian atmosphere.

The $\mathrm{CH}_{4}$ plume observed in the northern summer of 2003 was estimated to reflect an emission of about 19,000 tonnes $\mathrm{CH}_{4}$ year $^{-1}$ (Mumma et al., 2009) and possibly even 570,000 tonnes year ${ }^{-1}$ (Chizek et al., 2010). Examples of terrestrial analogues that might produce equivalent amounts of methane would include groups of large mud volcanoes (such as those in Azerbaijan, Romania, and coastal areas of the Black Sea) and regions of major 
hydrocarbon seeps (such as those onshore and offshore in many tectonically active petroleum provinces; Etiope, 2015). But, as discussed above, $\mathrm{CH}_{4}$ could also be released by microseepage from martian soil, even if macro-seeps or mud volcanoes are lacking or are not active. Assuming typical microseepage rates from soil in petroleum basins (about 4-40 tonnes $\mathrm{km}^{-2}$ year $^{-1}\left[10-100 \mathrm{mg} \mathrm{m}^{-2}\right.$ day $^{-1}$ ]; Etiope and Klusman, 2010), the plume-related 19,000 tonnes $\mathrm{CH}_{4}$ year ${ }^{-1}$ could be provided by a diffuse exhalation from an area of $500-5000 \mathrm{~km}^{2}$. And in order to produce the $10 \mathrm{ppbv}$ level in the martian atmosphere, assuming a photochemical lifetime of 340-600 years, a weak microseepage of 3-4 tonnes $\mathrm{km}^{-2}$ year $^{-1}\left(\sim 10 \mathrm{mg} \mathrm{m} \mathrm{m}^{-2}\right.$ day $^{-1}$ ) from only $30-90 \mathrm{~km}^{2}$ would be sufficient. If the entire $30,000 \mathrm{~km}^{2}$ of olivine-rich outcrop at Nili Fossae is assumed to exhale, then microseepage of $\sim 5$ tonnes $\mathrm{km}^{-2}$ year $^{-1}\left(15 \mathrm{mg} \mathrm{m}^{-2} \mathrm{day}^{-1}\right.$, as detected in several serpentinization sites on Earth; e.g., Etiope et al., 2013b, 2016) could account for the observed martian $\mathrm{CH}_{4}$ plume. Recent modeling of $\mathrm{CH}_{4}$ release on Mars indeed suggests that the northern summer 2003 plume was formed by a broad source rather than a point emission (Mischna et al., 2011), just as microseepage operates. Seasonal processes of adsorption and desorption in the regolith (Hu et al., 2016) may also control the final microseepage output leading to episodic releases of methane into the atmosphere.

\section{How to Detect Gas Seepage on Mars}

On Earth, natural gas seepage can be detected by several techniques that have been widely tested and used for hydrocarbon exploration and studies of greenhouse gas emissions (e.g., Philp and Crisp, 1982; Jones and Drozd, 1983; Klusman, 2006; Etiope and Klusman, 2010; Etiope, 2015). The techniques can be based on (a) direct measurements of gas above the ground (atmospheric and remote sensing measurements), in the ground (soil and shallow wells), and in water bodies (shallow aquifers, springs, lakes, seas, etc.) or (b) indirect measurements, looking for proxies of seepage, such as physical, chemical, and biological changes in soils, sediments, rocks, or vegetation induced by hydrocarbons (e.g., Schumacher, 1996). Methane from low flux seeps or microseepage may not be detected in atmospheric air because of winds and dispersion and dilution of the gas. In these cases, only specific ground-based investigations, such as soil-gas sampling and closed-chamber techniques or downhole analyses (e.g., Oehler and Sternberg, 1984), can detect seepage signals.

On Mars, the low and variable $\mathrm{CH}_{4}$ concentrations observed so far in the atmosphere may suggest that seepage is not as relevant as on Earth; alternatively, if significant martian gas exhalations exist, $\mathrm{CH}_{4}$ could be rapidly removed by strong consumption processes, such as oxidation by hydrogen peroxide (Lefèvre and Forget, 2009). So, the strength of a potential martian seepage signal not only would depend on the distance of the measured signal from the source of seepage, but it could also be decreased by oxidation as well as wind and advective mixing (Viscardy et al., 2016). It is because of these types of effects that even intense, but localized, methane seepage can be indistinguishable from atmospheric background, and measurements of methane $1 \mathrm{~m}$ above the ground, such as those performed by the Curiosity rover, may not be effective in revealing seepage that may be present.
Consequently, opportune procedures and techniques should be adopted to detect seepage on Mars. The best way to detect even weak and ephemeral exhalations of gas from the ground is to use sampling devices that operate directly at the soil-atmosphere interface or in the soil or subsoil, similar to those used on Earth (Fig. 13). We believe that soil-gas probes and accumulation chambers are viable techniques for Mars, as they are relatively simple and can be implemented using technology already developed and tested by NASA and ESA for martian exploration. For example, the team for NASA's Interior Exploration using Seismic Investigations, Geodesy and Heat Transport (InSight) mission developed the Heat Flow and Physical Properties probe $\left(\mathrm{HP}^{3}\right)$ for measurement of temperature down to $5 \mathrm{~m}$ in the subsoil (Spohn et al., 2012; Banerdt et al., 2013). A similar probe could be utilized to collect gas from the subsurface and analyze methane content by onboard instrumentation. Active instrument-deployment arms, similar to those designed for positioning a seismometer on InSight, can deploy closedchambers with diameters of $30-40 \mathrm{~cm}$, as is typically used for measuring gas flux from the soil on Earth (e.g., Etiope and Klusman, 2010). Closed-chambers, or accumulation chambers, allow the detection of higher concentrations of trace gases because they can accumulate gases in a closed system over a relatively short period of time (orders of minutes or a few hours, depending on the flux). And from the gas concentration buildup in the chamber, it is possible to evaluate the gas flux into the atmosphere. Chambers can be metallic, light, with a diameter of a few tens of centimeters and connected to a gas sampling and analysis system on board a lander or rover. The chamber can be reopened and closed for multiple measurements on the same spot.

The sampling of gas in the ground (or at the groundatmosphere interface) also has the advantage of limiting possible secondary chemical alterations that may occur in the martian atmosphere, such as isotopic fractionation due to oxidation, which may modify the original isotopic character of $\mathrm{CH}_{4}$, an important parameter for determining gas origin. A similar problem may arise from molecular fractionation, whereby methane/ethane ratios in the atmosphere can be different from those in the subsoil, because of differential oxidation of gaseous hydrocarbons. An additional, but not minor, advantage of ground measurements is the direct knowledge of the seepage location, information that can be elusive in atmospheric and remote sensing detections, where methane-rich plumes or layers can form far from actual sites of seepage (Viscardy et al., 2016). And knowing the geologic context of a seepage location is fundamental to understanding the potential origin of methane, as discussed in previous chapters.

Methane seepage on Mars could also be identified by indirect methods (e.g., secondary carbonate and sulfate minerals, electrical resistivity, radiometric and redox processes) and integrated with high-resolution images. However, since many factors other than seepage can induce these types of nearsurface anomalies, direct methane-detection remains the best way to detect the existence of gas seepage on Mars.

Based on all the above, we consider that these types of ground-based techniques should be applied on Mars preferably above or near faults or at the mud-volcano-like mounds, fluid-related mounds, ancient springs, and above sedimentary or ultramafic rocks, where FTT reactions are likely. 


\section{Macro-seepage Microseepage}

exhalations in mud volcano-like

mounds, crater rims, springs diffuse degassing along

faults and fractures

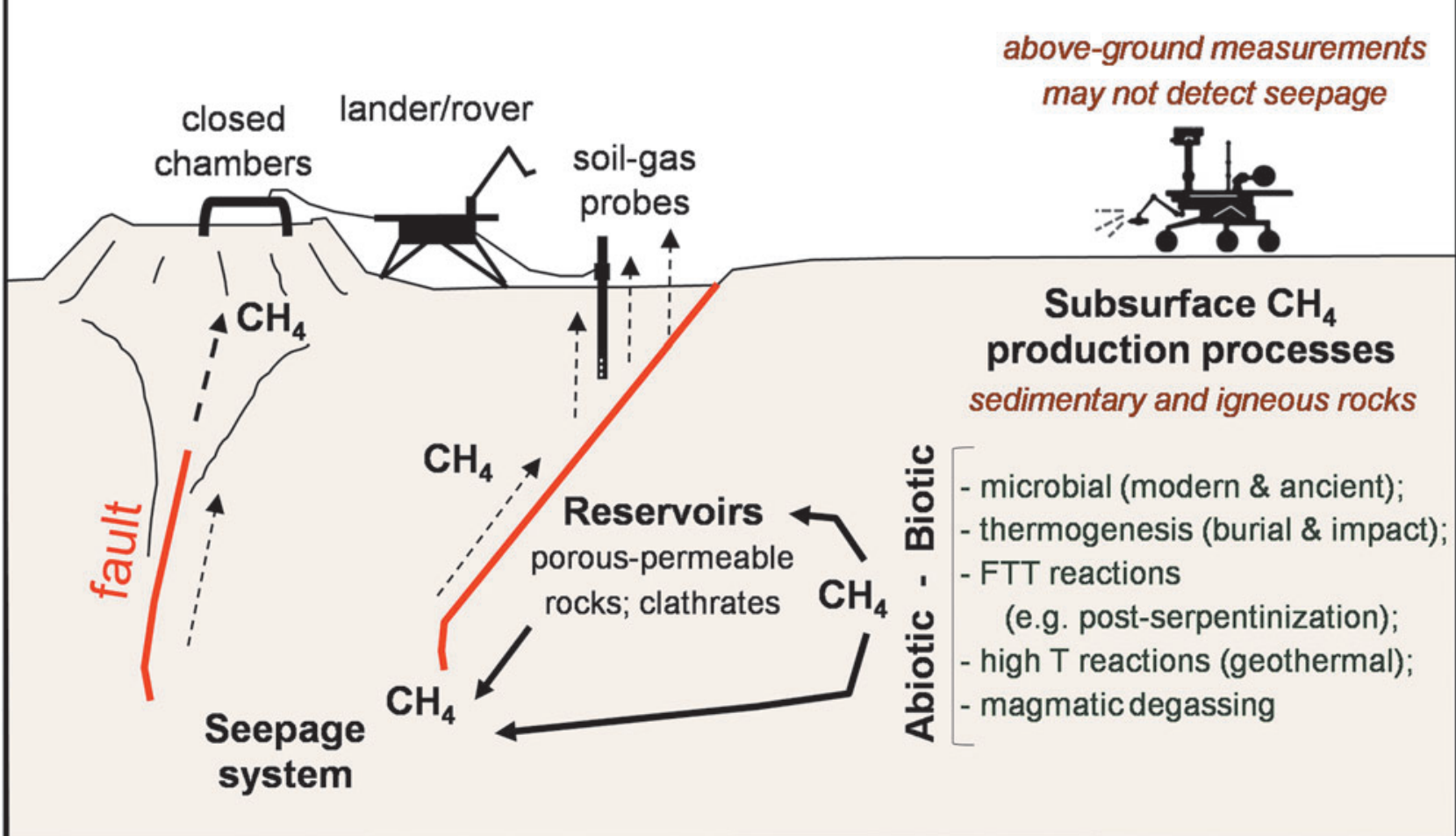

FIG. 13. Conceptual summary for $\mathrm{CH}_{4}$ seepage on Mars and recommended detection methods.

\section{Summary and Conclusions}

Knowing the processes that govern methane formation and release on Earth is a necessary step toward understanding why and where methane seepage might occur and be detected on Mars. In this work, we have integrated the extensive knowledge of terrestrial methane with martian geology to define potential mechanisms of methane generation, accumulation, and seepage on Mars.

Seven processes are identified that could generate methane in the subsurface of Mars. We emphasize that generated methane could be ancient or recent, and either biotic or abiotic. The generation processes could occur over a wide range of temperatures, in both lowland sedimentary basins and highland Noachian igneous rocks. To previous discussions, we have added potential generation by combinations of impact- and burial-thermogenesis of sedimentary organic matter, which itself could be abiotic (delivered by meteorites or IDPs) or biotic. The importance of metal catalysts for methanegenerating FTT reactions and the possibilities for trapping and storing ancient methane in the martian subsurface have also been described. Because early Mars likely had relatively high heat flows and intensity of large impactors, subsurface temperatures in the Noachian may have been particularly favorable for thermogenesis as well as FTT reactions. Together, then, these processes increase the possibility that significant methane could have formed in the subsurface of Mars, when the planet was young - a conclusion that may provide some support for the suggestion by Wordsworth et al. (2017) that methane release may have helped warm Mars early in its history.

Methane generated in the subsurface could be stored in clathrates; zeolites; and reservoir-quality rocks that are sealed by permafrost, evaporites, or shales. Episodic release of stored methane could occur when seals are breached or when clathrates or zeolites are destabilized. Methane would seep to the surface along faults and fractures and could develop as macro-seeps (such as mud volcanoes, springs, or gas vents, as on Earth) or microseepage (diffuse emanations lacking surface expression).

This analysis has highlighted the following sites on Mars as having special potential for methane release (Table 1). These could be priority candidates for analysis in future missions, using orbital or landed, ground-based data.

- Acidalia and Utopia basins: These basins are of particular interest for releasing methane produced from thermogenesis of abiotic organics. Additional methane could have been generated by thermogenesis of possibly biotic organics or perhaps by combined serpentinization/FTT reactions in buried Noachian crust. The proximity of Acidalia and Utopia to Tharsis and Elysium Mons, respectively, may have provided relatively high heat flows, enhancing the potential for thermogenesis or FTT catalysis. Trapped methane could be 
Table 1. Summary of Potential Methane Seepage Sites on Mars (References within Main Text)

\begin{tabular}{|c|c|c|c|}
\hline Type of Site & General areas & Specific areas & Comments \\
\hline $\begin{array}{l}\text { Mud-volcano- } \\
\text { like structures }\end{array}$ & $\begin{array}{l} \\
\\
\text { Lowlands areas, } \\
\text { Arabia Terra, } \\
\text { Valles Marineris }\end{array}$ & $\begin{array}{l} \\
\text { Isidis, Scandia, Chryse, } \\
\text { Crommelin and Firsoff } \\
\text { craters, Candor Chaos, } \\
\text { Candor and Coprates } \\
\text { Chasmata }\end{array}$ & $\begin{array}{l}\text { Locations in major depo-centers for fluid } \\
\text { and fine-grained sediment. Thermogenesis } \\
\text { potential by burial and impact heating. FTT } \\
\text { reactions possible in Noachian buried crust. } \\
\text { Proximity to volcanic edifices may enhance } \\
\text { heat flow and thermogenesis potential as } \\
\text { well as extent/duration of liquid water for } \\
\text { serpentinization and } \mathrm{H}_{2} \text { production for FTT } \\
\text { reactions. Permafrost seals could trap } \\
\text { ancient } \mathrm{CH}_{4} \text {. Clathrates and zeolites could } \\
\text { also store } \mathrm{CH}_{4} \text {. Mud-volcano-like mounds } \\
\text { and giant polygons provide conduits for } \\
\text { seepage. } \\
\text { Key sites for potential biotic or abiotic } \\
\text { CH } \boldsymbol{H}_{4} \text { seepage }\end{array}$ \\
\hline Ancient springs & Gusev crater & $\begin{array}{l}\text { Columbia Hills, adjacent to } \\
\text { "Home Plate", }\end{array}$ & $\begin{array}{l}\text { Data from Spirit rover. Opaline silica } \\
\text { with digitate textures; associated } \\
\text { volcanics; possible hot spring deposit. } \\
\text { Elliptical albedo features, circumferential } \\
\text { faults, aligned knobs suggestive of fluid } \\
\text { flow. } \sim 8 \mathrm{~km} \text { trend. Possible spring deposit. }\end{array}$ \\
\hline $\begin{array}{l}\text { Flow structures at } \\
\text { crater rims }\end{array}$ & Lowlands & $\begin{array}{l}\text { Many examples, } \\
\text { especially in ghost } \\
\text { craters in N. Chryse and } \\
\text { S. Acidalia }\end{array}$ & $\begin{array}{l}\text { Location on crater rims suggestive of } \\
\text { hydrothermal flow associated with } \\
\text { impacts. Example in N. Chryse also has } \\
\text { mud-volcano-like mounds and giant } \\
\text { polygons within crater. }\end{array}$ \\
\hline $\begin{array}{l}\text { Geothermal- } \\
\text { volcanic } \\
\text { centers }\end{array}$ & $\begin{array}{l}\text { Tharsis; Elysium } \\
\text { Mons, Syrtis } \\
\text { Major }\end{array}$ & $\begin{array}{l}\text { Satellite volcanoes, } \\
\text { vents, fissures }\end{array}$ & $\begin{array}{l}\text { Potential for recurring gas exhalation. } \\
\mathrm{CH}_{4} \text { content would be quite low based on } \\
\text { Earth analogs. }\end{array}$ \\
\hline $\begin{array}{l}\text { Microseepage } \\
\text { zones }\end{array}$ & $\begin{array}{l}\text { Faulted } \\
\text { sedimentary and } \\
\text { serpentinized } \\
\text { areas }\end{array}$ & $\begin{array}{l}\text { Dichotomy (e.g., Gusev } \\
\text { and Gale craters, } \\
\text { Nili Fossae) } \\
\text { Cerberus Fossae }\end{array}$ & $\begin{array}{l}\text { Relationship to Isidis impact and location } \\
\text { on the dichotomy provide potential for } \\
\text { deep fault conduits for seepage. Evidence } \\
\text { for past serpentinization; Chassigny-like } \\
\text { materials with FTT catalysts possible. } \\
\qquad \text { Key site for potential abiotic } \\
\qquad \boldsymbol{C H}_{4} \text { seepage } \\
\text { Deep fault potential, possibility to tap } \\
\mathrm{CH}_{4} \text { generated at depth in lowlands } \\
\text { basins. } \\
\text { Long fractures; recent fluid injection. } \\
\text { Deep source for liquid water. Possible site } \\
\text { for serpentinization but FTT catalysts } \\
\text { uncertain. } \\
\text { Long-lived fluid flow and volcanic } \\
\text { activity. Chassigny-like materials. } \\
\text { Serpentinization, FTT reactions, } \\
\text { organic thermogenesis possible. }\end{array}$ \\
\hline
\end{tabular}


sealed by the thick cryosphere or stored in clathrates or zeolites. And each of these areas has thousands of mudvolcano-like mounds, which could be sites of methane release and could provide clasts from the subsurface that could reveal potential endolithic habitats at depth.

- Nili Fossae and areas west of the Isidis impact basin: Nili Fossae stands out as a prime candidate for abiotic methane generation and seepage by the combination of potentially deep faults, serpentinization $\left(\mathrm{H}_{2}\right)$, carbonates $\left(\mathrm{CO}_{2}\right)$, and catalysts (e.g., ruthenium or other catalysts in chromitites) for the FTT-Sabatier reaction. Ancient methane would have to be sealed in conventional reservoirs/traps or stored in clathrates, and its episodic seepage to the atmosphere could explain the plumes detected by Mumma et al. (2009).

- Potential spring deposits: Spring deposits proposed in Gusev Crater, Vernal Crater, Valles Marineris, and other localities in Arabia Terra could be sites of past or present methane seepage (if located in regions of methane generation). Particularly interesting are the deposits in Vernal Crater, as these are associated with aligned knobs that are suggestive of fluid flow along faults or dipping beds.

- Cerberus Fossae: These fractures in Elysium Planitia have been interpreted as recently active faults and the source of repeated flooding events. Burr et al. (2002a) suggested that the source of groundwater for these floods was at least several kilometers deep, implying that the fractures of the Cerberus Fossae are likely in communication with deep, liquid water. If mechanisms exist for generating methane at depth, the Cerberus Fossae could be a site of present-day methane release.

- The Argyre impact basin: Recent studies suggest that the deep and large Argyre basin is an area of long-lived fluid flow from depth as well as potentially long-lived volcanic activity. In addition, TES analyses argue that northern Argyre could host Chassigny-like materials that would be expected to contain abundant olivine and the key catalysts for the FTT-Sabatier reactions. Thus, Argyre would be a prime candidate for methane production, via both FTT reactions after serpentinization and thermogenesis of organic materials. Methane would seep toward the surface through deep faults associated with the basin-forming impact. It could then be stored in clathrates within permafrost or in trapped reservoir-quality rocks sealed by permafrost.

We also note that even the lowest seepage fluxes on Earth could support the present-day atmospheric $\mathrm{CH}_{4}$ concentrations observed on Mars. Weak microseepage exhalations, widespread over a few thousand square kilometers, could explain background- and plume- $\mathrm{CH}_{4}$-anomalies, even if macro-seeps, such as mud volcanoes, are lacking or are not active.

Opportune procedures and techniques similar to those already available on Earth (soil-gas and closed-chamber methods) are recommended for use in the search for methane on Mars. Ground-based investigation (using rovers or landers) at sites of potential seepage can offer less ambiguous results than atmospheric measurements, because the ground-based methods allow capture of higher concentrations of $\mathrm{CH}_{4}$, which will be less affected by atmospheric fractionation and can be used for isotopic studies. Such investigations could produce the most definitive understanding of methane occurrence on the Red Planet.

\section{Acknowledgments}

This work had its inception at the "Methane on Mars" 2015-2016 workshops organized by the W.M. Keck Institute for Space Studies. We thank Drs. Stephen Clifford for providing insight into martian heat flow and geothermal conditions, John Parnell for discussions of potential impact-related thermal alteration of organics on Mars, Victoria Hamilton for permission to adapt figures from publications on martian olivine distribution and possible source regions for the Chassigny meteorite, Ken Edgett and Timothy Parker for discussions of martian sediment thicknesses, and Jennifer Blank for comments on an early draft of the manuscript. We are also grateful to reviewers, Drs. Adam Stevens and Angelo Pio Rossi, for their insightful suggestions that significantly improved the manuscript. D.Z.O. was supported by the Planetary Science Institute, Tucson, Arizona, USA; and G.E. was supported by the Istituto Nazionale di Geofisica e Vulcanologia, Sezione Roma 2, Roma, Italy.

\section{References}

Abramov, O. and Kring, D.A. (2005) Impact-induced hydrothermal activity on early Mars. J Geophys Res 110, doi:10 .1029/2005JE002453.

Abrams, M.A. (2005) Significance of hydrocarbon seepage relative to petroleum generation and entrapment. Mar Pet Geol 22:457-477.

Ahrens, T.H.J., Xia, K., and Coker, D. (2002) Depth of cracking beneath impact craters: new constraint for impact velocity. In Shock-Compression of Condensed Matter, edited by M.D. Furnish, N.N Thadhani, and Y. Horie, American Institute of Physics, New York, pp 1393-1396.

Allen, C.C. and Oehler, D.Z. (2008) A case for ancient springs in Arabia Terra, Mars. Astrobiology 8:1093-1112.

Allen, C.C., Oehler, D.Z., and Baker, D.M. (2009) Mud volcanoes-a new class of sites for geological and astrobiological exploration of Mars [abstract 1749]. In $40^{\text {th }}$ Lunar and Planetary Science Conference, Lunar and Planetary Institute, Houston.

Allen, C.C., Oehler, D., Etiope, G., Van Rensbergen, P., Baciu, C., Feyzullayev, A., Martinelli, G., Tanaka, K., and Van Rooij, D. (2013) Fluid expulsion in terrestrial sedimentary basins: a process providing potential analogs for giant polygons and mounds in the martian lowlands. Icarus 224:424-432.

Andrews-Hanna, J.C., Zuber, M.T., and Banerdt, W.B. (2008) The Borealis basin and the origin of the martian crustal dichotomy. Nature 453:1212-1215.

Atreya, S.K., Mahaffy, P.R., and Wong, A-S. (2007) Methane and related trace species on Mars: origin, loss, implications for life, and habitability. Planet Space Sci 55:358-369.

Banerdt, W.B., Golombek, M.P., and Tanaka, K.L. (1992) Stress and tectonics on Mars. In Mars, edited by H.H. Kieffer, B.M. Jakosky, C.W. Snyder, and M.S. Matthews, University of Arizona Press, Tucson, pp 249-297.

Banerdt, W.G., Smrekar, S., Lognonné, P., Spohn, T., Asmar, S.W., Banfield, D., Boschi, L., Christensen, U., Dehant, V., Folkner, W., Giardini, D., Goetze, W., Golombek, M., Grott, M., Hudson, T., Johnson, C., Kargl, G., Kobayashi, N., Maki, J., Mimoun, D., Mocquet, A., Morgan, P., Panning, M., Pike, W.T., 
Tromp, J., van Zoest, T., Weber, R., Wieczorek, M.A., Garcia, R., and Hurst, K. (2013) InSight: a discovery mission to explore the interior of Mars [abstract 1915]. In $44^{\text {th }}$ Lunar and Planetary Science Conference, Lunar and Planetary Institute, Houston.

Barlow, N.G. and Perez, C.B. (2003) Martian impact crater ejecta morphologies as indicators of the distribution of subsurface volatiles. J Geophys Res 108, doi:10.1029/2002JE002036.

Barton, R., Bird, K., García Hernández, J., Grajales-Nishimura, J.M., Herber, B., Weimer, P., Koeberl, C., Neumaier, M., Schenk, O., and Stark, J. (2010) High-impact reservoirs. Oilfield Review 21:14-29.

Baumgartner, R.J., Fiorentini, M.L., Baratous, D., Ferrière, Locmelis, M., Tomkins, A., and Sener, K.A. (2016) The variability of ruthenium in chromite from chassignite and olivine-phyric shergottite meteorites: new insights into the behavior of PGE and sulfur in martian magmatic systems. Meteorit Planet Sci 52:333-350.

Benner, S.A., Devine, K.G., Matveeva, L.N., and Powell, D.H. (2000) The missing organic molecules on Mars. Proc Natl Acad Sci USA 97:2425-2430.

Bibring, J.-P., Langevin, Y., Gendrin, A., Gondet, B., Poulet, F., Berthé, M., Soufflot, A., Arvidson, R., Mangold, N., Mustard, J.F., Drossart, P., and the OMEGA Team. (2005) Mars surface diversity as revealed by the OMEGA/Mars Express observations. Science 307:1576-1581.

Bish, D.L., Blake, D.F., Vaniman, D.T., Chipera, S.J., Morris, R.V., Ming, D.W., Treiman, A.H., Sarrazin, P., Morrison, S.M., Downs, R.T., Achilles, C.N., Yen, A.S., Bristow, T.F., Crisp, J.A., Morookian, J.M., Farmer, J.D., Rampe, E.B., Stolper, E.M., Spanovich, N.; MSL Science Team. (2013) X-ray diffraction results from Mars Science Laboratory: mineralogy of Rocknest at Gale Crater. Science 341, doi:10.1126/science.1238932.

Blamey, N.J.F., Parnell, J., McMahon, S., Mark, D.F., Tomkinson, T., Lee, M., Shivak, J., Izawa, M.R.M., Banerjee, N.R., and Flemming, R.L. (2015) Evidence for methane in martian meteorites. Nat Commun 6, doi:10.1038/ncomms8399.

Boston, P.J., Ivanov, M.V., and McKay, C.P. (1992) On the possibility of chemosynthetic ecosystems in subsurface habitats on Mars. Icarus 95:300-308.

Brown, A. (2000) Evaluation of possible gas microseepage mechanisms. Am Assoc Pet Geol Bull 84:1775-1789.

Burr, D.M., Grier, J.A., McEwen, A.S., and Kesszthelyi, L.P. (2002a) Repeated aqueous flooding from the Cerberus Fossae: evidence for very recently extant, deep groundwater on Mars. Icarus 159:53-73.

Burr, D.M., McEwen, A.S., and Sakimoto, W.E.H. (2002b) Recent aqueous floods from the Cerberus Fossae, Mars. Geophys Res Lett 29, doi:0.1029/2001GL013345.

Burr, D.M., Wilson, L., and Bargery, A.S. (2009) Floods from fossae: a review of Amazonian-aged extensional-tectonic megaflood channels on Mars. In Megaflooding on Earth and Mars, edited by D.M. Burr, P.A. Carling, and V.R. Baker, Cambridge University Press, Cambridge, UK.

Capaccioni, B., Taran, Y., Tassi, F., Vaselli, O., Mangani, G., and Macias, J.L. (2004) Source conditions and degradation processes of light hydrocarbons in volcanic gases: an example from El Chichón volcano (Chiapas State, Mexico). Chem Geol 206:81-96.

Carr, M.H. (1979) Formation of martian flood features by release of water from confined aquifers. $J$ Geophys Res 84:2995-3007.

Carr, M.H. (1987) Water on Mars. Nature 326:30-35.

Carr, M.H. and Head, J.W. (2010) Geologic history of Mars. Earth Planet Sci Lett 294:185-203.
Carrier, B.L., Beegle, L.W., Bhartia, R., and Abbey, W.J. (2015) Measurement of the depth of penetration of UV photons into Mars relevant rock samples to constrain habitability and limits of detection for the SHERLOC Mars 2020 instrument [abstract P43D-2138]. In AGU Fall Meeting, American Geophysical Union, Washington, DC.

Carter, J., Poulet, F., Bibring, J.-P., Mangold, N., and Murchie, S. (2013) Hydrous minerals on Mars as seen by the CRISM and OMEGA imaging spectrometers: updated global view. J Geophys Res: Planets 118:831-858.

Chan, M.A., Ormo, J., Murchie, S., Okubo, C.H., Komatsu, G., Wray, J.J., McGuire, P., and McGovern, J.A. (2010) Geomorphic knobs of Candor Chasms, Mars: new Mars Reconnaissance Orbiter data and comparisons to terrestrial analogs. Icarus 205:138-153.

Chastain, B.K. and Chevrier, V. (2007) Methane clathrate hydrates as a potential source for martian atmospheric methane. Planet Space Sci 55:1246-1256.

Chizek, M.R., Murphy, J.R., Kahre, M.A., Haberle, R.M., and Marzo, G.A. (2010) A shortlived trace gas in the martian atmosphere: a general circulation model of the likelihood of methane [abstract 1527]. In $41^{\text {st }}$ Lunar and Planetary Science Conference, Lunar and Planetary Institute, Houston.

Christensen, P.R., Bandfield, J.L., Bell, J.F., III, Gorelick, N., Hamilton, V.E., Ivanov, A., Jakosky, B.M., Kieffer, H.H., Lane, M.D., Malin, M.C., McConnochie, T., McEwen, A.S., McSween, H.Y., Jr., Mehall, G.L., Moersch, J.E., Nealson, K.H., Rice, J.W., Jr., Richardson, M.I., Ruff, S.W., Smith, M.D., Titus, T.N., and Wyatt, M.B. (2003) Morphology and composition of the surface of Mars: Mars Odyssey THEMIS results. Science 300:2056-2061.

Christensen, P.R., McSween, H.Y., Bandfield, J.L., Ruff, S.W., Rogers, A.D., Hamilton, V.E., Gorelick, N., Wyatt, M.B., Jakosky, B.M., Kieffer, H.H., Malin, M.C., and Moersch, J.E. (2005) Evidence for magmatic evolution and diversity on Mars from infrared observations. Nature 436: 504-509.

Clifford, S.M., Lasue, J., Heggy, E., Boisson, J., McGovern, P., and Max, M.D. (2010) Depth of the martian cryosphere: revised estimates and implications for the existence and detection of subpermafrost groundwater. J Geophys Res 115, doi:10.1029/2009JE003462.

Clifford, S.M., Costard, F., PetitJean, M., Mouginot, J., and Parker, T.J. (2013) Evidence for the widespread occurrence of massive ground ice in the northern plains of Mars: a potential relic of a former ocean? [abstract 2889]. In $44^{\text {th }}$ Lunar and Planetary Science Conference, Lunar and Planetary Institute, Houston.

Connerney, J.E.P., Acuna, M.H., Wasilewski, P., Ness, N.F., Rème, H., Mazelle, C., Vignes, D., Lin, R.P., Mitchell, D., and Cloutier, P. (1999) Magnetic lineations in the ancient crust of Mars. Science 284:794-798.

Davis, P.A. and Tanaka, K.L. (1995) Curvilinear ridges in Isidis Planitia, Mars - the result of mud volcanism? [abstract 1161]. In $26^{\text {th }}$ Lunar and Planetary Science Conference, Lunar and Planetary Institute, Houston.

Dohm, J.M., Barlow, N.G., Anderson, R.C., Williams, J.-P., Miyamoto, H., Ferris, J.C., Strom, R.G., Taylor, G.J., Fairén, A.G., Baker, V.R., Boynton, W.V., Keller, J.M., Kerry, K., Janes, D., Rodriguez, J.A.P., and Hare, T.M. (2007) Possible ancient giant basin and related water enrichment in the Arabia Terra province, Mars. Icarus 190:74-92.

Dohm, J.M., Anderson, R.C., Barlow, N.G., Miyamoto, H., Davies, A.G., Jeffrey Taylor, G., Baker, V.R., Boynton, 
W.V., Keller, J., Kerry, K., Janes, D., Fairén, A.G., SchulzeMakuch, D., Glamoclija, M., Marinangeli, L., Ori, G.G., Strom, R.G., Williams, J.-P., Ferris, J.C., Rodríguez, J.A.P., de Pablo, M.A., and Karunatillake, S. (2008) Recent geological and hydrological activity on Mars: the Tharsis/Elysium corridor. Planet Space Sci 56:985-1013.

Dohm, J.M., Spagnuolo, M.G., Williams, J.P., Viviano-Beck, C.E., Karunatillake, S., Álvarez, O., Anderson, R.C., Miyamoto, H., Baker, V.R., Fairén, A., Mahaney, W.C., Hare, T.M., Robbins, S.J., Niihara, T., Yin, A., Judice, T., Olsen, N., and Maruyama, S. (2015) The Mars plate-tectonic-basement hypothesis [abstract 1741]. In $46^{\text {th }}$ Lunar and Planetary Science Conference, Lunar and Planetary Institute, Houston.

Donofrio, R.R. (1998, May 11) North American impact structures hold giant field potential. Oil and Gas Journal 1998: 69-83.

Downey, M.W. (1984) Evaluating seals for hydrocarbon accumulations. Am Assoc Pet Geol Bull 68:1752-1763.

Ehlmann, B.L., Mustard, J.F., Poulet, F., Bishop, J.L., Brown, A.J., Calvin, W.M., Clark, R.N., Des Marais, D.J., Milliken, R.E., Roach, L.H., Roush, T.L., Swayze, G.A., and Wray, J.J. (2008) Orbital identification of carbonate-bearing rocks on Mars. Science 322:1828-1832.

Ehlmann, B.L., Mustard, J.F., Swayze, G.A., Clark, R.N., Bishop, J.L., Poulet, F., Des Marais, D.J., Roach, L.H., Milliken, R.E., Wray, J.L., Barnouin-Jha, O., and Murchie S.L. (2009) Identification of hydrated silicate minerals on Mars using MRO-CRISM: geologic context near Nili Fossae and implications for aqueous alteration. J Geophys Res: Planets 114, doi:10.1029/2009JE003339.

Ehlmann, B.L., Mustard, J.F., and Murchie, S.L. (2010) Geologic setting of serpentine deposits on Mars. Geophys Res Lett 37, doi:10.1029/2010GL042596.

Ehlmann, B.L., Mustard, J.F., Clark, R.N., Swayze, G.A., and Murchie, S.L. (2011) Evidence for low-grade metamorphism, diagenesis, and hydrothermal alteration on Mars from phyllosilicate mineral assemblages. Clays Clay Miner 59:359377.

Etiope, G. (2015) Natural Gas Seepage. The Earth's Hydrocarbon Degassing, Springer, Cham, Switzerland.

Etiope, G. (2017) Abiotic $\mathrm{CH}_{4}$ in ultramafic rocks: follow the Sabatier reaction rules. In Goldschmidt 2017, Paris.

Etiope, G. and Ionescu, A. (2015) Low-temperature catalytic $\mathrm{CO}_{2}$ hydrogenation with geological quantities of ruthenium: a possible abiotic $\mathrm{CH}_{4}$ source in chromitite-rich serpentinized rocks. Geofluids 15:438-452.

Etiope, G. and Klusman, R.W. (2010) Microseepage in drylands: flux and implications in the global atmospheric source/sink budget of methane. Glob Planet Change 72: 265-274.

Etiope, G. and Martinelli, G. (2002) Migration of carrier and trace gases in the geosphere: an overview. Physics of the Earth and Planetary Interiors 129:185-204.

Etiope, G. and Milkov, A.V. (2004) A new estimate of global methane flux from onshore and shallow submarine mud volcanoes to the atmosphere. Environ Geol 46:997-1002.

Etiope, G. and Schoell, M. (2014) Abiotic gas: atypical but not rare. Elements 10:291-296.

Etiope, G. and Sherwood Lollar, B. (2013) Abiotic methane on Earth. Rev Geophys 51:276-299.

Etiope, G., Fridriksson, T., Italiano, F., Winiwarter, W., and Theloke, J. (2007) Natural emissions of methane from geothermal and volcanic sources in Europe. Journal of Volcanology and Geothermal Research 165:76-86.
Etiope, G., Feyzullayev, A., and Baciu, C.L. (2009) Terrestrial methane seeps and mud volcanoes: a global perspective of gas origin. Mar Pet Geol 26:333-344.

Etiope, G., Nakada, R., Tanaka, K., and Yoshida, N. (2011a) Gas seepage from Tokamachi mud volcanoes, onshore Niigata basin (Japan): origin, post-genetic alterations and $\mathrm{CH}_{4}-$ $\mathrm{CO}_{2}$ fluxes. Appl Geochem 26:348-359.

Etiope, G., Oehler, D.Z., and Allen, C.C. (2011b) Methane emissions from Earth's degassing: implications for Mars. Planet Space Sci 59:182-195.

Etiope, G., Drobniak, A., and Schimmelmann, A. (2013a) Natural seepage of shale gas and the origin of "eternal flames" in the Northern Appalachian Basin, USA. Mar Pet Geol 43:178-186.

Etiope, G., Ehlmann, B.L., and Schoell, M. (2013b) Low temperature production and exhalation of methane from serpentinized rocks on Earth: a potential analog for methane production on Mars. Icarus 224:276-285.

Etiope, G., Vadillo, I., Whiticar, M.J., Marques, J.M., Carreira, P.M., Tiago, I., Benavente, J., Jiménez, P., and Urresti, B. (2016) Abiotic methane seepage in the Ronda peridotite massif, southern Spain. Appl Geochem 66:101-113.

Evans, B.W. (2004) The serpentine multisystem revisited. In Serpentine and Serpentinites: Mineralogy, Petrology, Geochemistry, Ecology, Geophysics, and Tectonics, edited by R.G. Coleman and W.G. Ernst, Bellwether Publishing for the Geological Society of America, Columbia, MD, pp 5-32.

Farrand, W.H., Gaddis, L.R., and Keszthlyi, L. (2005) Pitted cones and domes on Mars: observations in Acidalia Planitia and Cydonia Mensae using MOC, THEMIS, and TES data. J Geophys Res 110, doi:10.1029/2004JE002297.

Feinstein, L., Gautier, D., Heberger, M., Phillips, S., Lindsey, N., Ulrich, C., Drandt, A., and Foxall, W. (2015) Case study of the potential development of source rock in the Monterey Formation. In An Independent Scientific Assessment of Well Stimulation in California, Vol. 3, California Council on Science \& Technology Publications, Sacramento, CA, pp 112-198.

Fiebig, J., Woodland, A.B., Spangenberg, J., and Oschmann, W. (2007) Natural evidence for rapid abiogenic hydrothermal generation of $\mathrm{CH}_{4}$. Geochim Cosmochim Acta 71:3028-3039.

Flynn, G.J. (1996) The delivery of organic matter from the asteroids and comets to the early surface of Mars. Earth Moon Planets 72:469-474.

Flynn, G.J., Keller, L.P., Jacobsen, C., and Wirick, S. (2004) An assessment of the amount and types of organic matter contributed to the Earth by interplanetary dust. Adv Space Res 33:57-66.

Fonti, S. and Marzo, G.A. (2010) Mapping the methane on Mars. Astron Astrophys 512, doi:10.1051/0004-6361/200913178.

Formisano, V., Atreya, S., Encrenaz, T., Ignatiev, N., and Giuranna, M. (2004) Detection of methane in the atmosphere of Mars. Science 306:1758-1761.

Formolo, M. (2010) The microbial production of methane and other volatile hydrocarbons. In Handbook of Hydrocarbon and Lipid Microbiology, edited by K.N. Timmis, Springer, New York, pp 113-126.

Franchi, F., Rossi, A.P., Pondrelli, M., and Cavalazzi, B. (2014) Geometry, stratigraphy and evidences for fluid expulsion within Crommelin crater deposits, Arabia Terra, Mars. Planet Space Sci 92:34-48.

French, B. (1998) Traces of Catastrophe: A Handbook of Shock-Metamorphic Effects in Terrestrial Meteorite Impact 
Structures, LPI Contribution No. 954, Lunar and Planetary Institute, Houston.

Frey, H.V. (2004) Distribution of large visible and buried impact basins on Mars: comparison with free-air gravity, crustal thickness and magnetization models [abstract 1384]. In $35^{\text {th }}$ Lunar and Planetary Science Conference, Lunar and Planetary Institute, Houston.

Frey, H.V. (2006a) Impact constraints on, and a chronology for, major events in early Mars history. J Geophys Res 111, doi:10.1029/2005JE002449.

Frey, H.V. (2006b) Impact constraints on the age and origin of the lowlands of Mars. Geophys Res Lett 33, doi:10.1029/ 2005 GL024.

Frey, H.V. (2008) Ages of very large impact basins on Mars: implications for the Late Heavy Bombardment in the inner Solar System. Geophys Res Lett 35, doi:10.1029/2008GL033515.

Frey, H.V., Roark, J.H., Shockey, K.M., Frey, E.L., and Sakimoto, S.E.H. (2002) Ancient lowlands on Mars. Geophys Res Lett 29, doi:10.1029/2001GL013832.

Geminale, A., Formisano, V., and Sindoni, G. (2011) Mapping methane in martian atmosphere with PFS-MEX data. Planet Space Sci 59:137-148.

Golombek, M.P. and Phillips, R.J. (2009) Mars tectonics. In Planetary Tectonics, edited by T.R. Watters and R.A. Schultz, Cambridge University Press, Cambridge, UK, pp 183-232.

Grott, M., Baratous, D., Hauber, E., Sautter, V., Mustard, J., Gasnault, O., Ruff, S.W., Karato, S.-I., Debaille, V., Knapmeyer, M., Sohl, F., Van Hoolst, T., Breuer, D., Morschhauser, A., and Toplis, M.J. (2013) Long-term evolution of the martian crust-mantle system. Space Sci Rev 174:49-111.

Grotzinger, J.P. and Milliken, R.E. (2012) The sedimentary rock record of Mars: distribution, origins, and global stratigraphy. In Sedimentary Geology of Mars, SEPM Special Publication 102, edited by J.P. Grotzinger and R.E. Milliken, Society for Sedimentary Geology, Tulsa, OK, pp 1-48.

Grotzinger, J.P., Hayes, A.G., Lamb, M.P., and McLennan, S.M. (2013) Sedimentary processes on Earth, Mars, Titan, and Venus. In Comparative Climatology of Terrestrial Planets, edited by S.J. Mackwell, A.A. Simon-Miller, J.W. Harder, M.A. Bullock, and R. Dotson, University of Arizona, Tucson, pp 439-472.

Grotzinger, J.P., Sumner, D.Y., Kah, L.C., Stack, K., Gupta, S., Edgar, L., Rubin, D., Lewis, K., Schieber, J., Mangold, N., Milliken, R., Conrad, P.G., Des Marais, D., Farmer, J., Siebach, K., Calef, F., Hurowitz, J., McLennan, S.M., Ming, D., Vaniman, D., Crisp, J., Vasavada, A., Edgett, K.S., Malin, M., Blake, D., Geliert, R., Mahaffy, P., Wiens, R.C., Maurice, S., Grant, J.A., Wilson, S., Anderson, R.C., Beegle, L., Arvidson, R., Hallet, B., Sletten, R.S., Rice, M., Bell, J., Griffes, J., Ehlmann, B., Anderson, R.B., Bristow, T.F., Dietrich, W.E., Dromart, G., Eigenbrode, J., Fraeman, A., Hardgrove, C., Herkenhoff, K., Jandura, L., Kocurek, G., Lee, S., Leshin, L.A., Leveille, R., Limonadi, D., Maki, J., McCloskey, S., Meyer, M., Minitti, M., Newsom, H., Oehler, D., Okon, A., Palucis, M., Parker, T., Rowland, S., Schmidt, M., Squyres, S., Steele, A., Stolper, E., Summons, R., Treiman, A., Williams, R., Yingst, A., and the MSL Science Team. (2014) A habitable fluvio-lacustrine environment at Yellowknife Bay, Gale Crater, Mars. Science 343, doi:10.1126/science.1242777.

Guest, A. and Smrekar, S.E. (2005) Relaxation of the martian dichotomy boundary: faulting in the Ismenius Region and constraints on the early evolution of Mars. J Geophys Res 110, doi:10.1029/2005JE002504.
Hagerty, J.H. and Newsom, H.E. (2003) Hydrothermal alteration at the Lonar Lake impact structure, India: implications for impact cratering on Mars. Meteorit Planet Sci 38: 365-381.

Hamilton, V.E., Christensen, P.R., McSween, H.Y., Jr., and Bandfield, J.L. (2003) Searching for the source regions of martian meteorites using MGS TES: integrating martian meteorites into the global distribution of igneous materials on Mars. Meteorit Planet Sci 38:871-885.

Hanna, J.C. and Phillips, R.J. (2005) Hydrological modeling of the martian crust with application to the pressurization of aquifers. J Geophys Res 110, doi.org/10.1029/2004JE002330.

Hartmann, W.K. (2005) Martian cratering 8: isochron refinement and the history of martian geologic activity. Icarus 174:294-320.

Hartmann, W.K., Malin, M., McEwen, A., Carr, M., Soderblom, L., Thomas, P., Danielson, E., James, P., and Veverka, J. (1999) Evidence for recent volcanism on Mars from crater counts. Nature 397:586-589.

Hassler, D.M., Zeitlin, C., Wimmer-Schweingruber, R.F., Ehresmann, B., Rafkin, S., Eigenbrode, J.L., Brinza, D.E., Weigle, G., Böttcher, S., Böhm, E., Burmeister, S., Guo, J., Köhler, J., Martin, C., Reitz, G., Cucinotta, F.A., Kim, M.H., Grinspoon, D., Bullock, M.A., Posner, A., Gómez-Elvira, J., Vasavada, A., Grotzinger, J.P.; MSL Science Team. (2014) Mars' surface radiation environment measured with the Mars Science Laboratory's Curiosity rover. Science 343, doi:0.1126/science.1244797.

Hauber, E., Grott, M., and Kronberg, P. (2010) Martian rifts: structural geology and geophysics. Earth Planet Sci Lett 294:393-410.

Hauber, E., Brož, P., Jagert, F., Jodłowski, P., and Platz, T. (2011) Very recent and widespread basaltic volcanism on Mars. Geophys Res Lett 38, doi:10.1029/2011GL047310.

Head, J.W. (2003) Generation of recent massive water floods at Cerberus Fossae, Mars by dike emplacement, cryospheric cracking, and confined aquifer groundwater release. Geophys Res Lett 30, doi:10.1029/2003GL017135.

Head, J.W., Kreslavsky, M.A., and Pratt, S. (2002) Northern lowlands of Mars: evidence for widespread volcanic flooding and tectonic deformation in the Hesperian period. $J$ Geophys Res 107, doi:10.1029/2000JE001445.

Head, J.W., Wilson, L., and Mitchell, K.L. (2003) Generation of recent massive water floods at Cerberus Fossae, Mars by dike emplacement, cryospheric cracking, and confined aquifer groundwater release. Geophys Res Lett 30, doi:10.1029/ 2003 GL017135.

Hoefen, T.M., Clark, R.N. Bandfield, J.L., Smith, M.D., Pearl, J.C., and Christensen, P.R. (2003) Discovery of olivine in the Nili Fossae region of Mars. Science 302:627-630.

Holm, N.G., Oze, C., Mousis, O., Waite, J.H., and GuilbertLepoutre, A. (2015) Serpentinization and the formation of $\mathrm{H}_{2}$ and $\mathrm{CH}_{4}$ on celestial bodies (Planets, Moons, Comets). Astrobiology 15:587-600.

Hovland, M. and Judd, A.G. (1988) Seabed Pockmarks and Seepages: Impact on Geology, Biology and the Marine Environment, Graham and Trotman, London.

Hu, R., Bloom, A.A., Gao, P., Miller, C.E., and Yung, Y.L. (2016) Hypotheses for near-surface exchange of methane on Mars. Astrobiology 16:539-550.

Hunt, J.M. (1996) Petroleum Geochemistry and Geology, W.H. Freeman and Co., New York.

Irwin, R.P., III, and Grant, J.A. (2013) Geologic Map of MTM -15027, -20027, -25027, and -25032 Quadrangles, Margaritifer Terra Region of Mars, U.S. Geological Survey Scientific 
Investigations Map 3209, pamphlet 11 p., 1 sheet, scale 1:1,000,000. Available online at http://dx.doi.org/10.3133/ $\operatorname{sim} 3209$

Ivanov, B.A. and Pierazzo, E. (2011) Impact cratering in $\mathrm{H}_{2} \mathrm{O}$ bearing targets on Mars: thermal field under craters as starting conditions for hydrothermal activity. Meteorit Planet Sci 46:601-619.

Ivanov, M.A., Hiesinger, H., Erkeling, G., and Reiss, D. (2014) Mud volcanism and morphology of impact craters in Utopia Planitia on Mars: evidence for the ancient ocean. Icarus 228: 121-140.

Jablonski, S., Rodowicz, P., and Kukaszewicz, M. (2015) Methanogenic archaea database containing physiological and biochemical characteristics. Int J Syst Evol Microbiol 65: 1360-1368.

Jones, J.H., Neal, C.R., and Ely, J.C. (2003) Signatures of the highly siderophile elements in the SNC meteorites and Mars: a review and petrologic synthesis. Chem Geol 196:21-41.

Jones, V.T. and Drozd, R.J. (1983) Prediction of oil or gas potential by near-surface geochemistry. Am Assoc Pet Geol Bull 67:932-952.

Keppler, F., Vigano, I., McLeod, A., Ott, U., Fruchtl, M., and Rockmann, T. (2012) Ultlraviolet-radiation-induced methane emissions from meteorites and the martian atmosphere. Nature 486:93-96.

Kite, E.S., Hovius, N., Hillier, J.K., and Besserer, J. (2007) Candidate mud volcanoes in the Northern Plains of Mars [abstract V13B-1346]. In AGU Fall Meeting, American Geophysical Union, Washington, DC.

Klusman, R.W. (2006) Detailed compositional analysis of gas seepage at the National Carbon Storage Test Site, Teapot Dome, Wyoming, USA. Appl Geochem 21:1498-1521.

Klusman, R.W., Leopold, M.E., and LeRoy, M.P. (2000) Seasonal variation in methane fluxes from sedimentary basins to the atmosphere: results from chamber measurements and modeling of transport from deep sources. J Geophys Res: Atmospheres 105:24661-24670.

Knapmeyer, M., Oberst, J., Hauber, E., Wählisch, M., Deuchler, C., and Wagner, R. (2006) Working models for spatial distribution and level of Mars' seismicity. J Geophys Res 111, doi:10.1029/2006JE002708.

Koeppen, W.C. and Hamilton, V.E. (2008) Global distribution, composition, and abundance of olivine on the surface of Mars from thermal infrared data. J Geophys Res 113, doi:10.1029/ 2007JE002984.

Komar, P.D. (1979) Comparisons of the hydraulics of water flows in martian outflow channels with flows of similar scale on Earth. Icarus 37:156-181.

Komar, P.D. (1980) Modes of sediment transport in channelized water flows with ramifications to the erosion of the martian outflow channels. Icarus 42:317-329.

Komatsu, G. (2010) A possible mud volcano field in Chruse Planitia, Mars [EPSC2010-131]. In EPSC Abstracts, Vol. 5, European Planetary Science Congress.

Komatsu, G., Okubo, C.H., Wray, J.J., Ojha, L., Cardinale, M., Murana, A., Orosei, R., Chan, M.A., Ormö, J., and Gallagher, R. (2016a) Small edifice features in Chryse Planitia, Mars: assessment of a mud volcano hypothesis. Icarus 268:56-75.

Komatsu, G., Okubo, C.H., Wray, J.J., Ojha, L., Cardinale, M., Murana, A., Orosei, R., Chan, M.A., Ormö, J., and Gallagher, R. (2016b) Probable mud volcanoes in Chryse Planitia, Mars: updates on morphological, sedimentological and spectral studies [abstract 1067]. In $47^{\text {th }}$ Lunar and Planetary Science Conference, Lunar and Planetary Institute, Houston.
Kopf, A.J. (2002) Significance of mud volcanism. Rev Geophys 40:1-52.

Krasnopolsky, V.A. (2005) A sensitive search for $\mathrm{SO}_{2}$ in the martian atmosphere: implications for seepage and origin of methane. Icarus 178:487-492.

Krasnopolsky, V.A., Maillard, J.P., and Owen T.C. (2004) Detection of methane in the martian atmosphere: Evidence for life? Icarus 172:537-547.

Kreslavsky, M.A. and Head, J.W., III (2002) Fate of outflow channel effluents in the northern lowlands of Mars: the Vastitas Borealis Formation as a sublimation residue from frozen ponded bodies of water. J Geophys Res 107, doi:10 .1029/2001JE001831.

Kronyak, R.E., Kah, L.C., Grotzinger, J.P., Fisk, M.R., Sumner, D.Y., Nachon, M., Mangold, N., Blaney, D.L., Rapin, W., and Wiens, R.C. (2015) Garden City: a complex vein system observed by the Curiosity rover at Pahrump Hills, Gale Crater, Mars [paper No. 71-13]. In 2015 GSA Annual Meeting, Baltimore, MD.

Kumar, P.S. and Kring, D.Z.A. (2008) Impact fracturing and structural modification of sedimentary rocks at Meteor Crater, Arizona. J Geophys Res 113, doi:10.1029/2008JE003115.

Lasue, J., Quesnel, Y., Langlais, B., and Chassefière, E. (2015) Methane storage capacity of the early martian cryosphere. Icarus 260:205-214.

Lefèvre, F. and Forget, F. (2009) Observed variations of methane on Mars unexplained by known atmospheric chemistry and physics. Nature 460:720-723.

Link, W.K. (1952) Significance of oil and gas seeps in world oil exploration. Am Assoc Pet Geol Bull 36:1505-1540.

Llorca, J. (2004) Organic matter in meteorites. Int Microbiol 7:239-248.

Macdonald, A.H. and Fyfe, W.S. (1985) Rate of serpentinization in seafloor environments. Tectonophysics 116:123-135.

MacElvain, R. (1969) Mechanics of gaseous ascension through a sedimentary column. In Unconventional Methods in Exploration for Petroleum and Natural Gas, edited by W.B. Heroy, Southern Methodist University Press, Dallas, TX, pp 15-28.

Macgregor, D.S. (1993) Relationships between seepage, tectonics and subsurface petroleum reserves. Mar Pet Geol 10:606-619.

MacKinnon, D.J. and Tanaka, K.L. (1989) The impact martin crust: structure, hydrology, and some geologic implications. J Geophys Res: Solid Earth 94:17359-17370.

Malin, M.C. and Edgett, K.S. (2000) Sedimentary rocks of early Mars. Science 290:1927-1937.

Malmqvist, L. and Kristiansson, K. (1985) A physical mechanism for the release of free gases in the lithosphere. Geoexploration 23:447-453.

Marinova, M.M., Aharonson, O., and Asphaug, E. (2008) Mega-impact formation of the Mars hemispheric dichotomy. Nature 453:1216-1219.

Max, M., Johnson, A., and Clifford, S. (2011) Methane hydrate on Mars: a resource-rich stepping stone to the outer planets? In Proceedings of the $7^{\text {th }}$ International Conference on Gas Hydrates (ICGH 2011), Edinburgh, Scotland.

Max, M.D., Clifford, S.M., and Johnson, A.H. (2013) Hydrocarbon system analysis for methane hydrate exploration on Mars. In Energy Resources for Human Settlement in the Solar System and Earth's Future in Space, AAPG Memoir 101, edited by W.A. Ambrose, J.F. Reilly II, and D.C. Peters, American Association of Petroleum Geologists, Tulsa, OK, pp 99-114. 
Mazzini, A. and Etiope, G. (2017) Mud volcanism: an updated review. Earth-Science Reviews 168:81-112.

McCollom, T.M. and Seewald, J.S. (2007) Abiotic synthesis of organic compounds in deep-sea hydrothermal environments. Chem Rev 107:382-401.

McGovern, P.J., Solomon, S.C., Smith, D.E., Zuber, M.T., Simons, M., Wieczorek, M.A., Phillips, R.J., Neumann, G.A., Aharonson, O., and Head, J.W. (2002) Localized gravity/topography admittance and correlation spectra on Mars: implications for regional and global evolution. J Geophys Res: Planets 107, doi:10.1029/2002JE001854.

McGovern, P.J., Solomon, S.C., Smith, D.E., Zuber, M.T., Simons, M., Wieczorek, M.A., Phillips, R.J., Neumann, G.A., Aharonson, O., and Head, J.W. (2004) Correction to "Localized gravity/topography admittance and correlation spectra on Mars: implications for regional and global evolution." $J$ Geophys Res 109, doi:10.1029/2004JE002286.

McGowan, E. (2009) Spatial distribution of putative water related features in Southern Acidalia/Cydonia Mensae, Mars. Icarus 202:78-89.

McGowan, E.M. and McGill, G.E. (2010) The Utopia/Isidis overlap; possible conduit for mud volcanism [abstract 1070]. In $41^{\text {st }}$ Lunar and Planetary Science Conference, Lunar and Planetary Institute, Houston.

McMahon, S. and Parnell, J. (2014) Weighing the deep continental biosphere. FEMS Microbial Ecol 87:113-120.

McSween, H.Y., Jr., Labotka, T.C., and Viviano-Beck, C.E. (2015) Metamorphism in the martian crust. Meteorit Planet Sci 50:590-603.

Melosh, H.J. (1989) Impact Cratering: A Geologic Process, Oxford University Press, New York.

Michalski, J. and Niles, P. (2010) Deep crustal carbonate rocks exposed by meteor impact on Mars. Nat Geosci 3: 751-755.

Mischna, M.A., Allen, M., Richardson, M.I., Newman, C.E., and Toigo, A.D. (2011) Atmospheric modelling of Mars methane surface releases. Planet Space Sci 59:227-237.

Moores, J.E. and Schuerger, A.C. (2012) UV degradation of accreted organics on Mars: IDP longevity, surface reservoir of organics, and relevance to the detection of methane in the atmosphere. J Geophys Res 117, doi:10.1029/2012JE004060.

Mouginot, J., Pommerol, A., Beck, P., Kofman, W., and Clifford, S.M. (2012) Dielectric map of the martian northern himisphere and the nature of plain filling materials. Geophys Res Lett 39, doi:10.1029/2011GL050286.

Mousis, O., Simon, J.-M., Bellat, J.-P., Schmidt, F., Bouley, S., Chassefière, E., Sautter, V., Quesnel, Y., Picaud, S., and Lectez, S. (2016) Martian zeolites as a source of atmospheric methane. Icarus 278:1-7.

Mumma, M.J., Villanueva, G.L., Novak, R.E., Hewagame, T., Bonev, B.P., DiSanti, M.A., Mandell, A.M., and Smith, M.D. (2009) Strong release of methane on Mars in northern summer 2003. Science 323:1041-1045.

Muñoz Caro, G.M., Mateo-Martím, E., and Martínez-Frías, J. (2006) Near-UV transmittance of basalt dust as an analog of the martian regolith: implications of sensor calibration and astrobiology. Sensors 6:688-696.

Mustard, J.F. and Tarnas, J.D. (2017) Hydrogen production from the upper $15 \mathrm{~km}$ of martian crust via serpentinization: implications for habitability [abstract 2384]. In $48^{\text {th }}$ Lunar and Planetary Science Conference, Lunar and Planetary Institute, Houston.

Mustard, J.F., Poulet, F., Gendrin, A., Bibring, J.-P., Langevin, Y., Gondet, B., Mangold, N., Bellucci, G., and Altieri, F.
(2005) Olivine and pyroxene diversity in the crust of Mars. Science 307:1594-1597.

Neukum, G., Jaumann, R., Hoffmann, H., Hauber, E., Head, J.W., Basilevsky, A.T., Ivanov, B.A., Verner, S.C., Van Gasselt, S., Murray, J.B., McCord, T., and the HRSC CoInvestigator Team. (2004) Recent and episodic volcanic and glacial activity on Mars revealed by the High Resolution Stereo Camera. Nature 432:971-979.

Newsom, H.E. (2012) Impact crater hydrothermal processes in terrestrial analog craters and their implications for phyllosilicates in impact craters on Mars [abstract 7065]. In Third Conference on Early Mars: Geologic, Hydrologic, and Climatic Evolution and the Implications for Life, Lunar and Planetary Institute, Houston.

Newsom, H.E., Hagerty, J.J., and Thorsos, I.E. (2001) Location and sampling of aqueous and hydrothermal deposits in martian impact craters. Astrobiology 1:71-88.

Niles, P.B., Catling, D.C., Berger, G., Chassefière, E., Ehlmann, B.L., Michalski, J.R., Morris, R., Ruff, S., and Sutter, B. (2013) Geochemistry of carbonates on Mars: implications for climate history and nature of aqueous environments. Space Sci Rev 174:301-328.

Ody, A., Poulet, F., Langevin, Y., Bibring, J.-P., Bellucci, G., Altieri, F., Gondet, B., Vincendon, M., and Carter, J. (2012) Global maps of anhydrous mineral at the surface of Mars from OMEGA/Mex. J Geophys Res 117, doi:10.1029/2012JE004117.

Ody, A., Poulet, F., Bibring, J.-P., Loizeau, D., Carter, J., Gondet, B., and Langevin, Y. (2013) Global investigation of olivine on Mars: insights into crust and mantle compositions. J Geophys Res: Planets 118:234-262.

Ody, A., Quantin, C., and Poulet, F. (2014) An olivine ocean in the northern plains of Mars [abstract 2848]. In 45 ${ }^{\text {th }}$ Lunar and Planetary Science Conference, Lunar and Planetary Institute, Houston.

Oehler, D.Z. and Allen, C.C. (2009) Mud volcanoes in the martian lowlands: potential windows to fluid-rich samples from depth [abstract 1034]. In 40 ${ }^{\text {th }}$ Lunar and Planetary Science Conference, Lunar and Planetary Institute, Houston.

Oehler, D.Z. and Allen, C.C. (2010) Evidence for pervasive mud volcanism in Acidalia Planitia, Mars. Icarus 208: 636-657.

Oehler, D.Z. and Allen, C.C. (2011) Habitability of a large ghost crater in Chryse Planitia, Mars. In International Conference: Exploring Mars Habitability, Lisbon, Portugal.

Oehler, D.Z. and Allen, C.C. (2012a) Focusing the search for biosignatures on Mars: facies prediction with an example from Acidalia Planitia. In Sedimentary Geology of Mars, SEPM Special Publication 102, edited by J.P. Grotzinger and R.E. Milliken, Society for Sedimentary Geology, Tulsa, OK, pp 183-194.

Oehler, D.Z. and Allen, C.C. (2012b) Giant polygons and mounds in the lowlands of Mars: signatures of an ancient ocean? Astrobiology 12:601-615.

Oehler, D.Z. and Sternberg, B.K. (1984) Seepage-induced anomalies, "false" anomalies, and implications for electrical prospecting. Am Assoc Pet Geol Bull 68:1121-1145.

Oehler, D.Z., Allen, C.C., and McKay, D. (2005) Impact metamorphism of subsurface organic matter on Mars: a potential source for methane and surface alteration [abstract 1025]. In $36^{\text {th }}$ Lunar and Planetary Science Conference, Lunar and Planetary Institute, Houston.

Okubo, C.H. (2014) Bedrock Geologic and Structural Map through the Western Candor Colles Region of Mars, U.S. Geological Survey Scientific Investigations Map 3309, 
pamphlet 8 p., scale 1:18,000. Available online at https:// dx.doi.org/10.3133/sim3309

Okubo, C.H. (2016) Morphologic evidence of subsurface sediment mobilization and mud volcanism in Candor and Coprates Chasmata, Valles Marineris, Mars. Icarus 269:23-37.

Okumura, F. and Mimura, K. (2011) Gradual and stepwise pyrolyses of insoluble organic matter from the Murchison meteorite revealing chemical structure and isotopic distribution. Geochim Cosmochim Acta 75:7063-7080.

Osinski, G.R. and Spray, J.G. (2005) Tectonics of complex crater formation as revealed by the Haughton impact structure, Devon Island, Canadian High Arctic. Meteorit Planet Sci 40:1813-1834.

Osinski, G.R., Lee, P., Spray, J.G., Parnell, J., Lim, D.S.S., Bunch, T.E., Cockell, C.S., and Glass, B. (2005) Geological overview and cratering model for the Houghton impact structure, Devon Island, Canadian High Arctic. Meteorit Planet Sci 40:1759-1776.

Oze, C. and Sharma, M. (2005) Have olivine, will gas: serpentinization and the abiogenic production of methane on Mars. Geophys Res Lett 32, doi:10.1029/2005GL022691.

Oze, C., Jones, L.C., Goldsmith, J.I., and Rosenbauer, R.J. (2012) Differentiating biotic from abiotic methane genesis in hydrothermally active planetary surfaces. Proc Natl Acad Sci USA 109:9750-9754.

Pan, L., Ehlmann, B.L., Carter, J., and Ernst, C.M. (2016) The stratigraphy of the northern plains inferred from mineralogy of impact craters [abstract 2338]. In $47^{\text {th }}$ Lunar and Planetary Science Conference, Lunar and Planetary Institute, Houston.

Parnell, J. and Lindgren, P. (2006) Survival of reactive carbon through meteorite impact melting. Geology 34:1029-1032.

Parnell, J., Osinski, G.R., Lee, P., Green, P.F., and Baron, M.J. (2005) Thermal alteration of organic matter in an impact crater and the duration of past impact heating. Geology 33:373-376.

Passey, Q.R., Bohacs, K., Esch, W.L., Klimentidis, R., and Sinha, S. (2010) From oil-prone source rock to gas-producing shale reservoir-geologic and petrophysical characterization of unconventional shale gas reservoirs. In International Oil and Gas Conference and Exhibition in China, 8-10 June, Beijing, China, Society for Sedimentary Geology, Tulsa, OK, doi:10.2118/131350-MS.

Petitjean, M., Clifford, S.M., and Costard, F. (2014) Geomorphologic evidence for the presence of massive ground ice in the northern plains of Mars [abstract 2794]. In 45 ${ }^{\text {th }}$ Lunar and Planetary Science Conference, Lunar and Planetary Institute, Houston.

Philp, R.P. and Crisp, P.T. (1982) Surface geochemical methods used for oil and gas prospecting: a review. J Geochem Explor 17:1-34.

Pondrelli, M., Rossi, A.P., Ori, G.G., Van Gasselt, S., Praeg, D., and Ceramicola, S. (2011) Mud volcanoes in the geologic record of Mars: the case of Firsoff Crater. Earth Planet Sci Lett 304:511-519.

Portnov, A., Smith, A.J., Mienert, J., Cherkashov, G., Rekant, P., Semenov, P., Serov, P., and Vanshtein, B. (2013) Offshore permafrost decay and massive seabed methane escape in water depths $>20 \mathrm{~m}$ at the South Kara Sea shelf. Geophys Res Lett 40:3962-3967.

Poulet, F., Gomez, C., Bibring, J.-P., Langevin, Y., Gondet, B., Pinet, P., Belluci, G., and Mustard. J. (2007) Martian surface mineralogy from Observatoire pour la Minéralogie, l'Eau, les Glaces et l'Activité on board the Mars Express spacecraft (OMEGA/MEx): Global mineral maps. J Geophys Res 112, doi:10.1029/2006JE002840.
Quigley, T.M. and Mackenzie, A.S. (1988) The temperature of oil and gas formation in the sub-surface. Nature 333:549-552.

Rice, J.W., Jr., and Edgett, K.S. (1997) Catastrophic flood sediments in Chryse basin, Mars, and Quincy basin, Washington: application of sandar facies model. J Geophys Res 102:4185-4200.

Robledo-Martinez, A., Sobral, H., and Ruiz-Meza, A. (2012) Electrical discharges as a possible source of methane on Mars: lab simulation. Geophys Res Lett 39, doi:10.1029/ 2012 GL053255.

Rodríguez, J.A.P., Sasaki, S., Dohm, J.M., Tanaka, K.L., Strom, B., Kargel, J.S., Kuzmin, R., Miyamoto, H., Spary, J.G., Faíren, A.G., Komatsu, G., Kurita, K., and Baker, V.R. (2005) Control of impact crater fracture systems on subsurface hydrology, ground subsidence, and collapse, Mars. $J$ Geophys Res 110, doi:10.1029/2004JE002365.

Rodríguez, J.A.P., Tanaka, K.L., Kargel, J.S., Dohm, J.M., Kuzmin, R., Fairén, A.G., Sasaki, S., Komatsu, G., SchulzeMakuch, D., and Jianguo, Y. (2007) Formation and disruption of aquifers in southwestern Chryse Planitia, Mars. Icarus 191:545-567.

Rogers, A.D., Christensen, P.R., and Bandfield, J.L. (2005) Compositional heterogeneity of the ancient martian crust: analysis of Ares Vallis bedrock with THEMIS and TES data. J Geophys Res 110, doi:10.1029/2005JE002399.

Roos-Serote, M., Atreya, S.K., Webster, C.R., and Mahaffy P.R. (2016) Cometary origin of atmospheric methane variations on Mars unlikely. J Geophys Res: Planets 121, doi:10 .1002/2016JE005076.

Rossi, A.P., Neukum G., Pondrelli, M., Van Gasselt, S., Zegers, T., Hauber, E., Chicarro, A., and Foing, F. (2008) Large-scale spring deposits on Mars? J Geophys Res 113, doi:10.1029/ 2007JE003062.

Rubin, D.M, Faíren, A., Martínez-Frías, J., Frydenvang, J., Gasnault, O., Galfenbaum, G., Goetz, W., Grotzinger, J.P., Le Mouélic, S., Mangold, N., Newsom, H., Oehler, D.Z., Rapin, W., Schieber, J., and Weins, R.C. (2017) Fluidized-sediment pipes in Gale Crater, Mars, and possible Earth analogs. Geology 45:7-10.

Ruff, S.W. (2004) Spectral evidence for zeolite in the dust on Mars. Icarus 168:131-143.

Ruff, S.W. and Farmer, J.D. (2016) Silica deposits on Mars with features resembling hot spring biosignatures at El Tatio in Chile. Nat Commun 7, doi:10.1038/ncomms13554.

Ruff, S.W., Farmer, J.D., Calvin, W.M., Herkenhoff, K.E., Johnson, J.R., Morris, R.V., Rice, M.S., Arvidson, R., Bell, J.F., III, Christensen, P.R., and Squyres, S.W. (2011) Characteristics, distribution, origin, and significance of opaline silica observed by the Spirit rover in Gusev Crater, Mars. $J$ Geophys Res 116, doi:10.1029/2010JE003767.

Russell, P.S. and Head, J.W. (2003) Elysium-Utopia flows as mega-lahars: a model of dike intrusion, cyrosphere cracking, and water-sediment release. J Geophys Res 108, doi:10.1029/ 2002JE001995.

Salguero-Hernández, E., Urrutia-Fucugauchi, J., and RamírezCruz, L. (2010) Fracturing and deformation in the Chicxulub Crater-complex trace analysis of instantaneous seismic attributes. Revista Mexicana de Ciencias Geológicas 27:175-184.

Salvatore, M.R. and Christensen, P.R. (2014a) Evidence for widespread aqueous sedimentation in the northern plains of Mars. Geology 42:423-426.

Salvatore, M.R. and Christensen, P.R. (2014b) On the origin of the Vastitas Borealis Formation in Chryse and Acidalia Planitiae, Mars. J Geophys Res: Planets 119:2437-2456. 
Salvatore, M.R., Mustard, J.F., Wyatt, M.B., and Murchie, S.L. (2010) Definitive evidence of Hesperian basalt in Acidalia and Chryse planitiae. J Geophys Res 115, doi:10.1029/ 2009JE003519.

Schoell, M., editor. (1988) Origins of methane in the Earth. Chem Geol 71(1-3):1-265.

Schrenk, M.O., Brazelton, W.J., and Lang, S.Q. (2013) Serpentinization, carbon, and deep life. Rev Mineral Geochem 75:575-606.

Schuerger, A.C., Moores, J.E., Clausen, C.A., Barlow, N.G., and Britt, D.T. (2012) Methane from UV-irradiated carbonaceous chondrites under simulated martian conditions. $J$ Geophys Res 117, doi:10.1029/2011JE004023.

Schulte, M.D., Blake, D.F., Hoehler, T.M., and McCollom, T. (2006) Serpentinization and its implications for life on the early Earth and Mars. Astrobiology 6:364-376.

Schumacher, D. (1996) Hydrocarbon-induced alteration of soils and sediments, hydrocarbon migration and its near-surface expression. In Hydrocarbon Migration and Its Near-Surface Expression, AAPG Memoir 66, edited by D. Schumacher and M.A. Abrams, PennWell Publishing, Tulsa, OK, pp 71-89.

Schumacher, S. and Breuer, D. (2007) An alternative mechanism for recent volcanism on Mars. Geophys Res Lett 34, doi:10.1029/2007GL030083.

Schwenzer, S.P. and Kring., D.A. (2009a) Impact-generated hydrothermal systems: capable of forming phyllosilicates on Noachian Mars. Geology 37:1091-1094.

Schwenzer, S.P. and Kring, D.A. (2009b) Impact-generated hydrothermal alteration on Early Mars in presence of $\mathrm{CO}_{2}$. Meteorit Planet Sci 44:A188.

Schwenzer, S.P., Abramov, O., Allen, C.C., Clifford, S.M., Cockell, C.S., Filiberto, J., Kring, D.A., Lasue, J., McGovern, P.J., Newsom, H.E., Treiman, A.H., Vaniman, D.T., and Wiens, R.C. (2012) Puncturing Mars: how impact craters interact with the martian cryosphere. Earth Planet Sci Lett 335-336:9-17.

Scott, H.P., Hemley, R.J., Mao, H.D., Herschbach, R., Fried, L.E., Howard, W.M., and Bastea, S. (2004) Generation of methane in the Earth's mantle: in situ high pressure-temperature measurements of carbonate reduction. Proc Natl Acad Sci USA 101:14023-14026.

Seewald, J.S. (2003) Organic-inorganic interactions in petroleum-producing sedimentary basins. Nature 426:327-333.

Seewald, J.S., Benitez-Nelson, B.C., and Whelan, J.K. (1998) Laboratory and theoretical constraints on the generation and composition of natural gas. Geochim Cosmochim Acta 62:1599-1617.

Sephton, M.A. (2002) Organic compounds in carbonaceous meteorites. Nat Prod Rep 19:292-311.

Siebach, K.L. and Grotzinger, J.P. (2014) Volumetric estimates of ancient water on Mount Sharp based on boxwork deposits, Gale Crater, Mars. J Geophys Res 119:189-198.

Skinner, J.A., Jr., and Mazzini, A. (2009) Martian mud volcanism: terrestrial analogs and implications for formational scenarios. Mar Pet Geol 26:1866-1878.

Skinner, J.A., Jr. and Tanaka, K.L. (2007) Evidence for and implications of sedimentary diapirism and mud volcanism in the southern Utopia highland-lowland boundary plain, Mars. Icarus 186:41-59.

Sleep, N.H. (1994) Martian plate tectonics. J Geophys Res 99:5639-5655.

Smith, N.J.P., Sheperd, T.J., Styles, M.T., and Williams, G.M. (2005) Hydrogen exploration: a review of global hydrogen accumulations and implications for prospective areas in NW Europe. In Petroleum Geology: North-West Europe and Global Perspectives, Proceedings of the $6^{\text {th }}$ Petroleum Geology Con- ference, edited by A.G. Doré and B.A. Vining, Geological Society, London, pp 349-358.

Soare, R.J., Conway, S.J., Dohm, J.M., and El-Maarry, M.R. (2014) Possible open-system (hydraulic) pingos in and around the Argyre impact regions of Mars. Earth Planet Sci Lett 398:25-36.

Soare, R.J., Conway, S.J., Gallagher, C., and Dohm, J.M. (2017) Ice-rich (periglacial) vs icy (glacial) depressions in the Argyre regions, Mars: a proposed cold-climate dichotomy of landforms. Icarus 282:70-83.

Spagnuolo, M.G., Rossi, A.P., Hauber, E., and Van Gasselt, S. (2011) Recent tectonics and subsidence on Mars: hints from Aureum Chaos. Earth Planet Sci Lett 312:13-21.

Spohn, T., Grott, M., Knollenberg, J., Zoest, T.V., Kargl, G., Smrekar, S.E., Banerdt, W.B., and Hudson, T.L., HP ${ }^{3}$ instrument team. (2012) InSight: measuring the martian heat flow using the Heat Flow and Physical Properties package $\left(\mathrm{HP}^{3}\right)$ [abstract 1445]. In $43^{\text {rd }}$ Lunar and Planetary Science Conference, Lunar and Planetary Institute, Houston.

Stevens, A., Patel, M.R., and Lewis, S.R. (2015) Numerical modelling of the transport of trace gases including methane in the subsurface of Mars. Icarus 250:587-594.

Stevens, A.H., Patel, M.R., and Lewis, S.R. (2017) Modelled isotopic fractionation and transient diffusive release of methane from potential subsurface sources on Mars. Icarus 281:240-247.

Stolper, D.A., Martini, A.M., Clog, M., Douglas, P.M., Shusta, S.S., Valentine, D.L., Sessions, A.L., and Eiler, J.M. (2015) Distinguishing and understanding thermogenic and biogenic sources of methane using multiply substituted isotopologues. Geochim Cosmochim Acta 161:219-247.

Stuurman, C., Osinski, G.R., Holt, J.W., Levy, J.S., Brothers, T.C., Kerrigan, M.C., and Campbell, B.A. (2016) Sharad detection and characterization of subsurface water ice deposits in Utopia Planitia, Mars. Geophys Res Lett 43, doi:10 .1002/2016GL070138.

Summers, M.E., Lieb, B.J., Chapman, E., and Yung, Y.L. (2002) Atmospheric biomarkers of subsurface life on Mars. Geophys Res Lett 29, doi:10.1029/2002GL015377.

Tanaka, K.L. (1997) Sedimentary history and mass flow structures of Chryse and Acidalia Planitiae, Mars. J Geophys Res 102:4131-4150.

Tanaka, K.L. (2005) Geology and insolation-driven climatic history of Amazonian north polar materials on Mars. Nature 437:991-994.

Tanaka, K.L., Joyal, T., and Wenker, A. (2000) The Isidis Plains Unit, Mars: possible catastrophic origin, tectonic tilting, and sediment loading [abstrct 2023]. In $31^{\text {st }}$ Lunar and Planetary Science Conference, Lunar and Planetary Institute, Houston.

Tanaka, K.L., Skinner, J.A., Jr., Hare, T.M., Joyal, T., and Wenker, A. (2003) Resurfacing history of the Northern Plains of Mars based on geologic mapping of Mars Global Surveyor data. J Geophys Res 108, doi:10.1029/2002JE001908.

Tanaka, K.L., Skinner, J.A., Jr., and Hare, T.M. (2005) Geologic Map of the Northern Plains of Mars, U.S. Geological Survey Science Investigations Map 2888, scale 1:15,000,000. Available online at https://pubs.usgs.gov/sim/2005/2888

Tanaka, K.L., Rodríguez, J.A.P., Skinner, J.A., Jr., Mourke, M.C., Fortezzo, C.M., Herkenhoff, K.E., Kolb, E.J., and Okubo, C.H. (2008) North polar region of Mars: advances in stratigraphy, structure, and erosional modification. Icarus 196:318-358.

Taylor, J., Teanby, N.A., and Wookey, J. (2013) Estimates of seismic activity in the Cerberus Fossae region of Mars. $J$ Geophys Res: Planets 118:2570-2581. 
Tewelde, Y. and Zuber, M.T. (2013) Determining the fill thickness and densities of Mars' northern lowlands [abstract 2151]. In $44^{\text {th }}$ Lunar and Planetary Science Conference, Lunar and Planetary Institute, Houston.

Thomson, B.J. and Head, J.W., III. (2001) Utopia basin, Mars: characterization of topography and morphology and assessment of the origin and evolution of basin internal structures. J Geophys Res 106:23209-23230.

Tissot, B.P. and Welte, D.H. (1978) Petroleum Formation and Occurrence, Springer-Verlag, Berlin.

Treiman, A.H., Dyer, D.M., McCanta, M., Noble, S.K., and Pieters, C.M. (2007) Martian dunite NWA 2737: petrographic constraints on geological history, shock events, and olivine color. J Geophys Res 112, doi:10.1029/2006JE002777.

Tung, H.C., Bramall, N.E., and Price, P.B. (2005) Microbial origin of excess methane in glacial ice and implications for life on Mars. Proc Natl Acad Sci USA 102:18292-18296.

Vetterlein, J. and Roberts, G.P. (2010) Structural evolution of the Northern Cerberus Fossae graben system, Elysium Planitia, Mars. J Struct Geol 32:394-406.

Viscardy, S., Daerden, F., and Neary, L. (2016) Formation of layers of methane in the atmosphere of Mars after surface release. Geophys Res Lett 43:1868-1875.

Watters, T.R. (2003a) Lithospheric flexure and the origin of the dichotomy boundary on Mars. Geology 31:271-274.

Watters, T.R. (2003b) Thrust faults along the dichotomy boundary in the eastern hemisphere of Mars. J Geophys Res 108, doi:10.1029/2002JE001934.

Wang, P., Zhang, X., Zhu, Y., Li, B., Huang, X., Pang, S., Zhang, S., Lu, C., and Xiao, R. (2014) Effect of permafrost properties on gas hydrate petroleum system in the Qilian Mountains, Qinghai, Northwest China. Environ Sci Processes Impacts 16:2711-2720.

Wang, W., Wang, S., Ma, X., and Gong, J. (2011) Recent advances in catalytic hydrogenation of carbon dioxide. Chem Soc Rev 40:3703-3727.

Webster, C.R., Mahaffy, P.R., Atreya, S.K., Flesch, G.J., Mischna, M.A., Meslin, P.Y., Farley, K.A., Conrad, P.G., Christensen, L.E., Pavlov, A.A., Martín-Torres, J., Zorzano, M.P., McConnochie, T.H., Owen, T., Eigenbrode, J.L., Glavin, D.P., Steele, A., Malespin, C.A., Archer, P.D., Jr., Sutter, B., Coll, P., Freissinet, C., McKay, C.P., Moores, J.E., Schwenzer, S.P., Bridges, J.C., Navarro-Gonzalez, R., Gellert, R., Lemmon, M.T.; MSL Science Team. (2015) Mars methane detection and variability at Gale Crater. Science 247:415-417.

Webster, C.R., Mahaffy, P.R., and Atreya, S.K. (2016) Low background levels of Mars methane at Gale Crater indicate seasonal cycle: updated results from TLS-SAM on Curiosity [abstract P23B-2170]. In AGU Fall Meeting, American Geophysical Union, Washington, DC.

Welhan, J.A. (1988) Origins of methane in hydrothermal systems. Chem Geol 71:183-198.

Wellsbury, P., Goodman, K., Barth, T., Cragg, B.A., Barnes, S.P., and Parkes, R.J. (1997) Deep marine biosphere fuelled by increasing organic matter availability during burial and heating. Nature 388:573-576.
Whiticar, M.J. (1999) Carbon and hydrogen isotope systematics of bacterial formation and oxidation of methane. Chem Geol 161:291-314.

Whiticar, M.J., Faber, E., and Schoell, M. (1986) Biogenic methane formation in marine and freshwater environments: $\mathrm{CO}_{2}$ reduction versus acetate fermentation-isotope evidence. Geochim Cosmochim Acta 50:693-709.

Wilhems, D.E. and Squyres, S.W. (1984) The martian hemispheric dichotomy may be due to a giant impact. Nature 309:138-140.

Williams, J.-P., Dohm, J.M., Soare, R.J., Flahaut, J., Lopes, R.M.C., Pathare, A.V., Fairén, A.G., Schulze-Makuch, D., and Buczkowski, D.L. (2017) Long-lived volcanism within Argyre basin, Mars. Icarus 293:8-26.

Withers, P. and Neumann, G.A. (2001) Enigmatic northern plains of Mars. Nature 410, doi:10.1038/35070640.

Wordsworth, R., Kalugina, Y., Lokshtanov, S., Vigasin, A., Ehlmann, B., and Head, J. (2017) Transient reducing greenhouse warming on early Mars. Geophys Res Lett 4:665-671.

Wycherley, H.L., Parnell, J., and Baron, M.L. (2004) Survival of organic matter after high temperature events (meteorite impacts, igneous intrusions) [abstract 1149]. In $35^{\text {th }}$ Lunar and Planetary Science Conference, Lunar and Planetary Institute, Houston.

Yin, A. (2012) Structural analysis of the Valles Marineris fault zone: possible evidence for large-scale strike-slip faulting on Mars. Lithosphere 4:286-330.

Address correspondence to: Dorothy Z. Oehler

Planetary Science Institute 1700 East Fort Lowell Suite 106 Tucson, AZ 85719

E-mail: doehler@psi.edu

Submitted 1 February 2017 Accepted 14 May 2017

Abbreviations Used
CRISM $=$ Compact Reconnaissance Imaging
Spectrometer for Mars
CTX $=$ Context Camera
FTT $=$ Fischer-Tropsch-type
HiRISE $=$ High Resolution Imaging Science Experiment
IDPs $=$ interplanetary dust particles
MOLA $=$ Mars Orbiter Laser Altimeter
OMEGA $=$ Observatoire pour la Minéralogie, l'Eau,
les Glaces, et l'Activité
QCDs $=$ quasi-circular depressions
TES $=$ Thermal Emission Spectrometer
THEMIS $=$ Thermal Emission Imaging System
ULM $=$ Uzboi-Ladon-Morava

